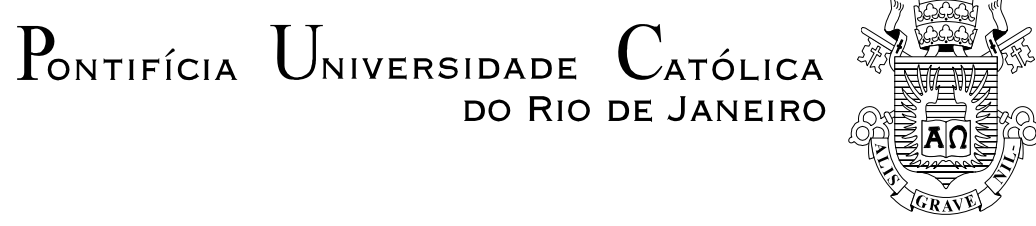

Elza Maria Mussi Ibrahim

Manicômio Judiciário:

o testemunho de um olhar vivido

Dissertação de Mestrado

Dissertação apresentada como requisito parcial para obtenção do grau de Mestre pelo Programa de Pósgraduação em Psicologia do Departamento de Psicologia da PUC-Rio.

Orientadora: Profa. Junia de Vilhena

Rio de Janeiro

Novembro de 2012 


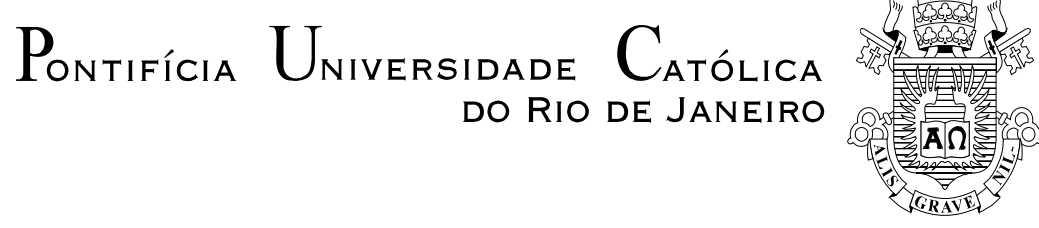

Elza Maria Mussi Ibrahim

\section{Manicômio Judiciário: o testemunho de um olhar vivido}

Tese apresentada como requisito parcial para obtenção do grau de Doutor pelo Programa de Pós-Graduação em Psicologia Clínica do Departamento de Psicologia do Centro de Teologia e Ciências Humanas da PUC-Rio. Aprovada pela Comissão Examinadora abaixo assinada.

Profa. Junia de Vilhena Orientadora Departamento de Psicologia - PUC-Rio

Profa. Maria Helena Rodrigues Navas Zamora Departamento de Psicologia - PUC-Rio

Prof. Luis Antônio dos Santos Baptista Departamento de Psicologia - UFF

Profa. Denise Berruezo Portinari Coordenadora Setorial de Pós-Graduação

e Pesquisa do Centro de Teologia e Ciências Humanas - PUC-Rio

Rio de Janeiro, 06 de novembro de 2012. 
Todos os direitos reservados. É proibida a reprodução total ou parcial do trabalho sem autorização da autora, da orientadora e da universidade.

\section{Elza Maria Mussi Ibrahim}

Psicóloga e Bacharel em Psicologia pela Pontificia Universidadedo Rio de Janeiro. Especialista em Psicologia Jurídica. Possui experiência na área de Psicologia Clínica e de Saúde Mental.

Ficha Catalográfica

Ibrahim, Elza Maria Mussi

Manicômio judiciário: o testemunho de um olhar vivido / Elza Maria Mussi Ibrahim; orientadora: Junia de Vilhena. 2012.

$$
143 \mathrm{f.} ; 30 \mathrm{~cm}
$$

Dissertação (mestrado) - Pontifícia Universidade Católica do Rio de Janeiro, Departamento de Psicologia, 2012.

Inclui bibliografia

1. História - Teses. 2. Manicômio judiciário. 3. Loucocriminoso. 4. Relações de saber/poder. 5. Jogos de verdade. I. Vilhena, Junia de. II. Pontifícia Universidade Católica do Rio de Janeiro. Departamento de Psicologia. III. Título. 
Aos meus pais Rachel e Michel por seu amor incondicional. 


\section{Agradecimentos}

À Junia de Vilhena, minha orientadora, por seu acolhimento e constante incentivo.

Ao meu querido e doce afilhado Cesinha, pela sua paciência e compreensão nos meus mais acalorados momentos de intolerância e de irritação...

Ao meu irmão Cesar Ibrahim que, a seu modo, sempre torceu por mim.

A Luiz Fernando Chazan, por ter me encorajado desde o início.

À amiga Angela Coutinho, uma das responsáveis pelo meu encantamento por Michel Foucault.

À Heliana Conde, pela disponibilidade e generosidade de seus ensinamentos.

Às amigas Leily e Cybele, e à minha prima Julita, pela prontidão irrestrita às inúmeras dúvidas que me acercaram durante este período.

A todos os meus amigos que me acompanharam nessa caminhada, demonstrando sua preocupação e carinho.

E, finalmente, aos meus tão especiais pacientes do Manicômio Judiciário, que me confirmaram a ideia de se poder olhar para loucura sem temê-la tanto! 


\section{Resumo}

Ibrahim, Elza; Vilhena, Junia de (Orientadora). Manicômio Judiciário: o testemunho de um olhar vivido. Rio de Janeiro, 2012. 143p. Dissertação de Mestrado - Departamento de Psicologia, Pontifícia Universidade Católica do Rio de Janeiro.

Esta dissertação tem como objetivo problematizar o lugar em que o 'loucocriminoso' foi inserido ao longo de todos esses séculos dentro da história da Psiquiatria. Preocupamo-nos em mostrar quem é este sujeito e o local onde ele vive encarcerado: o manicômio judiciário. Tentamos trazer à discussão os dispositivos utilizados, tanto pela Psiquiatria quanto pelo Direito, para classificar e normatizar este sujeito considerado inimputável. Para tanto, guiamo-nos pelas ideias de Michel Foucault, especialmente àquelas que dizem respeito às 'relações de saber/poder’ e aos ‘jogos de verdade’ que permeiam o campo do instituído. Enfatizamos a necessidade de uma atitude crítica por parte do profissional que opera no campo da saúde, assim como alertamos para a importância de se criar ações de resistência frente àquilo que é imposto e considerado como naturalizado pela instituição mesma. Por fim, nos voltamos ao 'louco-criminoso' internado no Manicômio Judiciário para tão somente ouvir as suas histórias.

\section{Palavras-chave}

Manicômio Judiciário; louco-criminoso; relações de saber/poder; jogos de verdade. 


\section{Abstract}

Ibrahim, Elza; Vilhena, Junia de (Advisor). A psychiatric-penal institution: the witness to a lived look. Rio de Janeiro, 2012. 143p. MSc. Dissertation - Departamento de Psicologia, Pontifícia Universidade Católica do Rio de Janeiro.

This dissertation has the objective of problematizing how the criminally insane were viewed along the years within the history of Psychiatry. We want to show who he is, how and where he is incarcerated: the prison for the criminally insane known in Brazil as 'Manicômio Judiciário'. We attempt to bring to the discussion the mechanisms used by Psychiatry and by Law to classify and normatize this human being considered not to be regularly punished. To do so, we are guided by Michel Foucault`s ideas, especially those related to the 'knowledge/power relationships' and 'the truth games' which permeate the institutionalized field. We emphasize the need for a critical attitude by the professional who operates in the health arena and also signal to the importance of creating resistance actions to what it is imposed and considered natural by the institution itself. Finally, we approach the 'criminally insane' in the 'Manicôminio Judicário’ with the mere intention of listening to their stories.

\section{Keywords}

Penal-psychiatric institution; criminally insane; relationships knowledge/power, the truth games. 


\section{Sumário}

1. Introdução

2. Manicômio Judiciário: o final da linha? 16

2.1. Que lugar é esse? 16

2.2. Quem são essas pessoas? $\quad 21$

2.2.1. Da concepção trágica à concepção crítica da loucura: do louco ao doente mental 21

2.2.2. Surge uma nova invenção: o “crime de loucura” 29

2.3. Quem gerencia tudo isso? 33

2.3.1. O casamento do Direito com a Psiquiatria: gera-se o inimputável 33

2.3.2. O surgimento da Criminologia e suas confusas terminologias 36

3. Porque Foucault? $\quad 50$

3.1. O método arqueogenealógico de Michel Foucault 51

3.2. Os pilares foucaultianos e a questão do sujeito $\quad 54$

3.2.1. Jogos de saber, Jogos de poder e Resistência 63

3.2.2. Jogos de Verdade: 'Porque sempre foi assim'... 69

3.3. O campo do instituído: dispositivos e especialistas 74

$\begin{array}{ll}\text { 3.3.1. Os reis-ubus e a rede maquiada de cientificidade } & 74\end{array}$

4. O que fazem os operadores da saúde? Reflexões sobre o saber 'psi' e Resistência $\quad 85$

4.1. Como jogam os operadores da saúde? 86

4.2. Estratégias de Resistência: procurando saídas na prática 95

$\begin{array}{ll}\text { 5. Os pequenos grandes homens } & 109\end{array}$

5.1. O silêncio dos sujeitados 109

5.2. Passeando pela História Oral na companhia de Foucault, Portelli e Coutinho 115

5.3. Com a palavra, o louco! 125

6. Considerações finais 130

7. Referências bibliográficas 136 


\section{1 \\ Introdução}

Quando eu tinha os meus nove ou dez anos de idade, costumava ouvir que não deveríamos passar por aquela rua; ou ao menos, evitar aquele lado da calçada ou ainda, em último caso, desviar terminantemente o olhar daquele estranho casarão... Com um misto de curiosidade, temor e atração, via-me sempre que podia escapar do controle dos mais velhos -, passando em frente àquela misteriosa casa.

Ela era um tanto recuada da calçada principal, tinha um grande muro de grades e um jardim que a antecedia. Ao fundo, lá se impunha ela: branca, com janelas fortemente gradeadas, dois andares e, em volta, algumas árvores frondosas que acabavam por compor uma cena que me amedrontava e, ao mesmo tempo, me incitava, obrigando-me a diminuir os passos naquelas escapulidas providenciais. Não raro, ouviam-se gritos assustadores, como se estivessem pedindo socorro e, para mim, reais ou não, eu via vultos por detrás daquelas janelas.

Para a grande maioria dos adultos que me rodeavam, os habitantes do casarão eram 'não-pessoas', eram o 'estranho', o bizarro. Não tinham nome, não tinham passado nem futuro, enfim, não tinham história. Quem seriam eles, afinal?...

Àquela época, eu ainda não conseguia entender exatamente quem eram tais pessoas. A única coisa que eu sabia era que, para os adultos, aquela rua era considerada proibida, maldita, como se, ao passarmos por ela, a loucura pudesse nos contaminar...

Esta pesquisa se inicia com uma indagação: teria a concepção a respeito da loucura se modificado ao longo desses mais de 50 anos? Seriam os manicômios da atualidade diferentes dos sanatórios de então? Terão sido aqueles gritos do passado silenciados em nossos dias?

A minha aproximação e meu interesse pela loucura teve aí os seus primórdios... Mas a ideia de problematizar a questão acerca do sujeito 
inimputável $^{1}$ surgiu, de fato, a partir da minha vivência nos quase trinta anos trabalhados numa instituição psiquiátrico-penal, o Manicômio Judiciário, que custodia indivíduos portadores de um duplo estigma, qual seja, o do crime e o da loucura.

A fundamentação teórica desse trabalho apresenta-se ancorada no pensamento filosófico de Michel Foucault com referência, sobretudo, às relações de saber/poder, aos jogos de verdade, e ao fenômeno da resistência presente no campo social. Acreditamos ser Michel Foucault, um dos grandes pensadores da contemporaneidade, o autor que mais tenha tratado e contribuído de forma efetiva para a produção de novas maneiras de se olhar o instituído e de como resistir às suas injunções.

É sabido que, ao se trabalhar em instituições totais, o profissional corre o risco de se adaptar ao fenômeno da prisonização ${ }^{2}$ - conforme detecta Augusto Thompson (1976) - especialmente se ele lá permanece durante muitos anos. Neste caso, é comum observar-se uma forte identificação com a engrenagem institucional, o que lhe dificulta ter um olhar crítico e diferenciado em relação à mesma. E mais: essa maciça identificação produz uma atitude maquinal e automática de aceitação a tudo o que é dito e proposto pela instituição, levando o profissional 'psi' a acatar cegamente e a obedecer a determinadas regras e normas sem, ao menos, tentar ou se arriscar a questioná-las. Tanto aquele lá encarcerado quanto o que lá trabalha, acabam, por vezes, se adequando aos mecanismos e às estruturas que permeiam o campo institucional; tornam-se, via de regra, cronificados e engessados aos princípios e modelos já constituídos, o que lhes impossibilita a estranhar com o que está posto, a se surpreender com o naturalizado, a destruir as evidências, enfim, a reagir ao que lhes é estabelecido e determinado.

Acompanhando Foucault, acreditamos que, para se continuar a refletir, é imprescindível saber que podemos pensar sobre o que pensamos de forma diferente daquela que pensamos. Para tal, faz-se mister desconstruir o que há tanto

\footnotetext{
${ }^{1}$ Considera-se inimputável a pessoa que cometeu uma infração penal, porém, no momento do crime, era inteiramente incapaz de entender o caráter ilícito do fato ou de determinar-se de acordo com esse entendimento.

${ }^{2}$ O termo 'prisonização', cunhado por Donald Clemmer (1950), demarca os efeitos psicológicos do confinamento, indicando a adoção do modo de pensar, dos costumes e dos hábitos da cultura geral de quem vive enclausurado em penitenciárias e afins.
} 
se encontra instaurado, naturalizado e definido como verdadeiro, pois, segundo o autor, o que interessa não é 'a’ verdade, aquela que pretende distinguir o legítimo do ilegítimo, o falso do verdadeiro, o louco do não louco, mas a verdade como perspectiva histórica, como produto da contingência e do acaso.

Foucault nos fala de múltiplas verdades: para ele, não existe uma verdade absoluta, universal, mas tão somente jogos de verdade articulados a estratégias de saber/poder que dizem o que é falso e o que é verdadeiro. Interessa a ele o enfrentamento analítico do presente, o olhar crítico aos jogos de verdade que fixam determinadas regras e as adotam como incontestáveis. Tais verdades tornam-se absolutas e reinam incólumes no campo mesmo do instituído, podendo ser observadas através da prática dos dispositivos jurídico-psiquiátricos utilizados tanto pelo saber médico, quanto pelo saber da psicologia.

Esta dissertação não tem a intenção de denunciar a forma como é ou não visto ou como é ou não tratado o paciente internado nos nosocômios, nem tampouco em analisar o motivo que para lá os levou. O que pretendemos examinar e analisar neste trabalho - contrariamente à proposta de querer entender a loucura, a doença mental ou os dispositivos que permeiam a seara institucional é tentar compreender em que medida e em que condições de possibilidades estas práticas se produzem. Dito de outra maneira, o nosso objetivo é problematizar como certas práticas institucionais - que fazem parte da engrenagem médicajudiciária -, tornam-se estatutos de verdade com efeitos de prescrição do que deve e do que não deve ser feito; e de como este regime de práticas costuma ser aceito de forma tão natural e evidente, tanto pelos juristas quanto pelos profissionais 'psi' que atuam neste campo.

Queremos chamar a atenção para o fato de certos acontecimentos serem naturalmente acatados e acolhidos como pressupostos de verdade, sem qualquer estranhamento ou resistência. Queremos pontuar a importância, não de abjurar a lei ou as regras, mas em problematizar o estatuto das normatizações em prol do exercício de uma 'atitude crítica’ proposta, entre outros autores, por Didier Eribon (2004).

Parafraseando Foucault (1977 c), interessa-nos saber como o poder exercido sobre a loucura produz o discurso 'verdadeiro' da psiquiatria. Interessanos, tal como propõe a tese foucaultiana, romper com as evidências e com o que 
se apresenta naturalizado; saber como - a partir de quais valores ou de quais interesses jurídico-institucionais - atualiza-se certas práticas em regulamentos exatos e meticulosos. Sem dúvida, estas práticas estão a serviço de jogos de saber/poder que definem o que é normal ou anormal, perigoso ou não perigoso, medicável ou não medicável, passível ou não passível de ser punido. Com efeito, estes jogos de saber/poder não são privilégio nem direito apenas dos manicômios judiciários... Toda e qualquer instituição total os têm como prerrogativa.

São problematizações desse tipo que propomos levantar ao longo desta dissertação.

O trabalho está organizado em seis capítulos e nas suas respectivas subdivisões. O Capítulo 1 diz respeito à Introdução do trabalho, o Capítulo 6 refere-se às Considerações Gerais, e o Capítulo 7 às Referências bibliográficas. O corpo do texto compõe-se pelos demais capítulos.

No Capítulo 2 é descrita a estrutura física e geográfica do Manicômio Judiciário, como se estivéssemos fazendo um 'vôo rasante’ sobre ele: mostramos onde ele se encontra localizado, como é composto em seu espaço interior, qual a disposição das celas e enfermarias, das salas de atendimento, dos diferentes departamentos e seções, dos pátios e dos pontos estratégicos onde se situa o setor de segurança. Para melhor compreender o tipo de local a que estamos nos referindo, descrevemos e analisamos as suas principais características e funções, assim como a dinâmica de seu funcionamento. Em seguida dedicamo-nos a apresentar quem é este paciente inimputável encarcerado e separado do mundo através dos altos portões de ferro batido do $\mathrm{MJ}^{3}$ : trata-se daqueles chamados 'monstros', os quais as pessoas, de um modo geral, esperam encontrar por detrás desses portões. Para tal, faz-se mister explorar de que maneira o chamado louco foi transformado - ao longo dos séculos - em doente mental, ou seja, como se deu a passagem da concepção trágica à concepção crítica da loucura, problematizada por Michel Foucault em História da Loucura, escrita em 1961, considerada uma de suas mais ricas produções.

Ainda neste mesmo capítulo, analisamos como e porque a ciência psiquiátrica precisou criar a nosologia do 'crime de loucura' gerando-se, assim, o denominado ‘paciente inimputável'. Discutimos aí a loucura como anomalia,

\footnotetext{
${ }^{3}$ Sempre que for me referir ao Manicômio Judiciário do Rio de Janeiro, usarei a sigla MJ.
} 
como perigo, como algo que se deva manter isolado e afastado a fim de se proteger a sociedade (Foucault, 1974). Ao criar-se a figura do sujeito perigoso, do 'louco-criminoso’, foi antes preciso classificá-lo, catalogá-lo, enquadrá-lo dentro de determinados conceitos e de certas nosologizações. Para isso fez-se necessário a 'invenção' de dispositivos que pudessem, não só descrever tais figuras consideradas estranhas, como também de poder ordená-las: celebra-se, desse modo, o ‘casamento’ entre o direito e a psiquiatria, que surge como instrumento de transformação do louco em doente mental construindo-se, a partir daí, a figura - cunhada por Foucault (2001) - do 'médico-juiz', aquele que pretende tratar, julgando. Desta feita, com o surgimento da criminologia, surgem as noções de periculosidade e criam-se os dispositivos que pretendem controlar tal perigo e, para tal, é concebida uma modalidade jurídica denominada 'medida de segurança', a ser aplicada àqueles considerados inimputáveis. Fazemos também, ainda nesta primeira parte do trabalho, referência a alguns peritos-forense dos séculos XVIII/XIX que se baseavam na tese de que os comportamentos antissociais advinham de causas orgânicas.

Dedicamos o Terceiro Capítulo a justificar a nossa escolha por embasar este trabalho, preferencialmente, na rica obra de Michel Foucault. O filósofo e historiador francês é um dos autores da contemporaneidade que mais se preocupou em problematizar as relações de saber/poder, e de analisar como esses saberes se transformam em verdades universais e absolutas - através dos 'jogos de verdade' - presentes no campo e na prática institucional, quer seja nos manicômios como nas prisões.

Dando continuidade ao tema, lançamos luz sobre o terceiro pilar foucaultiano - considerando-se os dois primeiros como sendo, respectivamente, os 'jogos de saber/poder e os 'jogos de verdade'. Este terceiro pilar, diretamente imbricado às relações de saber/poder, diz respeito ao fenômeno da resistência entendida dentro da concepção foucaultiana como sendo um jogo de forças, a potência mesma que se insurge sobre as tentativas de dominação que partem do instituído. Sem dúvida, dentro desse ponto de vista, a resistência apresenta-se, através de suas estratégias, como possibilidade de transformação daquilo que está posto como definitivo e imutável, daquilo que se encontra naturalizado; a 
resistência passa a funcionar como um olhar crítico às normatizações e burocratizações do campo mesmo do instituído.

Em seguida passamos a estudar e a discutir os 'jogos de verdade', analisando criticamente algumas formas de dispositivos jurídico-psiquiátricos utilizadas no diagnóstico e na classificação do paciente inimputável. Para tanto, usamos como uma das principais referências, as obras Os Anormais (2001) e A verdade e as formas jurídicas (2005), este último composto por uma série de conferências proferidas por Michel Foucault na PUC/RJ, em maio de 1973, quando de sua visita ao Brasil. Nossa análise tem como alvo não somente discorrer e construir um olhar crítico sobre os dispositivos propriamente ditos, mas também investigar e pesquisar quem são aqueles que os produzem e que deles se utilizam: estamos nos referindo, destarte, aos chamados 'especialistas', ou como os denomina Michel Foucault (2001), os ‘reis-ubus’. Nossa intenção é, portanto, problematizar a questão de como é composta a prática desses profissionais e de sua rede maquiada de cientificidade.

São sobre eles, os operadores da saúde, que nos debruçamos no Capítulo 4 mostrando, inicialmente, como eles operam e como eles agem no interior da seara médica-jurídica. Segundo Foucault (1977 a), foi a partir da mecânica de poder, presente nas instituições totais, que se definiu a maneira como os corpos lá habitáveis deveriam ser distribuídos e analisados. E para que essas práticas fossem efetivamente exercidas, fez-se necessário não somente a invenção de técnicas de controle e de exame, como também a criação de profissionais capacitados para utilizar tais técnicas e saberes com o intuito de classificar e de nosologizar o 'louco-criminoso' e todos aqueles que ameaçavam a 'paz social'. Mas como nem tudo está perdido, analisamos - ainda nesse mesmo capítulo -, as condições de possibilidade de se encontrar saídas aos jogos de saber/poder vigentes no campo do instituído, indagando de onde deveriam surgir os focos de resistência: do paciente, do operador da saúde, ou de ambos?

Assim, procuramos nos deter sobre as possíveis estratégias de resistência e de que maneira o profissional 'psi' poderia exercer o seu poder para modificar o naturalizado, de modo a localizar as brechas, a fim de intervir na inação e na indiferença do estabelecido, “ali onde estão os pontos de resistência, onde há passagens possíveis”, como leciona Paul Veyne (2004, p.83). 
Finalmente, no Capítulo 5 nos dedicamos a dar a palavra àquele que quase nunca a tem: o louco. Iniciamos essa última parte trazendo a contribuição - além da já proporcionada por Michel Foucault -, de José Carlos Bruni (1989), autor igualmente estudioso e preocupado com o silêncio dos sujeitados.

Demonstramos, a partir de nossa vivência durante os quase trinta anos trabalhados no MJ, algumas formas - conscientes ou não -, de se fazer calar o sujeito encarcerado, especialmente o 'louco-criminoso', aquele considerado 'sujeito duplamente perigoso'. Por outro lado, felizmente, observamos que é possível se fazer passar a palavra a esses sujeitos invisíveis através de uma importante ferramenta utilizada como instrumento para fazer falar o silêncio: trata-se da chamada História Oral e de suas distintas maneiras de historiografar a verdade, e de entender a memória singular como forma de resistência à memória oficial.

Concluindo o capítulo, trazemos algumas histórias desses sujeitos que, via de regra, são nomeados de 'loucos-criminosos'.

Por último, no Capítulo 6, apresentamos as nossas Considerações Finais onde procuramos, a partir das problematizações aduzidas ao longo do trabalho, refletir sobre a possibilidade de se poder perceber com um olhar distinto, aqueles comumente considerados como sendo tão somente os 'monstros', os 'anormais': procuramos pontuar para a necessidade de se ouvir esses sujeitos que, na verdade, muito têm a nos dizer. 
2

\section{Manicômio Judiciário: o final da linha?}

\section{1}

\section{Que lugar é esse?}

“[...] Eu não sei se isso aqui é um hospital implantado numa cadeia, ou se é uma cadeia implantada num hospital". 4

Há 32 anos atrás eu atravessava o primeiro grande portão de grades do Hospital de Custódia e Tratamento Psiquiátrico Heitor Carrilho, hospital-penal do Departamento Penitenciário, subordinado ao Ministério da Justiça, parte integrante do antigo Complexo Penitenciário Frei Caneca, localizado no bairro do Estácio, Centro do Rio. Neste mesmo grande terreno encontravam-se integrados antes de serem implodidos -, quatro penitenciárias masculinas, uma penitenciária feminina e dois presídios ${ }^{5}$. No centro desse caldeirão humano situa-se, ainda hoje, o local destinado aos chamados 'loucos-criminosos': o então conhecido Manicômio Judiciário.

A entrada principal do Manicômio Judiciário é a mesma 'porta de entrada' de um dos acessos ao Morro de São Carlos, que se estende como uma meia-lua, por sobre e acima dele. Ao subirmos por este acesso um tanto estreito e íngreme não sem antes passar à porta do Batalhão de Choque da Polícia Militar -, nos deparamos com um prédio cinza, de dois andares, que antecede a entrada propriamente dita do pavilhão de internação. Neste primeiro prédio de dois andares encontra-se alocada a Direção do hospital e o serviço de Pericia Psiquiátrica Forense, dentre as demais seções administrativas. À saída deste primeiro prédio, passa-se por um curto, mas largo corredor a céu aberto, onde nos deparamos com um segundo grande portão, desta vez de ferro batido, sem possibilidade alguma de visão do que irá vir para além dele. Este segundo grande

\footnotetext{
${ }^{4}$ Relato de Anderson, paciente masculino internado no Manicômio Judiciário.

${ }^{5}$ Entende-se por penitenciária o local destinado àqueles que já foram condenados; o presídio geralmente de segurança máxima -, refere-se aos presos diferenciados, sob um maior tempo de condenação; enquanto que a cadeia destina-se aos presos provisórios.
} 
portão separa o mundo em dois lados: os que estão para aquém do portão de ferro, e os que estão encerrados - alguns, por toda a vida -, para dentro dele.

A ultrapassagem do segundo portão nos leva a um grande pátio aberto, margeado à direita, por um imenso muro de concreto e, à esquerda, por algumas árvores que quase escondem um pátio onde, uma vez por semana, os pacientes masculinos e femininos se encontram. Este pátio, por sua vez, se antepõe ao prédio do $\mathrm{SIF}^{6}$. O tratamento dispensado às pacientes femininas do Manicômio Judiciário (MJ) é claramente diferenciado daquele oferecido aos pacientes masculinos. É possível constatar esta afirmação quando se caminha pela parte externa do hospital: os pacientes masculinos circulam à vontade pelo pátio e têm livre acesso aos setores técnicos, sendo-lhes possível manter contato direto com os profissionais. Já as mulheres passam o tempo inteiro isoladas em suas celas individuais ou apenas caminhado, de um lado para o outro, ao longo das galerias. A elas tampouco é permitido integrar o grupo dos 'faxinas, enfrentando, na maior parte das vezes, grande resistência por parte da administração. Sendo assim, o setor feminino, além de estar localizado em um prédio isolado dos demais, mantém as pacientes femininas em total ociosidade, liberadas apenas a divagações e delírios.

Em frente ao SIF, nos deparamos com um grande prédio, onde se localiza, no primeiro andar, o setor técnico, composto pelas seções de psicologia, serviço social, psiquiatria, enfermagem e pelo setor de segurança, constituído por agentes penitenciários do sistema prisional. À direita, paralelamente a este pavilhão, há um novo pátio a céu aberto, uma quadra gradeada, onde acontecem os jogos de futebol de salão e, ao fundo pode-se avistar o Morro de São Carlos. Para além, sempre em frente, há um novo portão de ferro que, aberto, levaria muito antigamente, a um grande campo de futebol margeado por muros não tão altos assim, que não tivessem impedido, outrora, a fuga de alguns pacientes.

\footnotetext{
${ }^{6}$ O SIF (Setor de Internação Feminina) é constituído por cerca de 30 pacientes femininas que têm uma rotina diária distinta dos demais. A elas não é permitido sair das dependências do SIF, a não ser uma vez por semana, quando se encontram com os pacientes masculinos em um pátio vigiado por agentes de segurança. O setor é dividido em dois andares, cada qual com uma galeria composta por cerca de 20 celas individuais.

${ }^{7}$ Dá-se o nome de 'faxina' àquele paciente que possui uma função de trabalho dentro da instituição, como por exemplo, varrer as dependências externas do hospital, servir a mesa de refeição da equipe técnica, trabalhar no Gabinete da Direção, entre outras funções. Ser 'faxina' implica em ter mais liberdade de ir e vir, como também de obter alguns privilégios dentro da instituição.
} 
O pavilhão denominado de pavilhão-técnico tem dois andares: a entrada do primeiro andar é estreita, desaguando em um longo corredor, com pequenas salas ocupadas por diferentes setores - psicologia, enfermagem, psiquiatria, serviço social, entre outros -, em um número aproximado de doze salas. Dentre elas, existe uma, ironicamente denominada de ‘aquário’: trata-se de uma grande sala sem móveis, sem mesas nem cadeiras, mas apenas estreitos bancos de alvenaria que a margeiam. Aí acontecem - quando acontecem -, as reuniões de grupo com os pacientes. A denominação 'aquário’ se deve ao fato desta sala ter uma de suas grandes paredes vazadas por um vidro, através do qual os pacientes são vistos por qualquer um que passe à sua margem.

Mas não é somente através do ‘aquário’ que o paciente é controlado: há também as chamadas 'trancas', local destinado ao castigo dos pacientes que apresentam 'desvios da ordem ou da conduta'. Estas celas costumam ser pequenas e, a princípio, deveriam ser de uso individual; entretanto, dependendo da necessidade, são utilizadas por vários pacientes ao mesmo tempo. Durante certa época, inclusive, a 'tranca' destinou-se, não somente àqueles que apresentavam atitudes desviantes da norma, como também aos pacientes recém-internados, durante o período em que ficavam 'sob observação'. Estes espaços panópticos permitem que o indivíduo seja visto em qualquer canto da cela, do mesmo modo como as pacientes femininas podem ser observadas no interior de suas celas ou ‘cubículos', termo usualmente denominado por elas próprias.

Dentro desta disposição espacial, acentuam-se o controle e a vigilância em relação à vida do paciente, padrões e normas morais lhe são impostos, tentando, assim, adaptá-lo ao modelo determinado pelos profissionais lá alocados, que funcionam como os detentores do poder instituído. É preciso observar-se o paciente no seu ir-e-vir diário, em suas reações e movimentos, tal qual no modelo do Panóptico de Bentham, conceituado por Michel Foucault - autor que servirá de base para este estudo - como sendo

a figura arquitetural [...] cujo princípio é conhecido: na periferia uma construção em anel; no centro, uma torre; esta é vazada de largas janelas que se abrem sobre a face interna do anel; a construção periférica é dividida em celas, cada uma atravessando toda a espessura da construção; elas têm duas janelas, uma para o interior, correspondendo às janelas da torre; outra, que dá para o exterior, permite que a luz atravesse a cela de lado a lado. Basta então colocar um vigia na torre central, e em cada cela trancar um louco, um doente, um condenado, um operário ou um escolar. [...] Tantas jaulas, tantos pequenos teatros, em que cada ator está 
sozinho, perfeitamente individualizado e constantemente visível. O dispositivo panóptico organiza unidades espaciais que permitem ver sem parar e reconhecer imediatamente (FOUCAULT, 1977 a, p. 177).

Ora, esta prática de inspeção e policiamento pretende não apenas manter a ordem e a disciplina, mas, principalmente, produzir uma "indiferenciação e homogeneização, [...] que tende a evitar as tensões ou pelo menos mantê-las no nível mais baixo possível” (Enriquez, 1991). É preciso controlar a loucura e, para isso faz-se mister isolá-la, tal como se isolou a peste em fins do século XVII.

Mas falávamos do ‘aquário’: a disposição dos seus bancos de alvenaria impede um maior contato, não só entre os pacientes mesmo, como entre eles e a equipe de profissionais mantendo-os, fisicamente, afastados de tudo e de todos. O segundo andar, acima do 'aquário', foi sempre considerado um local 'desativado' a que ninguém tinha acesso. Chamavam-no de 'oupendol', em referência ao termo open door. Mas nunca se soube por quê...

Atrás e acima do pavilhão técnico ficam as chamadas 'enfermarias' dos pacientes masculinos, dispostas em três andares, cujo acesso é feito por largas e mal cheirosas rampas de concreto. Em cada andar há uma galeria com cerca de dez enfermarias; cada uma delas possui oito camas de alvenaria, e em cada enfermaria um banheiro sem porta e comum a todos, com apenas um cano, de onde pinga a água para o banho; por último, o 'boi' - um buraco no chão -, no lugar do vaso sanitário.

Do corredor da galeria pode-se avistar todo o interior de cada enfermaria. A intimidade e a privacidade são desrespeitadas sem o menor pudor no interior dessas instituições. Tanto as violações de privacidade, através da exposição física do paciente, como a censura de sua correspondência, as imposições de horários rígidos para alimentação e descanso, a obrigatoriedade do uso de uniforme, e outras tantas normas de conduta, impedem o indivíduo de manifestar o seu modo de ser, restando-lhe poucas maneiras de se expressar.

A esta contínua mutilação da identidade, Goffman (1974) denominou de 'mortificações do eu'. Contudo, existem outras maneiras de se mortificar o sujeito: muito frequentemente observam-se restrições à transmissão de informações, tais como, impedir que o paciente tenha acesso a seu laudo. O mesmo acontece em relação ao processo judicial: via de regra, o paciente é excluído de sua evolução. Mais uma vez, ele é colocado à margem da própria 
história. A voz ouvida é, não raro, a voz da instituição. Miguel Baldez (2008) enfatiza a "necessidade da participação do sujeito no desenrolar de seu processo, pois este não pode ficar estático à norma jurídica e sim, servir de instrumento de libertação do oprimido”. Observa-se que o sujeito ocupa um lugar de total desqualificação e invisibilidade. Sua história e sua verdade são interpretadas de acordo com a visão e o entendimento institucional. Exames e laudos são elaborados à sua revelia. Seria o momento de se indagar: como - mantido 'em tutela' e afastado de toda e qualquer possibilidade de decisão a respeito de si mesmo -, o sujeito poderia se constituir como tal, através de sua própria ação, se lhe negam o direito ao saber?

O descaso ao paciente encarcerado em instituições totais se reflete também nas dependências físicas do MJ. Uma passagem de Meu nome não é Johnny é esclarecedora:

\begin{abstract}
O recém-chegado tentou relaxar para dormir, mas o aspecto do ambiente não ajudava. Paredes encardidas, umidade, colchões nus, alguns focos de mofo. [...] Deitou e fechou os olhos, imaginando-se num lugar melhor, para ver se o sono perdia a cerimônia. Pouco tempo depois de ter finalmente adormecido, sentiu algo arranhando levemente sua face, como se alguém de unhas compridas estivesse tentando acordá-lo. Abriu os olhos no exato momento em que uma gorda ratazana escalava seu rosto. Ainda teve tempo de sentir o peso e o calor do bicho contra sua pele, antes de dar-lhe um violento tapa, acompanhado de um grito de horror e ódio (FIÚZA, 2004, p. 163).
\end{abstract}

Quanto à sua rotina, a instituição obedece a um regime prisional com horários pré-estabelecidos para as refeições, banhos de sol $^{8}$, e pelo 'confere’, ocasião em que os agentes de segurança verificam e confirmam o total de pacientes na casa corroborando, assim, com o seu caráter de instituição total.

Com relação às atividades terapêuticas, muito pouco é oferecido. A grande maioria dos pacientes passa a maior parte do tempo de forma ociosa, deitados pelo chão ou perambulando pelos pátios. Por algumas vezes sugerimos algum tipo de diversão e de interação entre os pacientes. Todavia estas sugestões eram, geralmente, vistas como transgressoras ou perigosas. Certa feita foi proposta à direção do hospital para que os pacientes (masculinos e femininos) pudessem sair para um passeio. A ideia seria fretar um ônibus que transportasse cerca de trinta

\footnotetext{
${ }^{8}$ Entende-se por 'banho de sol', o tempo em que o paciente permanece em espaço aberto, no convívio com os demais internados.
} 
pacientes - previamente selecionados pelas equipes técnicas -, com o intuito de levá-los à Quinta da Boa Vista. Criou-se um verdadeiro tumulto dentro da instituição, tumulto este manifestado pelos agentes de segurança como também, surpreendentemente, pela maioria dos profissionais 'psi', que consideraram a ideia 'perigosa e sem propósito'. O mesmo ocorreu quando sugerimos que os aniversários dos pacientes fossem festejados. A proposta era de que se pudessem organizar, junto com eles, comemorações a cada trimestre. Novo tumulto em solo institucional. Deste modo é possível observar que, a cada proposta de inovação ou de transformação ao já estabelecido, surge uma atitude defensiva por parte da instituição, obstaculizando qualquer tentativa de mudança. Quanto a estas questões, iremos problematizá-las com maior ênfase e detalhe no Capítulo 4, ao refletirmos sobre o saber 'psi' e suas formas possíveis de resistência.

\section{2}

Quem são essas pessoas?

A palavra que me parece mais pérfida não é a palavra 'louco', mas a que mais temo é 'doença mental'. A passagem do louco ao doente, que é aparentemente uma nova qualificação, é na verdade uma tomada de poder. E é isso que me interessou problematizar. ${ }^{9}$

Michel Foucault

\subsection{1}

Da concepção trágica à concepção crítica da loucura: do louco ao doente mental

Como se sabe, nem sempre a loucura foi encarcerada. No início do século XV o louco - então denominado lunático, pecador - usufruía de relativa liberdade e era apoiado pela caridade alheia. Em algumas localidades da Europa era comum deixar-se que o louco vagasse pelos campos, enquanto que em outras sociedades europeias ele convivia livremente junto aos mendigos, mágicos, libertinos, enfim, àqueles considerados como diferentes dos demais. Fato é que a loucura, com suas características muitas vezes extravagantes, era considerada expressão da vontade

\footnotetext{
${ }^{9}$ Foucault, par lui-même (Calderon, 2003).
} 
divina. Via-se o louco como detentor de uma sabedoria, aquele que em seu delírio proferia a verdade, aquele glorificado tanto por seu saber hermético quanto por sua ingênua franqueza. Deve-se ressaltar, contudo, que essa prática em lidar com a loucura variava de local para local, podendo encontrar-se cidades que recolhiam seus loucos em dormitórios ou ainda outras que os escorraçavam a pedradas. Enfim, como leciona Michel Foucault (2009 a), cada sociedade produzia a sua forma mesma de organização para lidar com a loucura. Algumas entendiam que como se tratava de população que não trabalhava -, esses indivíduos eram considerados marginais e improdutivos e, assim, não lhes deveria ser permitido compartilhar o espaço social. As cidades começam, então, a expulsá-los.

Nesta lógica da exclusão Foucault traz a imagem ficcional da Nau dos loucos ${ }^{10}$ que, no entanto, teve uma existência concreta nas sociedades europeias entre o século XIV e XVI. Na embarcação, o louco fica a mercê da sua própria errância; melhor dizendo, preso em sua própria liberdade. Louco e desterritorializado ele vagueia pelos mares até ser definitivamente excluído de todo e qualquer contato com o mundo.

Confiar o louco aos marinheiros é com certeza evitar que ele ficasse vagando indefinidamente entre os muros da cidade, é ter a certeza de que ele irá para longe, é torná-lo prisioneiro de sua própria partida. [...] Fechado no navio, de onde não se escapa, o louco é entregue ao rio de mil braços, ao mar de mil caminhos, a essa grande incerteza exterior a tudo. É um prisioneiro no meio da mais livre, da mais aberta das estradas: solidamente acorrentado à infinita encruzilhada. É o Passageiro por excelência, isto é, o prisioneiro da passagem. E a terra à qual aportará não é conhecida, assim como não se sabe, quando desembarca, de que terra que vem. Sua única verdade e sua única pátria são essa extensão estéril entre duas terras que não lhe podem pertencer (FOUCAULT, 2009 a, p. 11-12). ${ }^{11}$

Ironicamente - apesar da voz do louco anunciar a morte e o caos e, com isso ser afastado do convívio dos demais cidadãos -, a loucura não era algo se

\footnotetext{
10 "Um objeto novo acaba de fazer seu aparecimento na paisagem imaginária da renascença; e nela, logo ocupará lugar privilegiado: é a Nau dos loucos, estranho barco que desliza ao longo dos calmos rios da Renânia e dos canais flamengo. A Narrenschiff é, evidentemente, uma composição literária [...] mas de todas essas naves romanescas ou satíricas, a Narrenschiff é a única que teve existência real, pois eles existiram, esses barcos que levavam sua carga insana de uma cidade para outra. Os loucos tinham então uma existência facilmente errante” (Foucault, 2009, p. 9).

${ }^{11}$ No Brasil, em fins do século XIX, observa-se uma reedição, em aparência mais moderna, da Nau dos loucos das sociedades europeias: muitos estados brasileiros que não possuíam hospital psiquiátrico ou asilo costumavam enviar seus insanos para a capital federal ou para outros estados de trem, apelidado de 'trem de doido', reproduzindo, deste modo, o antigo modelo de exclusão do século XVI (Mattos, 1999).
} 
prendesse, e sim algo que circulava (Fonseca, 2002). Ao expulsá-lo para longe de seus domínios, impediam-no de circular pelas ruas, tornando-se, deste modo, um estorvo para a população. Embarcado, navegante de grandes mares e rios, era-lhe impossível escapar, pois "prisioneiro no meio da mais livre, da mais aberta das estradas: solidamente acorrentado à infinita encruzilhada” (Foucault, 2009 a, p. 12). O louco não se encontra, ainda, enclausurado: ele é aquele sujeito que fala sobre algo que o não-louco se surpreende, se inquieta, não entende, mas, ao mesmo tempo, fascinado, quer se aproximar e ouvir: trata-se da concepção trágica da loucura, quando esta ainda é tolerada por não apresentar nenhuma ameaça aparente.

Contudo, o louco, segundo a lógica de Descartes em sua obra Meditações Metafísicas, escrita e publicada pela primeira vez em 1641, é aquele que não pode pensar, ou se pensar, não pode ser louco, sugerindo com isso que, enquanto o homem sadio questiona a si mesmo, o louco não o faz. O que significa afirmar, parafraseando Machado, que “a loucura é condição de impossibilidade do pensamento; o pensamento exclui a possibilidade da loucura” (Machado, 1981, p. 61). A ‘equação cartesiana’ parece anunciar que aquele que for considerado louco não é um sujeito: tratar-se-ia, portanto, de uma 'não-pessoa'. A loucura passa a representar o negativo da razão ou o não-ser da razão; e o louco passa a ser tido como desarrazoado, um animal sem razão que deve, por esse motivo, ser asilado.

Com isso, já não basta mais afastar o louco ou deixá-lo errante, à sua própria sorte. As viagens a céu aberto nas estranhas e loucas barcaças vão dando lugar, pouco mais de um século depois, a sólidos locais fincados em terra firme: já não existe mais a nau; em seu lugar, aporta o hospital. Assim, “a loucura, cujas vozes a Renascença acaba de libertar, cuja violência, porém ela já dominou, vai ser reduzida ao silêncio pela era clássica [...].” (Foucault, 2009 a, p. 45). Destarte, aqueles passageiros anônimos são despejados pelas naus e, com o tempo, algumas cidades surgem como lugares de peregrinação. Cria-se, então, uma nova forma de assistência no que diz respeito à questão da loucura: o encarceramento dos insanos. O século XVII faz acontecer o 'grande confinamento’. Aí já não mais se ouve a voz do louco, mas tão somente o seu silêncio.

$\mathrm{Na}$ época clássica, as instituições que os recebiam não dependiam de conhecimento ou de critérios médicos para interná-los, mas tão somente, como 
nos ensina Michel Foucault (2009 a), de uma percepção social produzida por tantas outras instituições, tais como a Igreja, a polícia ou a própria família ${ }^{12}$. Estas se valiam de critérios, não da medicina, mas daqueles que diziam respeito à transgressão da razão e da moralidade para designar e excluir o louco. Dito de outra maneira, “esta percepção de desrazão não é uma percepção médica, mas ética” (Machado, 1981, p. 66), merecendo - por esta maneira que a psiquiatria tentou transformar a 'percepção social' em 'percepção médica' -, a alusão às suas 'baixas' origens. À percepção social do louco como o estranho passa-se à análise médica do desarrazoado, convertendo-se a exclusão em enclausuramento, apenas e tão somente com o intuito de preservar a ordem social, com o objetivo de defender a sociedade.

Esta, então, passa a demandar uma assepsia que acarretou no afastamento de uma massa que não se encaixava nos parâmetros sociais. Assim, o louco e os outros marginalizados pela consciência hegemônica - os hereges, libertinos, homossexuais, filhos ingratos, e toda uma sorte de indivíduos colocados à margem -, são capturados agora, em instituições fechadas.

Cria-se, então em Paris, em 1656, o Hospital Geral que, antes de ser um estabelecimento médico, trata-se de uma estrutura semijurídica, entregue a diretores nomeados vitaliciamente com plenos poderes para decidir, julgar e executar sobre a vida daqueles lá internados.

É sabido que o século XVII criou vastas casas de internamento; não é muito sabido que mais de um habitante em cada cem da cidade de Paris viu-se fechado numa delas, por alguns meses. A partir de Pinel, Tuke, Wagnitz, sabe-se que os loucos, durante um século e meio, foram postos sob o regime desse internamento [...]. Mas nunca aconteceu de seu estatuto nelas ser claramente determinado, em qual sentido tinha essa vizinhança que parecia atribuir uma mesma pátria aos pobres, aos desempregados, aos correcionários e aos insanos. É entre os muros do internamento que Pinel e a psiquiatria do século XIX encontrarão os loucos; é lá - não nos esqueçamos - que eles o deixarão, não sem antes se vangloriarem por terem-nos 'libertado'. A partir da metade do século XVII, a loucura esteve ligada a essa terra de internamentos, e ao gesto que lhe designava essa terra como seu local natural (FOUCAULT, 2009 a, p.48. Grifo nosso).

\footnotetext{
${ }^{12}$ Era comum, no século XVIII, que amigos, parentes ou mesmo vizinhos solicitassem à autoridade real a reclusão ou o afastamento de um elemento perturbador, através das lettres de cachet, instrumentos que datam entre 1660 a 1760 e ocupam lugar de destaque no que diz respeito à análise foucaultiana das relações entre o poder e o discurso. Tratava-se de documentos emitidos em nome do rei de França - não necessariamente por sua própria iniciativa -, que tinham como função manter em regime de prisão ou de internamento todo o indivíduo cujo comportamento era, no discurso desses mesmos documentos, tipificados de 'indesejáveis'.
} 
Assim, o grande confinamento acontece: internam-se, indiscriminadamente, não só o louco, mas todos aqueles que se diferenciavam das normas vigentes ou, como sustenta Foucault (1968), aqueles que apresentassem qualquer tipo de 'alteração'. É a chamada época do 'Grande Enclausuramento', constituindo-se a primeira tentativa de se alocar os indesejáveis sociais em um espaço fechado e isolado. Estas figuras da desrazão - os insanos, as prostitutas, os vagabundos e todos aqueles que infringiam a ordem da família e da igreja - são vistas pela sociedade como o 'outro negativo' e, portanto, devem ser banidos e isolados do meio, tal qual o modelo da peste o fez no início do século XVIII.

Foucault (2001) refere-se ao modelo da peste como tendo sido historicamente ativado na época do 'grande internamento'. Este modelo, quase tão antigo quanto o modelo de exclusão do leproso em meados do século XVII, preocupa-se, agora, em uma análise sutil e detalhada do espaço ocupado. Faz-se, portanto mister distribuir, dividir, inspecionar e, por fim, vigiar os indivíduos. Alguma semelhança com o modelo da internação? Certamente, toda a semelhança! Enquanto que no modelo da lepra a rejeição desses indivíduos se dá num mundo exterior, fora dos limites da cidade - através de práticas de marginalização -, o modelo pestífero é, ao contrário, um modelo de inclusão, onde "não se trata de expulsar, mas de estabelecer, de fixar, de atribuir um lugar, de definir presenças, e presenças controladas. Não rejeição, mas inclusão” (Foucault, 2001, p. 57). A substituição da peste pela lepra corresponde, de acordo com o autor, ao processo de invenção das tecnologias de poder que produzem efeitos. Sobre isso falaremos mais adiante, na terceira parte do Capítulo 3.

Contudo, ao final do século XVIII, a sociedade clamava por um local específico e seguro que a garantisse contra os perigos da loucura. Onde alocar o louco: nas casas de correção inseridas numa estrutura carcerária, nas instituições hospitalares, ou devolvendo-os às suas famílias? Era preciso encontrar um meio termo entre o dever da assistência - revelado por atitudes de piedade - e os temores que fomentavam o pavor e a repugnância em torno da figura do alienado (Foucault, 1968). Fato é que ao louco foi proposta uma assistência intramuros, assegurando-se, deste modo, a quietude daqueles que habitavam o espaço extramuros. O internamento passa a ganhar novos contornos: determina-se aos 
insanos a exclusão com cuidados médicos, o que significava que, apesar de encarcerados, ser-lhes-ia dado o benefício de tratamento. Agora,

o internamento recebeu sua carta de nobreza médica, tornou-se lugar de cura, não mais o lugar onde a loucura espreitava e se conservava obscuramente até a morte, mas o lugar onde, por uma espécie de mecanismo autóctone, se supõe que ela acabe por suprimir a si mesma. [...] Com o espaço do internamento assim habitado por valores novos e por todo um movimento que lhe era desconhecido, a medicina poderá, e só agora, apossar-se do asilo e chamar para si todas as experiências da loucura (FOUCAULT, 2009 a, p. 433-434).

Em momento oportuno, iremos nos remeter ao método de estudo arqueogenealógico de Michel Foucault, que procura problematizar como e por que se dão essas rupturas e descontinuidades da história que, segundo o autor, são produzidas por diferentes formas de saber/poder que permeiam o campo das relações.

Mas voltemos ao internamento, invenção própria do século XVIII, que usurpa da loucura a sua liberdade ilusória, viajante, e a enjaula à razão e às regras da moral. Agora o louco é extraído daqueles outros, pobres e devassos, e passa a ser confinado não mais no hospital geral. O louco passa a ser asilado, não mais como desarrazoado - à visão trágica da loucura -, mas sim, como alienado, inserido numa nova perspectiva: a da visão crítica da loucura. Assim, inventa-se o asilo. Assim, nasce um corpo de conhecimento e de especialidade: assim, nasce a psiquiatria, saudada como a ciência que desvenda a verdade da loucura, ou seja, a loucura como doença mental. O louco, agora transformado em doente mental, torna-se o seu objeto, e o asilo o espaço institucional de sua intervenção.

Não obstante, essas novas casas de internação não tinham como objetivo tratar o sujeito, mas tão somente excluí-lo da sociedade. Gradativamente vão se tornando locais restritos aos loucos que, por sua vez, serão mantidos sob o manto da exclusão.

[...] a doença mental é um conceito relativamente recente; seu aparecimento decorre de uma complexa determinação histórica e é fruto de uma mudança da sensibilidade de toda uma época. Mais ainda, a interpretação da loucura como doença tem como correlato a inauguração de um aparato institucional para tratamento dessa novidade nosológica [...] (GABBAY e VILHENA, 2010, p. 42).

Em História da Loucura, Foucault (2009 a) demonstra que, tanto a doença mental como a intervenção da medicina com relação ao louco é historicamente 
datada: não é senão no final do século XIX que se dá início ao processo de patologização da loucura e é, neste momento, que o louco, não mais um desarrazoado, mas, agora, um alienado será, então, incurso na lei de $1838^{13}$ “que o fixará, por mais de um século, num completo estado de minoridade social” (Castel, 1978, p. 55). Com isto permitiu-se à medicina mental se ocupar da recuperação e da cura do alienado, ou seja, “ao postularem a minoridade do louco e o seu isolamento como medida terapêutica necessária ao controle de sua periculosidade, os alienistas ofereceram uma justificativa médica à sua repressão” (Arantes, 2011, p. 19). A partir daí, construiu-se discursos - legitimados ou não sobre a doença mental, e a psiquiatria, ao invés de ter sido quem descobriu a essência da loucura e a libertou, passa a ser a radicalização de um processo de dominação do louco (Foucault, 2009 b). Dito de outra maneira, produziu-se a transformação da experiência da loucura em doença mental, isto é, em objeto de discurso com ares de cientificidade, visando fundar formas de intervenção sobre o agora denominado doente mental. Quanto a essas práticas discursivas que produzem verdades, iremos discuti-las nos próximos capítulos desse trabalho.

Indagaríamos de que maneira então reconhecer a loucura, a não ser através de um saber e de um conhecimento discursivo que a interroga no lugar mesmo onde ela habita - o asilo? De que maneira se faz esse reconhecimento que não admite contestação possível?

Ainda em sua vasta e complexa História da Loucura, Michel Foucault analisa que não é a partir dos loucos que o pensamento clássico interroga sobre a loucura, mas, ao contrário, ele o faz a partir da doença em si, deduzindo-a, inferindo-a num campo de racionalidade sem, contudo, deixar que o louco fale de si mesmo. É necessário interrogar-se e inventariar-se tudo o que há de mais manifesto, de mais evidente naquilo que se apresenta como sintomático. É diligenciar, procurar e encontrar o que há de verdade na doença, reconstituindo-a “com a exatidão de um retrato” (Foucault, 2009 a, p. 190). Deste modo, abre-se o espaço da classificação da loucura colocando-a, através de um aprisionamento moral, em seu devido lugar: o asilo de loucos.

\footnotetext{
${ }^{13}$ A Lei de 30 de Junho de 1838, elaborada por Esquirol e Pinel, foi modelo para muitos países. Ela tinha como objetivo a obrigatoriedade de cuidado aos insanos através da criação de estabelecimentos públicos, então denominados asilos.
} 
Como vimos anteriormente, esta visão asilar da loucura - ironicamente chamada de libertação dos alienados -, deu-se a partir da lendária atitude de Pinel ao desacorrentar os loucos. Contudo, esta 'libertação da loucura' decantada por Pinel, não permitiu conceder aos alienados uma atenção médica nem sequer filantrópica; muito pelo contrário, jamais se uniu, de forma tão rija e solidamente a loucura ao internamento.

O asilo construído pelo escrúpulo de Pinel não serviu para nada e não protegeu o mundo contemporâneo contra a grande maré da loucura. Ou melhor, serviu, serviu muito bem. Se libertou o louco da desumanidade de suas correntes, acorrentou ao louco o homem e sua verdade. Com isso, o homem tem acesso a si mesmo como ser verdadeiro, mas esse ser verdadeiro só lhe é dado na forma da alienação. (Foucault, 2009 a, p. 522)

Nesta sua obra, Foucault desmistifica o humanismo terapêutico e libertador de Pinel, desmascarando a psiquiatria como sendo a responsável pelo tratamento da loucura. Em um caminho contrário, ele "mostra o caminho que foi preciso a história seguir para que a psiquiatria tornasse o louco doente mental” (Machado, 1981, p. 58).

$\mathrm{O}$ ato fundador de Pinel não é retirar as correntes dos alienados, mas sim o ordenamento do espaço hospitalar. Através da "exclusão", do "isolamento", do "afastamento" para prédios distintos [...] a categoria da loucura se destaca, então, em sua especificidade [...]. E, dessa maneira, ela se tornou doença. A partir do momento em que é isolado em seu próprio espaço, o insano aparece, sem duvida, sequestrado como os outros, porém, por outras razões. Por causa de doença (CASTEL, 1978, p. 83).

Deste modo, segundo Michel Foucault, perde-se, definitivamente, a relação com a loucura e mantém-se uma ligação lastimável com a doença mental, lá, onde se imagina o perigo, a revelação, a verdade; lá, onde surge “o temor, incessantemente repetido durante séculos, de ver a estiagem da loucura elevar-se e submergir o mundo” (Foucault, 1964, p. 213). Ao migrar para a região da doença mental, a loucura

é incluída no universo dos interditos de linguagem; a internação clássica enreda com a loucura [...] tudo o que caracteriza o mundo falado e interditado da desrazão; a loucura é a linguagem excluída - aquela que, contra o código da língua, pronuncia palavras sem significação ('os insensatos', 'os imbecis', 'os dementes'), ou a linguagem que pronuncia palavras sacralizadas ('os violentos', 'os furiosos'), ou ainda a que faz passar significações interditadas ('os libertinos', 
'os obstinados'). A reforma de Pinel é muito mais um arremate visível dessa repressão da loucura como palavra do que uma modificação (FOUCAULT, 1964, p. 215).

De acordo com o autor, o sujeito-louco só pôde ser novamente ouvido, de fato, a partir da contribuição da obra de Sigmund Freud, quando, então, dá-se a palavra ao louco e ouve-se seu delírio, aparentemente sem sentido.

Asilando-se os excluídos, tem-se a possibilidade de estudá-los em seus pormenores e, deste modo não somente extrair-lhes a sua verdade, mas igualmente categorizá-los e rotulá-los. Como já dissemos, transmuta-se a representação do louco para o de doente mental. Para tanto, criam-se domínios de conhecimento e uma série de disciplinas - tais como a psiquiatria e a psicologia que passam a discorrer sobre a doença através de discursos com estatuto de verdade observável e ordenável por seus especialistas. Com relação a esse tópico iremos mais à frente discuti-lo.

Com a presença regular e contínua da figura do médico nos locais de internação, constata-se a sua função moral e de caráter higienista, mais do que de caráter curativo propriamente dito: o médico é "o agente das sínteses morais” (Foucault, 1968, p. 82). Por sua vez, o asilo mesmo é marcado não somente por suas características de tratamento moral, mas também se constitui como uma estrutura que objetiva a loucura como doença mental (Fonseca, 2002).

\section{2 .2}

\section{Surge uma nova invenção: o 'crime de loucura'}

Faz parte integral da psiquiatria, enquanto 'ciência' da mente humana, a noção de que os esquizofrênicos paranoides são perigosos. Assim como os verdadeiros crentes do judaísmo acreditam que os judeus são o Povo Escolhido e assim como os verdadeiros crentes do cristianismo acreditam que Jesus é Deus, assim também os verdadeiros crentes da psiquiatria acreditam que a esquizofrenia paranoide é uma doença identificável e que os que sofrem dessa doença são perigosos. ${ }^{14}$

Thomas Szasz

\footnotetext{
${ }^{14}$ A Escravidão Psiquiátrica (1986).
} 
Enganam-se aqueles que creem terem as ciências 'psi' parado por aí. Além de observar-se que o hospício fabrica a loucura - pois que ele introduz no jogo do médico e do paciente, a loucura como anomalia, como perigo, como objeto de investigação científica -, constata-se também a criação de novas figuras e novas terminologias no campo dessas ciências. (Fonseca, 2002).

Michel Foucault inicia a sua aula de cinco de fevereiro de 1975, no Collège de France, apontando para um novo personagem - o do 'monstro' - que passa a circunscrever os anos iniciais da psiquiatria penal e a sua transição para a figura do anormal e do mais tarde denominado 'louco-criminoso'. A partir de uma série de $\operatorname{casos}^{15}$ que apresentavam aproximadamente a mesma forma e que se desenrolaram no final do século XIX - entre 1800 e 1835 -, a psiquiatria criminal se viu prestes a descobrir que certos atos monstruosos nos quais não se podia observar nenhum interesse aparente, eram produzidos, não pela ausência da razão, mas por uma certa dinâmica mórbida dos instintos, por “movimentos inesperados e incontroláveis das paixões e afetos” (Carrara, 1998, p. 72).

Constituía-se, desse modo, a categoria nosológica da 'monomania'16 que, segundo Robert Castel, foi tomada pela medicina mental para justificar e interpretar um novo tipo de comportamento que lhe escapava e que, por suposto, deveria ser atribuída ao campo do judiciário (Castel, 1977). Desde aí, a noção de instinto, segundo Foucault, terá um papel central no problema da anomalia: ele vai tornar inteligível ao mecanismo penal, um crime sem interesse e, destarte, não passível de ser punido. Assim, partindo-se desses casos, inauguraram-se as reflexões iniciais sobre a relação entre crime e loucura. Ao problematizá-los, Foucault passa a questionar o motivo pelo qual estes crimes tomaram tanta importância nos meios médicos e jurídicos da época. O assassinato monstruoso e sem motivo configura-se, agora, como 'loucura criminal', loucura esta que só teria por sintoma o próprio crime. Szasz é enfático em sua crítica quanto à tentativa de se relacionar crime e loucura:

\footnotetext{
${ }^{15} \mathrm{O}$ autor aponta para os três grandes monstros fundadores da psiquiatria criminal: a mulher de Sélestat, que matou a própria filha, cortou-lhe em pedaços e comeu-a; o caso de Papavoine que assassinou duas crianças e, finalmente, a Sra. Cornier que matou uma menina de dezoito meses, cortando-lhe o pescoço e separando-lhe o tronco da cabeça.

${ }^{16}$ Segundo Carrara (1998), a monomania foi entendida, inicialmente, como uma forma de loucura definida pela presença de delírios. Progressivamente passou a codificar uma perturbação mental acompanhada de emoções incontroláveis.
} 
A mistificação do conceito de doença mental e sua mistura com o crime são agora úteis para a psiquiatria institucional, assim como a mistificação do conceito de bruxaria e sua mistura com o de envenenamento já foi útil para a Inquisição. [...] A doença mental é o conceito nuclear da psiquiatria institucional, assim como o era a heresia para a teologia da Inquisição. $\mathrm{O}$ fato tanto da heresia quanto a doença mental serem crimes de pensamento - e não crimes de ato -, ajuda a explicar os métodos asquerosos usados em sua averiguação (SZASZ, 1978, p. 51).

Tal figura do anormal, uma espécie de descendente do monstro humano que tanto apavorou o século XVIII, foi recoberta pela categoria da 'degenerescência ${ }^{17}$ ' que, por sua vez, irá servir de justificativa para o uso de todas as futuras técnicas de classificação e de intervenção sobre esta nova classe psiquiátrica. A partir da noção de degeneração e das análises da hereditariedade, a psiquiatria deu lugar a uma espécie de racismo, qual seja, o racismo contra o anormal, contra aqueles indivíduos que, portadores de um estigma ou de um defeito qualquer, pudessem transmitir por herança, o mal que carregavam em si. A mais, a organização de uma rede institucional complexa cumprirá com o propósito não somente de acolhimento desses anormais, mas principalmente como instrumento de defesa da sociedade, funcionando como 'caça aos degenerados', àquele que é portador de perigo, o inacessível à pena, o incurável (Foucault, 2001).

Impôs-se, assim, a intervenção da psiquiatria no campo jurídico.

Em riquíssimo texto de $1978^{18}$, Michel Foucault questiona por que a ciência psiquiátrica se obstinou tanto em reivindicar como loucos aqueles que, até então, eram considerados simples criminosos? Por que psiquiatras tentaram tomar parte dos mecanismos penais e procuraram se adonar do direito de intervenção, sustentando que existiam atos de loucura que apenas se manifestavam nos crimes hediondos e em mais nenhuma outra circunstância? Qual era o interesse da medicina em se aliar às práticas jurídicas? Por que do esforço em tentar patologizar o crime?

\footnotetext{
${ }^{17} \mathrm{O}$ termo 'degenerescência' é formulado por Morel em 1857 no seu Traité des Dégénérescences. Segundo o autor, a degeneração, correlativa do pecado original, consistiria na transmissão à descendência dos traços mórbidos adquiridos pelos antecessores e, na medida em que eram transmitidos através das gerações, seus efeitos tenderiam a se acentuar, levando à completa desfiguração daquela linhagem. Em decorrência dessa teoria, muitos projetos de intervenção social de cunho higienista foram desenvolvidos, a fim de impedir a propagação da degeneração da raça.

${ }^{18}$ A evolução da noção de "indivíduo perigoso" na psiquiatria legal do século XIX (1978).
} 
Segundo o autor, é nesse contexto que a psiquiatria inventa a chamada 'monomania homicida'19, conceito acatado imediatamente pelas instâncias jurídicas que, por sua vez, precisavam saber por que punir: encontra-se aí encravada a noção de periculosidade e, consequentemente, o ponto de partida para a concepção do conceito de 'indivíduo perigoso'. O crime se tornou para a psiquiatria “uma modalidade de poder a garantir e a justificar” (Foucault, 1978 a, p. 9). Observa-se, desse modo, que ela passa a conquistar um grande prestígio na virada entre os séculos XVIII e XIX pelo fato de funcionar como reação aos perigos do corpo social. A psiquiatria funcionou não como uma especialização do saber ou da teoria médica, mas antes como um ramo especializado da higiene pública, institucionalizando-se como domínio particular da proteção social (Foucault, 2001). Era preciso defender a sociedade dos ‘indivíduos perigosos’. E, assim, finalmente inscrita na lei de 1838, ela se vê consagrada como uma disciplina médica e de higiene pública.

\begin{abstract}
Se o crime se tornou uma aposta importante para os psiquiatras é porque se tratava menos de um campo a conquistar do que uma modalidade de poder a garantir e a justificar. Se a psiquiatria se tornou tão importante no século XVIII não foi simplesmente porque ela aplicava uma nova racionalidade médica às desordens da mente ou da conduta, foi também porque ela funcionava como uma forma de higiene pública (grifo nosso). [...] A psiquiatria, na virada entre os séculos XVIII e XIX, conseguiu sua autonomia e se revestiu de tanto prestígio pelo fato de ter podido se inscrever no âmbito de uma medicina concebida como reação aos perigos inerentes ao corpo social. [...] A psiquiatria do século XIX, pelo menos tanto quanto uma medicina da alma individual foi uma medicina do corpo coletivo (FOUCAULT, 1978 a, p. 9-10).
\end{abstract}

Ora, vê-se, deste modo, a importância que era para a psiquiatria demonstrar a existência de tão visionário quadro de loucura, especialmente sob dois aspectos: para mostrar, primeiramente, que em sua forma mais extrema, a loucura nada mais é do que crime, ou seja, a loucura é, no limite, sempre perigosa. Em segundo lugar, mas não menos importante, assegurar que ninguém pode prever a loucura, mas tão somente um médico especialista: “aquele que tem um olhar adestrado, uma longa experiência, um saber bem armado” (Foucault, 1978 a, p. 10). Constitui-se, assim, de um lado, a figura do perito psiquiátrico - a quem reservamos a segunda parte do Capítulo 2 desse trabalho -, e do outro, o sujeito

\footnotetext{
${ }^{19}$ A descoberta de Esquirol, alcunhada de 'monomania homicida' acreditava mostrar que um certo tipo de crime atestava a loucura por si só, exclusivamente por sua presença (Castel, 1977).
} 
perigoso. E é este sujeito de atos incontroláveis que emergirá como o irresponsável, aquele que a justiça se desobrigará de punir, incumbindo-o à prisão psiquiátrica. O Código Penal de 1890 em seu titulo III, art. 29, decreta que:

Os individuos isentos de culpabilidade em resultado de affecção mental serão entregues a suas familias, ou recolhidos a hospitaes de alineados, si o seu estado mental assim exigir para segurança do publico (Código Penal Brasileiro, 1890).

Portanto, a esta época, o crime é qualificado dependendo da culpabilidade ou não do autor: os loucos são, então, considerados 'não culpados'. Neste momento, são produzidas novas formas de objetivação daquele já designado monstruoso, perigoso, louco-criminoso e, agora, paciente 'inimputável' reservando-lhe o manicômio judiciário como local de segregação. Sem dúvida, ao surgir a figura do alienista para proteger simultaneamente o louco e a sociedade, os manicômios tornam-se o refúgio para uma comunidade que não tolera a loucura (Rauter, 2003). Esta nova categoria nosográfica, relacionando crime e loucura, foi fomentada com o surgimento da criminologia, que tentou explicar o comportamento criminoso, baseando-se nas noções de hereditariedade e de degeneração. Assim como no século XIX, a criminologia, como “a mais pragmática e utilitária entre as ciências humanas [...], segue sendo um poderoso instrumento de controle social” (Rauter, 2003). Vamos a ela.

\section{3}

\section{Quem gerencia tudo isso?}

\subsection{1}

\section{O casamento do Direito com a Psiquiatria: gera-se o inimputável}

O complexo e crítico Os Anormais, de Michel Foucault, consiste na transcrição das onze aulas do curso ministrado por ele no Collège de France em 1975. É exatamente na segunda aula que o autor trata da relação tensa e ambígua entre a Psiquiatria e o Direito no que diz respeito ao julgamento da sanidade mental no campo criminal.

Cumpre lembrar, acompanhando Foucault, que "foram os psiquiatras que, por volta de 1830, se impuseram de modo absoluto à prática penal” (Foucault, 
1974, p. 297). Àquela época, a justiça não dispunha de meios para explicar determinados crimes, cujas características afiguravam-se incompreensíveis e a psiquiatria, por sua vez, tentou tomar para si um papel judicial no interior mesmo do campo jurídico. Destarte, o alienista, a partir do século XIX, passa a ter um papel cada vez mais preponderante no tribunal, constituindo-se, com isso, uma progressiva tendência à indiferenciação entre os papéis do médico e do juiz.

Trata-se, agora, como bem argumenta Brito e Souto (2007), não de averiguação de crime praticado pelo sujeito acometido de doença, mas, ao contrário, de investigação da existência de doença mental em virtude do cometimento do delito. Ainda, segundo a autora, a Psiquiatria surge como instrumento de transformação do louco em doente mental e, a sua história se confunde com a história mesma do Direito Penal. A medicina psiquiátrica passa a intervir na modulação da pena e com isso, cada vez menos, os conceitos por ela utilizados tornam-se de caráter médico: surge a figura, cunhada por Foucault, do médico-juiz, , aquele que pretende tratar, julgando. Conforme leciona o autor, a psiquiatria para se justificar como poder e ciência da higiene pública - e, portanto, de proteção social -, precisa mostrar que é capaz de perceber um certo perigo, mesmo onde nenhum outro possa ver (Foucault, 2001).

Assim, no decorrer do século XX, organiza-se efetivamente um poder médico-judiciário que leva o indivíduo diante de um tribunal não apenas com o seu crime: ele vai acompanhado de um exame psiquiátrico, o qual que diz muito mais respeito ao tipo de vida que este sujeito está submetido, ao seu comportamento disciplinar, à sua relação com seus subordinados dentro do cárcere, enfim, ao nível de perigo que ele ainda possa representar, do que, na realidade, ao próprio ato por ele cometido. Segundo Cristina Rauter, passa-se a exercer um tipo de controle mais amplo e eficiente:

Enquanto a justiça só pode agir sobre o delito quando este já tiver sido cometido, a psiquiatria aparece como capaz de prevê-lo em função de critérios de periculosidade definidos 'cientificamente'. $\mathrm{O}$ ato criminoso torna-se resultado inevitável de uma condição mórbida que já se esboçava desde a infância. A criminalidade atravessa a vida do indivíduo, o crime é sempre uma virtualidade (RAUTER, 2003, p. 113).

Vê-se, destarte, a produção de um discurso criminológico sobre a figura do louco-criminoso que, desconhecida pelos juristas, passam estes a contar com a 
intervenção da psiquiatria para assessorá-los, resultando, assim, na profícua união entre o direito e a medicina que, agora, funcionam juntos como a principal defesa à sociedade contra essa figura estranha e obscura do louco-criminoso.

Conforme pensamos, a noção de medida de segurança perde a sua especificidade como medida de tratamento e ganha contornos puramente jurídicos. Nota-se, neste caso, que a psiquiatria - e por que não dizer também a psicologia -, funciona como uma prática essencialmente disciplinar, coercitiva e produtora de subjetividade: em seu nome o sujeito inimputável não só é produzido como também é condenado. Como já dissemos, é o manicômio o lugar que lhe é destinado. Detenhamo-nos um pouco sobre ele - o MJ.

O Manicômio Judiciário (MJ) ${ }^{20}$ é um hospital psiquiátrico-penal, que custodia em sistema de reclusão, sob regime fechado, indivíduos portadores de sofrimento mental que cometeram crime. Sua população é composta por cerca de 200 pacientes, sendo a grande maioria masculina. Ao longo dos anos lá trabalhados, constatamos que o MJ abriga uma série distinta de pacientes portadores de transtorno mental, que se distribuem em uma escala que varia, tanto de acordo com o tipo de delito cometido, quanto com o nível de seu comprometimento psíquico. Assim, poderíamos observar, por um lado, desde as expressões mais brandas de esquizofrenia, até as mais sérias e agudas formas de psicose, como também uma variação entre alguns tipos de delito considerados leves até aqueles classificados como mais graves. Estes indivíduos, considerados por lei como sendo inimputáveis, encontram-se incursos no Art. 26 do Código Penal $^{21}$, que afirma ser

isento de pena o agente que, por doença mental ou desenvolvimento mental incompleto ou retardado, era, ao tempo da ação ou da omissão, inteiramente incapaz de entender o caráter ilícito do fato ou de determinar-se de acordo com esse entendimento. A pena pode ser reduzida de um a dois terços, se o agente em virtude de perturbação de saúde mental ou por desenvolvimento mental incompleto ou retardado, não era inteiramente capaz de entender o caráter ilícito

\footnotetext{
${ }^{20}$ Apesar da mudança ocorrida em sua nomenclatura a partir do falecimento de Heitor Carrilho, em 1954 - passando a ser nomeado de hospital ao invés de manicômio -, optei por manter a utilização de Manicômio Judiciário, usando a sigla MJ, por acreditar que desta forma estaria sendo mais fiel à idéia mesma que ele representa. Parece-nos que de nada adiantaria mudar-se o nome se a prática continua sendo a mesma.

${ }^{21}$ O Código Penal vigente é ainda o de 1940, ao qual foram feitas algumas alterações através da Lei de Execuções Penais 7.209/84. Entretanto, ainda permanece a mesma orientação no que se refere à atuação frente ao doente mental.
} 
do fato ou de determinar-se de acordo com esse entendimento (Decreto-Lei 7209 de 11 de Julho de 1984, Código Penal Brasileiro).

Uma vez enquadrados no artigo 26 do Código Penal, os mesmos serão absolvidos de seus crimes, mas pesará sobre eles uma nova modalidade de apenação - a ‘medida de segurança' - que será, no próximo subcapítulo, problematizada.

\subsection{2}

\section{O surgimento da Criminologia e suas confusas terminologias}

O termo Criminologia foi criado por Raphael Garófalo, como sendo a ciência da criminalidade, do delito e da pena. Baseada na observação e nos fatos, a criminologia tratava de explicar a origem da delinquência. Garófalo concebeu sua concepção de delito natural partindo da ideia lombrosiana do 'criminoso nato'. Este conceito apareceu em 1871 com a publicação da obra L'Uomo delinqüente de Cesare Lombroso, que acreditava ser o criminoso possuidor de uma série de estigmas anatômicos indicadores de certas anomalias.

As ideias defendidas por Lombroso acerca do 'criminoso nato' professavam que, pela análise de determinadas características somáticas seria possível antever aqueles indivíduos que se voltariam para o crime. Lombroso médico de pensamento positivista - realizava estudos de anomalia craniana nos estabelecimentos prisionais italianos, tentando responder às questões deterministas a partir da chamada antropometria ${ }^{22}$ criminal. Para ele, o individuo criminoso tinha em sua face - e o autor acreditava que o rosto era o 'espelho da alma’ -, aquilo que dizia respeito ao próprio crime, a algo intrínseco à subjetividade e ao corpo desse sujeito, que seria, então, criminoso por essência. O delinquente era considerado um 'louco atávico' que produzia os instintos de seus ancestrais mais primitivos.

Foi por exemplo, através da comparação das medidas do corpo humano que cientistas do século XIX chegaram à conclusão de que o negro era inferior ao branco por possuir um cérebro menor do que aquele. As pessoas já não eram

\footnotetext{
${ }^{22}$ Processo ou técnica de mensuração do corpo humano ou de suas várias partes. (Novo Dicionário Aurélio)
} 
definidas apenas pela cor da pele, ou pelo ângulo facial. Começaram a surgir maneiras cada vez mais refinadas de classificação, que isolavam e estigmatizavam aqueles que não cumpriam o padrão pré-estabelecido pela sociedade de classes. A ciência passa a classificar o sujeito com fins de controle e segregação. Aqueles conotados como diferentes, ocuparam e ocupam na historia e nas relações de poder, um lugar à margem, à exclusão.

A partir daí, todas as pesquisas científicas dobrariam seus esforços para demonstrar que os comportamentos antissociais provinham essencialmente de causas orgânicas e, até mesmo o crime, deveria ser explicado por meio de fenômenos causais. Órgãos internos e externos eram avaliados com o objetivo de relacionar suas lesões às manifestações da alienação mental. A maioria dos documentos clínicos traz descrição minuciosa desses caracteres morfológicos, sendo registrados também os traços físicos indicativos de degeneração.

Em uma das conferências proferidas por Franco Basaglia, quando de sua vinda ao Brasil em 1979, o psiquiatra - como sempre muito perspicaz e espirituoso -, tece um breve comentário sobre Lombroso, atribuindo-lhe caráter “reacionário, mas que naquela época se fazia passar por socialista” (Basaglia, 1982). Lembrando que foi ele quem se encarregou em buscar as origens físicas da doença mental, associando características anatômicas a tipos de criminalidade, Basaglia nos faz remeter a outros tantos psiquiatras do início do século XIX.

Como postulava Berardinelli na década de 1930, o estudo biotipológico dos indivíduos permitia prever e, por isso, prevenir os delitos. Ele não só assim o afirma, como também o reafirma, baseando-se em outros autores da época:

Boxich e DiTullio encontraram disposição para certas especies de delictos em determinados typos morphologicos. Segundo Boxich os delinquentes não violentos são geralmente longilineos e os violentos, brevilineos. Di Tullio chegou á conclusão de que nos ladrões predomina a constituição longilinea, microsplanchnica, hypervoluida, hypovegetativa, typo cranio-facial assymetrico; nos criminosos mixtos (contra as pessoas e a propriedade), a constituição morphologica e o typo cranio-facial comuns (BERARDINELLI, 1932, p. 212).

Assim como Lombroso, outros adeptos da escola positivista de direito penal, consideravam que os criminosos estariam divididos por classes, de acordo com suas tendências hereditárias, ou de temperamento, ou ainda em função de um meio social pervertido (Carrara, 1998). Sem dúvida, podemos notar que a 
Criminologia constituiu-se em teses fortemente centradas em pressupostos racistas e preconceituosos que conduziam à conclusão de que certos indivíduos considerados criminosos eram, na verdade, uma subclasse do gênero humano. Como aponta Salo Carvalho, Lombroso, ao concluir sua investigação sobre a fisionomia dos criminosos, observa que “embora não tenham sempre aspecto assustador, demonstram certas características análogas às dos selvagens” (Carvalho, 2008, p. 278) confirmando, assim, o aspecto preconceituoso de seus estudos.

A noção lombrosiana de 'criminoso nato' - cujas marcas anatômicas eram previamente detectadas - permitiriam uma política de intervenção anterior mesmo à consecução do crime. Deste modo, os sistemas de classificação do século XVIII foram expandidos e aperfeiçoados - inclusive até a época atual -, objetivando segregar o chamado ‘indivíduo perigoso’ do restante da sociedade.

Com efeito, como leciona Fonseca (2002, p. 83), o que passa a importar agora para a psiquiatria não é se o indivíduo se encontra incapaz como sujeito jurídico, mas se o mesmo seria capaz de perturbar a ordem ou ameaçar a segurança pública. É sobre este sujeito que ela irá se debruçar como objeto de análise e de atuação, certificando o perigo que ele representa para a família e à sociedade em geral. Ora, pergunta-se: o que faz desse sujeito um indivíduo perigoso? A partir de que condições ele constitui uma ameaça social? Para a psiquiatria ele assim será considerado toda a vez que se conduzir fora das regras da ordem instituída. Segundo análise de Lopes, “urge fazer-se a profilaxia da herança patológica. E para essa profilaxia temos felizmente regras e normas de higiene da raça, de eugenia, que precisam ser acatadas” (Lopes, 1934, p.76-77. Grifo nosso). Como ilustração, passemos à seguinte descrição:

Luigi B. è un tipo di criminale medio tra il delinquente istintivo e il pazzo. Folle morale ragionante, há forti tendenze paranoidi e non è improbabile diventi, presto o tardi, um paranóico conclamato, parziale o completo. Figlio del lastrico di Torino, l'abbandono, la miseria fanno di lui um tipo di delinquente sociale e, in um'ulteriore tappa, um pazzo sociale. Non mancano però i caratteri congeniti. $\grave{E}$ nato settimestre da parenti immorali. L'ambiente e la predisposizione sono $i$ due fattori di questo prodotto misto di vagabondo, di squilibrato e di ladro. E del ladro ha anche veramente la fisionomia falsa e untuosa, le mani esili e lunghe, il camminare dinoccolato, ecc. Dal punto di vista psicopatico è um paranoide che conserva il potere lógico (MANDALARI, 1901, p. 99). ${ }^{23}$

\footnotetext{
23 "Luigi B. é um tipo criminal médio entre o delinquente instintivo e o louco. Louco moral pensante tem fortes tendências paranoicas e não é improvável que se torne, cedo ou tarde, um
} 
Os postulados da escola positivista são sentidos até os dias de hoje, através da criação de inúmeras noções no campo jurídico-psiquiátrico, e eles produziram as noções de periculosidade, medida de segurança, e tantas outras. Inicialmente iremos discutir as questões relativas à 'periculosidade' do agente para, em seguida, voltarmos a nossa atenção ao instituto da 'medida de segurança' e, finalmente, ao conceito de 'virtualidade’, este último de acordo com a concepção foucaultiana.

Como vimos anteriormente, a psiquiatria, ao longo de sua história, apresenta o louco-criminoso como um ser imprevisível, selvagem, dissociado de qualquer norma ou lei, que age unicamente à base da crueldade de seus instintos. Os seus atos parecem incompreensíveis, sem razão aparente, isentos de qualquer significação. De acordo com Michel Foucault, até o final século XVIII, o direito penal apenas situava a questão da loucura nos casos em que o Código Civil e o direito canônico também a postulavam. Ou seja, quando a loucura se apresentava na forma de debilidade mental ou demência, momento em ela se manifestava por sinais facilmente reconhecíveis. Mas, a partir do início do século XIX, em função de uma série de delitos graves ocorridos em diferentes lugares na Europa, deu-se início, efetivamente, à intervenção da psiquiatria no âmbito jurídico. A psiquiatria, segundo o autor, inventou "a entidade fictícia de um crime louco, [...] uma loucura que nada mais é do que crime” (Foucault, 1978 a). Em outras palavras, uma loucura que só se manifestaria no momento e nas formas do crime:

O individuo no qual loucura e criminalidade se associam e colocam o problema de suas relações, não é o homem da pequena desordem cotidiana, a pálida silhueta que se move nos confins da lei e da norma, mas sim o grande monstro. No século XIX, a psiquiatria do crime se inaugurou por uma patologia do monstruoso. (FOUCAULT, 1978 a, p. 7 - Grifo nosso).

Este louco e, por isso criminoso, deverá ser, definitivamente, afastado da sociedade. E é este 'monstro' que as pessoas, de um modo geral, esperam encontrar para além do portão de ferro do $\mathrm{MJ}$.

paranoico conclamado, parcial ou completo. Filho das calçadas de Torino, o abandono, a miséria fazem dele um tipo de delinquente social e numa posterior etapa, um louco social. Não faltam, porém as características congênitas. Nasceu de sete meses de pais imorais. O ambiente e a predisposição são os dois fatores deste produto misto de vagabundo, de desequilibrado e de ladrão. E de ladrão tem também verdadeiramente a fisionomia falsa e untuosa, as mãos magras e longas, o caminhar indolente. Do ponto de vista psicopático é um paranóide que conserva o poder da lógica.” (Tradução nossa). 
Sabe-se que é comum, sob certas circunstâncias, as pessoas qualificarem outras pessoas como perigosas, especialmente aquelas que praticam atos considerados impróprios à ordem social. São os indivíduos que cometem crimes, muitas vezes considerados hediondos, e que parece evidente à sociedade atribuirlhes um alto nível de 'periculosidade', justificando o clamor pelo uso de práticas punitivas e de isolamento rigorosos a serem impostos a eles. Parece não haver dúvida no uso do termo 'periculosidade' nestes casos: ele é aplicado às pessoas que cometem delitos, em sua plena capacidade de entendimento e ação: são os chamados criminosos comuns. Entretanto, o termo periculosidade aparece à época e por consequência dos crimes que mencionamos no início deste capítulo, remetidos a uma conotação patológica, acrescentando-o um novo aspecto conceitual: a periculosidade passa, agora, a ser entendida também como uma característica intrínseca ao indivíduo. Cria-se então a figura do sujeito ‘intrinsecamente perigoso', não mais aquele eventual ou circunstancialmente perigoso - o criminoso comum -, mas o ‘inerentemente perigoso’. É como se o louco já viesse, desde sempre, determinado por uma periculosidade; é como se o louco fosse potencialmente capaz de cometer atos criminosos (Foucault, 1978 a).

Surge, assim, uma preocupação em demonstrar a existência da loucurahomicida e da importância em ter que controlá-la. Mas de que maneira isto deveria ser feito? Inicialmente demonstrando que nos limites últimos da loucura, lá está presente o crime, ou seja, por trás de um louco oculta-se sempre um criminoso. Ora, era preciso não somente punir e transformar esse indivíduo, como também proteger a sociedade de seus instintos obscuros e inexplicáveis. Assim, a este louco-criminoso, designado como 'inimputável', só resta a internação compulsiva em manicômio judiciário. Aquele que, inscrito como sujeito perigoso, deverá ser afastado do convívio social como forma de se defender a sociedade, e a quem deverá manter-se encarcerado com propósitos curativos e como estratégia de transformação de sua essência mesma.

Contudo, não estou interessada, no momento, em deter-me na construção histórica do conceito de periculosidade, mas tão somente em tentar situá-la em nosso panorama, a fim de entender seus efeitos sobre o paciente inimputável. O conceito de perigo surge, segundo Heleno Fragoso, com o positivismo criminológico. 
A periculosidade é um juízo de probabilidade que se formula diante de certos indícios. Trata-se de juízo empiricamente formulado e, portanto, sujeito a erros graves. Pressupõe sempre, como é óbvio, uma ordem social determinada a que o sujeito deve ajustar-se e que não é questionada (FRAGOSO, 1984).

A questão da periculosidade se apresenta muito bem colocada - apesar de sub-repticiamente - nos laudos de Pierre Rivière ${ }^{24}$, onde os alienistas usam-na como argumento de justificação para a existência de instituições próprias ao tratamento e reclusão dos doentes mentais no início do século XIX. Assim Castel se refere a ela: "um certificado médico [...] controlado pela possibilidade de uma inspeção judiciária, vai poder detectar estados potencialmente perigosos” (Castel, 1977, p. 275). Dito de outra maneira, a periculosidade é definida como probabilidade de que novos crimes sejam praticados; ela é uma categoria cuja função é a de demonstrar os níveis individuais de propensão ao crime. Para alguns juristas, a periculosidade criminal traz consigo a idéia de que o louco-infrator, motivado por apetites e impulsos que lhe são próprios, certamente irá cometer novos ilícitos. Torna-se muito clara essa idéia, ao observarmos as conclusões nos laudos de alguns profissionais do campo psicojurídico, quanto à certeza de reincidência do estado de perigo por parte do paciente inimputável. É como se, uma vez diagnosticado como perigoso, perigoso ele sempre seria.

Não resta dúvida de que se trata de um juízo sobre o comportamento futuro do indivíduo. Segundo Heleno Fragoso, está-se diante de uma ficção jurídica, pois não existe justificação científica do conceito de periculosidade, mas sim, “um caráter profético da noção de estado perigoso” (Fragoso, 1984). Portanto, ela se estabelece probabilisticamente, sendo, por sua própria natureza, de caráter relativo. Concordamos com a idéia de que "a noção de periculosidade está indissociavelmente ligada a um certo exercício de futurologia pseudocientífica” (Rauter, 1997, p.73).

O princípio da presunção de periculosidade penaliza, portanto, o loucocriminoso pelo o que é, e não pelo crime que ele cometeu. A medida tem como seu principal objetivo dominar o indivíduo, e não apenas o seu ato: é a loucura que é julgada e condenada. No entorno da noção de periculosidade pode-se

\footnotetext{
${ }^{24}$ Eu, Pierre Rivière, que degolei minha mãe, minha irmã e meu irmão (1977b). Estamos nos referindo ao caso - compilado por Michel Foucault - de Pierre Rivière, jovem de 20 anos que, em 1835, assassinou sua mãe, sua irmã e seu irmão, todos a golpes de foice. Neste livro, Foucault segundo ele próprio diz -, teve como objetivo essencial, fazer aparecer a engrenagem médica e jurídica que cercou a estória.
} 
observar com clareza uma rede de relações que envolvem saberes e práticas, que acabam por atuar no sentido da formação de determinadas subjetividades: a saber, o sujeito perigoso, como já mencionado no início desse capítulo.

Ora, não pareceria absurdo constatar que - no consenso popular -, é exatamente esse sujeito que se espera encontrar para além dos portões de ferro batido do MJ. Falávamos, anteriormente, como a opinião pública considera estas pessoas inerentemente perigosas. Da mesma forma, o sistema penal sempre partiu da presunção de periculosidade desses pacientes, entendendo-os também como indivíduos perigosos e, por este motivo, os mesmos deveriam ser alijados do processo social. O dispositivo do internamento aparece, então, como a única saída possível.

Como nos mostra Michel Foucault, a psiquiatria sempre funcionou, a partir do século XIX, como mecanismo e instância de defesa social. Os questionamentos do poder judiciário dirigidos a ela preocupavam-se em saber se tais indivíduos eram perigosos e se seriam curáveis. Questionamentos, segundo o autor, isentos de significação, mas "que têm um sentido muito preciso a partir do momento em que são feitos a uma psiquiatria que funciona essencialmente como defesa social ou, para tomar os termos do século XIX, que funciona como 'caça aos degenerados’. E o degenerado é aquele que é portador de perigo”. (Foucault, 2001, p. 404).

Isto mostra como a psiquiatria, que deveria ater-se à doença, passa a funcionar como um dispositivo de ‘caça ao perigoso':

A psiquiatria não funciona - no inicio do século XIX e até tarde no século XIX, talvez até meados do século XIX - como uma especialização do saber ou da teoria médica, mas antes como um ramo especializado da higiene pública. Antes de ser uma especialidade da medicina, a psiquiatria se institucionalizou como domínio particular da proteção social, contra todos os perigos que o fato da doença, ou de tudo o que se possa assimilar direta ou indiretamente à doença, pode acarretar à sociedade. Foi como precaução social, foi como higiene do corpo social inteiro que a psiquiatria se institucionalizou (FOUCAULT, 2001, p. 148. Grifo nosso).

Nessa medida, o campo psiquiátrico se obstinou em reivindicar como loucos aqueles que até então ele tinha considerado como simples criminosos, tão somente pela ambição de conseguir a sua autonomia e a conquistar uma modalidade de poder que viria a se expressar através dos dispositivos de controle. 
Dispositivos estes, implementados sob as formas de higiene pública e de defesa da sociedade, como também expressos pelo saber do médico, o único a poder avaliar não somente o motivo do sujeito, mas associá-lo à sua 'história de vida', integrando o ato à conduta global do sujeito.

Neste sistema específico de encarceramento iremos, em capítulo posterior, apresentar e discutir a utilização, tanto pela psicologia quanto pelo direito, dos dispositivos travestidos de cientificidade, que pretendem aferir o normal e o patológico.

Portanto, é claro o objetivo da intervenção da medicina mental na instituição penal, a partir do século XIX, como conseqüência do ajustamento de duas necessidades que decorriam do funcionamento da medicina, tanto como higiene pública, quanto como punição legal como estratégia de transformação individual. Assim, os manicômios judiciários tornam-se lugar ideal para se isolar o sujeito portador de periculosidade e local propício para ‘corrigi-lo’. Surge, então, como espécie de punição para esses sujeitos, uma modalidade penal que iremos agora problematizar.

Como se sabe, os chamados pacientes inimputáveis encontram-se incursos nas penas do Art.26 do Código Penal. Entenda-se com isso que o sujeito é absolvido da pena, mas permanece privado de sua liberdade. Nestes casos, impõese o estabelecimento de uma modalidade penal denominada 'medida de segurança' - mecanismo de defesa social contra os indivíduos perigosos - que, na verdade, se apresenta sob o disfarce de sanção terapêutica. Segundo argumenta Cruz, “em sua gênese a medida de segurança surgiu para segregar os incorrigíveis - traduzindo uma idéia pura de prevenção especial negativa (de inocuização), sempre com o fito de se auferir proteção social” (Cruz, 2009).

Continuando, Brito e Souto (2007) vai mais além:

Mister reconhecer às medidas de segurança o status de condenação penal, que só se diferencia da pena por aspectos negativos: a ausência de limite máximo e brutal desproporcionalidade entre a sanção e a lesão jurídica causada desvelando a idéia falaciosa de sanção benévola sob o cunho de tratamento.[...] nada justifica racionalmente a diferenciação nominativa entre penas e Medidas de Segurança: essas nada mais são do que penas de efeitos dolorosos, deteriorantes e estigmatizantes, e assim devem ser chamadas (BRITO E SOUTO, 2007, p. 583). 
De acordo com esta interpretação, o que se pode concluir é que a medida de segurança nada mais é senão uma medida punitiva, restritiva de direitos, tal qual a condenação penal. Contudo, pior: pelo simples motivo de estar travestida de uma aura humanística de tratamento.

Foi no Código Penal de 1940, que o instituto ganhou roupagem verdadeiramente jurídica (Cruz, 2009). A medida de segurança vem amparada em um grande equívoco, no mínimo, ambíguo: ela absolve, mas também, em compensação, interna! Com efeito, ela produz um nefasto processo de segregação e de exclusão, preocupada tão somente em manter o inimputável bem afastado do meio social. Este sujeito é, portanto, encaminhado para tratamento em hospital de custódia e tratamento psiquiátrico, nome que vem apenas disfarçar o que é, de fato, conhecido como manicômio judiciário, o 'final da linha'.

Com o Código Penal de $1940{ }^{25}$ o critério da periculosidade passa a orientar as decisões judiciais e é criada a figura da medida de segurança. Deste modo, elas surgem como medidas especiais para aqueles denominados doentes mentais perigosos. E por serem perigosos não se aplica o clássico critério de solução da justiça in dubio pro reo, mas sim, o in dubio pro societate. Ou se preferirmos dizê-lo de forma mais clara: sentencia-se o indivíduo a uma medida de segurança por tempo indeterminado, visando, com isso, a 'proteção da sociedade'. A fim de defender a sociedade dos inevitáveis riscos advindos do louco-criminoso, cria-se uma sanção que tem por objetivo principal, diminuir e controlar o risco de criminalidade desse sujeito em questão.

Juridicamente a medida de segurança é formulada como uma medida preventiva que visa o futuro, e por isso é clara a sua associação à noção de periculosidade. Isto significa dizer que a medida de segurança não é determinada com base no crime, mas no suposto nível de perigo presente no individuo. Enganam-se os que pensam ser esta modalidade penal, uma medida de tratamento. Ela é, na realidade, uma sanção penal, tal qual a pena em si. E com um agravante: se mostra ainda mais aflitiva do que a pena, dado o seu caráter indeterminado. Além disso, enquanto os condenados sujeitos à pena fazem jus a todos os direitos inerentes à execução penal - livramento condicional, progressão de regime e

\footnotetext{
${ }^{25}$ O Código Penal de 1940 determina em seu art.97, § $1^{\circ}$ que: "A internação, ou tratamento ambulatorial, será por tempo indeterminado, perdurando enquanto não for averiguada, mediante perícia médica, a cessação de periculosidade” (Grifo nosso).
} 
indulto -, aos inimputáveis, contudo, estes direitos não são aplicáveis. Não seria, portanto exagero afirmar que se punem aqueles que são, declaradamente, isentos de pena.

Assim sendo, a internação podendo tornar-se de caráter perpétuo, isola o paciente do contato com o mundo extramuros, deixando-o à mercê da avaliação de uma equipe de 'especialistas’ que decidirá por sua vida futura. Esta decisão se baseia nas conclusões dos laudos e pareceres que deverão atestar, ao longo da internação, o grau de 'periculosidade’ deste indivíduo, concluindo se ele estará apto ou não para voltar ao convívio social. Novamente citamos Fragoso em sua clara e objetiva fundamentação:

Em boa verdade, o juízo de periculosidade é formulado precariamente pelo juiz, de forma empírica, incerta e intuitiva, mais semelhante a uma suspeita que a um diagnóstico positivo. [...] A verdade é que ninguém sabe quando a periculosidade existe ou não existe, partindo do exame da personalidade do agente. [...] Em suma, o que se tem a dizer é que não há métodos científicos para determinar a periculosidade, que é um conceito vago e indeterminado, sendo o procedimento judicial de sua verificação fundado na intuição do juiz, com critérios de evidente racionalismo (FRAGOSO, 1984, p. 12).

Enquanto isso, só resta ao paciente aguardar pela palavra dos especialistas. Durante esta longa espera ele tende a se institucionalizar, não somente pelos efeitos provocados pelo prolongado tempo de enclausuramento, mas também como uma maneira de sobreviver dentro da instituição mesma. Ele se vê tanto acomodado às normas estabelecidas, quanto se vê contaminado e invadido por elas: os pacientes tendem a se tornar passivos diante da vida e cronificados em sua doença.

Na verdade, ao ser considerado pelo saber médico-jurídico um indivíduo socialmente perigoso, o paciente ficará internado até que seja averiguada e cessada a sua alegada periculosidade ${ }^{26}$. Para tal, faz-se mister que ele preencha uma série de requisitos que estabelecem o 'correto' modo de viver do loucocriminoso. Tal qual a prisão, o paciente deverá manter um bom comportamento, buscar uma ocupação dentro da instituição, mostrar-se disponível a qualquer solicitação por parte dos profissionais, ou seja, viver sob o controle de uma ameaça permanente (Castel, 1977).

\footnotetext{
${ }^{26}$ O nível de periculosidade do paciente inimputável é aferido a partir dos chamados 'Laudos de Cessação de Periculosidade’, elaborados por peritos forense, lotados no Setor de Perícias do MJ.
} 
Sem dúvida nenhuma, baseando-se no infindável tempo de internação transcorrido e na própria letra da Lei - transcrita na última nota de rodapé -, é correto afirmar que, na maioria dos casos, a medida de segurança nada mais é do que uma condenação à prisão perpétua. Aliás, Franco Basaglia nos brinda com uma de suas perspicazes intervenções ao afirmar que, manicômio ou prisão são situações intercambiáveis, pois "podemos tomar um preso e colocá-lo no manicômio ou tomar um louco e metê-lo na prisão” (Basaglia, 1982, p. 45). Ambos servem para marginalizar e manter afastado aquele que é excluído da sociedade.

Voltando nossa análise especificamente para a questão da medida de segurança, não seria errôneo sustentar que a mesma, gerada sob a influência da escola criminológica positivista, e baseada em conceitos médicos-jurídicos, alastrou-se pelo século XIX, mantendo-se fiel aos seus preceitos - frágeis e imprecisos - até os dias de hoje. Acreditamos que, enquanto raciocinarmos no sentido de que a medida de segurança esteja diretamente vinculada ao conceito jurídico de periculosidade, não conseguiremos enxergar o paciente como sendo alguém passível de tratamento, mas sim como um sujeito passível de punição.

O absurdo paradoxo com referência a essa medida nos parece semelhante à natureza ambígua presente na instituição mesma. Tal caráter dúbio - de prisão e hospital - é uma das particularidades mais flagrantes verificadas na instituição. Isto pode ser observado desde o seu aspecto físico - com grades, trancas e cadeados -, até em relação à ambivalência incrustada na própria equipe e no paciente mesmo: alguns aludem a si próprios como sendo 'internos' - ao invés de pacientes -, e usam a palavra prisão em referência a hospital. Talvez possamos constatar que a estrutura ambivalente que sustenta o MJ, reflete a própria ambigüidade do conceito de medida de segurança: esta se encontra erroneamente ligada ao conceito jurídico de periculosidade, ao invés de estar associada ao conceito psíquico de transtorno mental (Ibrahim, 2000).

Como vemos, o MJ é atravessado por peculiaridades bastante contraditórias: a instituição parece oscilar entre dois modelos: o modelo jurídicopunitivo e o modelo psiquiátrico-terapêutico. O primeiro vê o sujeito capaz de ser, tanto moral como penalmente, responsabilizado por suas ações. O segundo define o indivíduo, não enquanto sujeito, mas enquanto objeto de seus impulsos e 
desejos, não podendo ser responsabilizado pelos seus atos e nem ser passível de punição.

A prática institucional se mostra perversa quando utiliza a superposição desses dois modelos, caracterizando-se como uma instituição fundada em contradições. Entendam-se aí, como faces da mesma moeda, o direito e a justiça punitiva, a pretensão de justiça e o dispositivo de repressão (Carrara, 1998). E é nesta imbricação que se produz o paciente inimputável: sob a ambivalência da instituição e sob o olhar do profissional que, muitas vezes, sustenta-se sobre verdades absolutas e universais, utilizadas nos laudos e pareceres: trata-se de uma produção técnica de ‘discursos de verdade’.

Reportando-nos à narração de um caso clínico datado de 1898, pelo médico psiquiatra Lorenzo Mandalari, diretor do então Manicomio Privato de Messina, podemos comprovar estes discursos, não somente através da descrição da anamnese do paciente - “Non conoble mai la madre, che fu uma prostituta.[...] giovanetto, venne rinchiuso in uma casa di correzione, donde iscì per prendere la via del cárcere.[...].Tatuaggio all'avambraccio sinistro: un A ed um $D^{27}$ (p. 101102) - como também na de seu diagnóstico:

Deficienza morale: delinquenza occasionale in individuo degenerato, predisposto alla pazzia ed all'epilessia. È um tipo di degenerato congenito, maturato in um ambiente propizio al delitto, ma al delitto spicciolo e mite, il piccolo furto per vivere, egli dice, e per non lavorare, diciamo noi. Ad ogni modo, è un delinquente ed um pazzo per ragioni molteplici, nelle quali figura, non in seconda línea, Il fattore sociale. (MANDALARI, 1901, p. 103) ${ }^{28}$.

Mais de um século depois, continuamos a nos deparar - ainda que com menor frequência - com laudos e exames bastante semelhantes...

Não obstante o isolamento continue sendo um dos objetivos das instituições - quaisquer que sejam elas, o século XIX, caracterizado pelas grandes revoltas populares, traz uma nova ameaça: o aumento da riqueza de alguns e, não

\footnotetext{
27 "Não conhece mais a mãe, que foi uma prostituta. [...] muito jovem, foi preso em uma casa de correção, de onde saiu para tomar o caminho do cárcere. [...] Tatuado no antebraço esquerdo: um A e um D" (Tradução nossa).

28 "Deficiência moral: delinquência ocasional no individuo degenerado, predisposto à loucura e à epilepsia. É um tipo de degeneração congênita, desenvolvida em um ambiente propício ao delito, mas ao delito suave, brando; o pequeno furto para viver, ele diz, e não para trabalhar, dizemos nós. De qualquer modo, é um delinquente e um louco por razões múltiplas, no qual figura o fator social” (Tradução nossa).
} 
por acaso, o desemprego de muitos outros. Cresce a indigência e polemizam-se as discussões sobre o comportamento infrator. Com isso, surgem as tentativas de prevenção a novas reincidências, justificando-se um maior controle e punição da população transgressora. Como advertiu Foucault em certa ocasião:

Toda a penalidade do século XIX passa a ser um controle, não tanto sobre se o que fizeram os indivíduos está em conformidade ou não com a lei, mas ao nível do que podem fazer, do que são capazes de fazer, do que estão sujeitos a fazer, do que estão na iminência de fazer. [...] Nasce a noção de periculosidade que significa que o individuo deve ser considerado pela sociedade ao nível de suas virtualidades e não ao nível de seus atos; não ao nível das infrações efetivas a uma lei efetiva, mas das virtualidades de comportamento que elas representam (FOUCAULT, 2005, p.85).

As instituições de correção, dentre elas, os manicômios judiciários, são agora a forma de poder lateral que têm como função, não mais punir as infrações cometidas dos indivíduos, mas sim, corrigir suas ‘virtualidades ${ }^{29}$. Trata-se de um tipo de sociedade disciplinar, onde o controle é a peça fundamental:

Entramos assim na idade do que eu chamaria de ortopedia social. Trata-se de uma forma de poder, de um tipo de sociedade que classifico de sociedade disciplinar por oposição às sociedades propriamente penais que conhecíamos anteriormente. É a idade de controle social (FOUCAULT, 2005, p. 86).

Embasando-nos em argumentos do autor, podemos reafirmar que os conceitos de 'periculosidade' e de 'virtualidade' parecem imbricados numa mesma engrenagem: eles ilustram a passagem do ato ao ser, do que se fez ao que se é. De acordo com essa perspectiva, agora não mais se controla o que o indivíduo fez, mas aquilo que ele pode vir a fazer, aquilo que se supõe ser ele capaz de fazer.

Com efeito, não se trata apenas de colocar em evidência o individuo como sujeito do ato, mas também como o sujeito perigoso prestes a cometer a ação infracional novamente. Não há saída para ele: uma vez louco-criminoso, para sempre louco-criminoso.

E, há décadas, o seu paradeiro tem sido o mesmo: em 1921 foi inaugurado o Manicômio Judiciário com o objetivo de retirar da Seção Lombroso - no interior da Seção Pinel do Hospício Nacional -, os pacientes considerados perigosos. A

${ }^{29}$ O termo 'virtualidade', na concepção foucaultiana, significaria algo que está prestes a se atualizar. 
partir de então, o MJ passou a receber os 'loucos-criminosos' encaminhados pela Justiça do antigo Distrito Federal. Em 2012, quase um século depois, o MJ se mantém como o lugar subordinador onde se faz possível um melhor desdobramento de estratégias de intervenção psiquiátrica, maximizadas por tecnologias de saber/poder (Castel, 1978). Não se pode negar que, os manicômios judiciários, tal como se encontram implicados no interior da engrenagem dos 'jogos de verdade’, sejam, de fato, o final da linha destinada àqueles - segundo a visão de Michel Foucault -, de quem a sociedade precisa se defender. 


\section{3}

\section{Por que Foucault?}

Nosso terceiro capítulo inicia-se com uma indagação: 'Por que Foucault'? Primeiramente porque ele nos fala do lugar mais fundo da sujeição: a exclusão. Segundo José Carlos Bruni "é para lá que Foucault nos conduz; é de lá que Foucault fala” (1989, p. 2010). É a partir desse fundo que ele vai fazer emergir os processos de discriminação do delinqüente, e de patologização e confinamento do louco. Foucault não está interessado - como tantos outros autores estiveram - em estudar a loucura, mas, ao contrário, em buscar quais as condições de possibilidade que fizeram transformar o louco em doente mental. Eis um dos motivos que o fazem singular.

Por que Foucault? Por sua reflexão e visão crítica em relação aos postulados teóricos científicos com relação aos saberes, especialmente, no que diz respeito à loucura. Por aprofundar-se no estudo das "engrenagens do submetimento, da fabricação dos sujeitos submetidos” (Eribon, 2004, p. 10). Por questionar e estranhar as ditas verdades absolutas. Por optar em problematizar o presente, ao invés de naturalizá-lo. Por um gosto pelas desmistificações, pelo espírito resistente às evidências e às constatações verificáveis, pela desconfiança às falsas continuidades, por ter pensado a história de maneira singular, em lugar de legitimar o que já se sabia. Por valorizar a surpresa, o acaso, a contingência da história de vidas simples, singulares, de ‘homens infames’. Por não se afirmar sob nenhuma posição dogmática, e por duvidar sempre de tudo que é colocado como definitivo, natural, inquestionável. Por não temer os paradoxos nem as contradições. Pela sua originalidade em "não transformar nossa finitude em fundamento de novas certezas” (Veyne, 1985, p.37). Por um novo jeito de olhar...

Por que Foucault? Porque é a partir de suas ideias sobre as condições sócio-históricas do aparecimento dos saberes a respeito do homem, que ele nos leva a pensar de que maneira se constituem as noções de loucura, de doença mental e dos dispositivos ligados a elas. Não só por isso, como também, pelas problematizações provocadas por ele, que nos conduzem a uma compreensão mais clara sobre as questões relacionadas à psiquiatria, ao direito, ao hospital, ao asilo, 
e aos demais temas que propusemos a estudar e a desenvolver como matéria nesta dissertação.

Michel Foucault, portanto, é o autor com quem nos identificamos e com quem concordamos ser possível ousar questionar o campo do instituído, rompendo com seus antigos paradigmas. Pretendemos discutir sobre isso, trazendo uma outra interrogação: de que forma, efetivamente, é possível produzirse conhecimentos capazes de se insurgirem contra aquilo que os saberes sobre o homem acudiram a gerar e a aprimorar? Em outras palavras e de maneira mais específica: como seria possível romper com tais paradigmas quando nos referimos às instituições totais- tais como o asilo e a prisão, só para citar algumas - que se encontram amparadas e apoiadas em saberes secularmente impostos pelas ciências do homem?

Pensamos que nossas indagações poderão ser discutidas ao longo desse trabalho, amparadas nos ensinamentos de Michel Foucault que, como analisa Heliana Conde Rodrigues (2002), faz história praticando raridades, provocando inquietações, pois se trata de um 'historiador de problemas'. Foucault parece vir para romper com o que está posto, romper com o naturalizado, com as continuidades, com o definitivo. Ele, de fato, parece vir, parafraseando Paul Veyne (1990), para ‘sacudir’ a história.

\section{1}

\section{O Método Arqueogenealógico de Michel Foucault}

Acreditamos que, ao inventar um novo estilo de pensar no campo mesmo da filosofia - através da construção de seu método arqueogenealógico ${ }^{30}$-, Foucault nos mostra que as evidências, as certezas, as naturalizações são, de fato, saberes produzidos e, assim sendo, podem ser transformados.

Detendo-nos por uns instantes especificamente no que tange à loucura, podemos constatar que a sustentação foucaultiana baseia-se na idéia de que a loucura é uma construção histórica e cultural, rompendo, assim, com a leitura

\footnotetext{
${ }^{30} \mathrm{O}$ método arqueogenealógico de Michel Foucault pretende descrever a constituição das ciências a partir de uma inter-relação de saberes através da análise das relações de poder. Ou seja, a arqueologia procura buscar quais os conjuntos de regras que definem um saber; enquanto a genealogia busca o ‘como' e o 'por que' desses saberes se transformarem, isto é, quais as relações de forças que os fizeram mudar.
} 
naturalista que, até então, lhe era conferida. Através do método arqueogenealógico o autor analisa em que práticas o conceito de loucura foi gestado, iniciando o processo analítico de trás para frente, isto é, a partir da história do presente até encontrar uma descontinuidade histórica. Desta forma, já não se pode mais olhar a loucura como algo natural nem contínuo, mas sim como algo que só existe no momento em que é postulada historicamente e dentro de um determinado contexto.

Para o autor, a ideia de arqueogenealogia remete à pesquisa detalhada de 'como' surgem determinadas regras a respeito de determinado saber, e 'por que' estes saberes se transformam. Dito de maneira mais simplificada, a arqueologia trata das condições de possibilidade para a produção de saber, enquanto que a genealogia trata das relações de poder. Como Foucault leciona, os fatos históricos variam a cada tempo e se impõem como verdades, assim como os diferentes conceitos de loucura foram impostos através de discursos tidos como verdadeiros ao longo dos tempos. O que Foucault tentou fazer em sua História da Loucura foi procurar balizar qual o tipo de poder que a razão tentou exercer sobre a loucura no século XVII, como ela emergiu na história e como foi construída. Para ele, a loucura erigiu-se pelo o que se disse a respeito dela (Machado, 1981, p. 161).

Neste ponto, a diferença entre Foucault e os epistemólogos franceses da época se situa no fato de que ele não toma a emergência do acontecimento como uma verdade, mas tão somente como um problema. Daí ele ser conhecido com um 'historiador de problemas'. Segundo ele, é necessário se fazer uma história das problematizações, ou seja, a história da maneira pela qual as coisas produzem problemas (Calderon, 2003). Partindo de uma problematização do presente e analisando arqueogenealogicamente as descontinuidades da história, Foucault levanta pertinentes questões: quais as condições de possibilidade que fizeram, em uma determinada época, com que a loucura fosse pensada, inicialmente como desrazão, para depois ser considerada como alienação? A quem interessava que ela assim fosse entendida? Quais as relações de poder que produziram estes discursos, estas práticas de subjetivação, enfim, esses saberes? Acompanhando Foucault, pensamos que a loucura - assim como a delinquência - há que ser vista de maneira circunstanciada, e não de forma linear e ingenuamente naturalizada. 
Foucault indicava como as diferentes leituras sobre a loucura se inscreviam em pressupostos filosófico, moral, religioso e científico que regulariam as práticas sociais sobre ela, e que era isso que deveria ser colocado em evidência numa arqueologia da loucura. Dito de outra maneira, o que Foucault ressaltou foi como a experiência da loucura foi objeto de silêncio e de exclusão social como seu correlato; necessário seria realizar a arqueologia desse silêncio (BIRMAN, 2011).

A análise epistemológica foucaultiana caracteriza-se por cortes, rupturas, e pela noção de descontinuidade histórica, que é um princípio que mina as noções filosóficas da essência imutável do homem. Ela permite transformar discursos considerados universais, na medida em que possibilita a análise do momento de surgimento e de desaparecimento de uma forma de saber e das práticas a ele atreladas.

Se trouxermos novamente à baila a questão do 'Grande Internamento' ocorrido no século XVII, poderemos entender melhor a noção de descontinuidade, que constitui um dos elementos fundamentais do pensamento de Foucault. Como foi comentado no Capítulo 2, depois de ser internado junto aos socialmente indesejáveis, o louco, agora despossuído de razão, é extraído daqueles pobres e libertinos e passa a ser confinado não mais no hospital geral do 'grande enclausuramento', mas, sim nos asilos. Deu-se aí uma ruptura, um importante acontecimento, segundo Foucault, gerando novos saberes. Ou seja, extraiu-se do louco certos saberes que passam a fazer parte de um corpo de conhecimento, de um tipo de especialidade, qual seja, a psiquiatria. Esta, por sua vez, provida de um saber sobre a loucura e movida por relações de poder, transforma o louco em doente mental: transporta-o da nau ao asilo. E, assim, vão se produzindo - através de sequências, de rupturas e de descontinuidades -, saberes sobre o louco e, consequentemente, construindo-se discursos que se legitimam como verdades absolutas sobre o objeto pesquisado. Agora não é mais o louco que fala da sua loucura, mas é o psiquiatra que discursa sobre o doente mental, através de enunciados de verdade.

Deste modo, Michel Foucault, através de seu método arqueogenealógico, procura pesquisar como determinado saber foi sendo construído historicamente e que práticas produziram esse saber; quais os jogos de linguagem - em sua forma discursiva - e quais os jogos de verdade que, a partir daí, foram produzindo certos jogos de saber. São essas as problematizações que iremos tratar. 
E para terminar, perguntamos mais uma vez 'por que Foucault'? Simplesmente porque ele tinha o dom de lidar com toda a imbricação entre as relações de poder, ainda que discordasse de muitos intelectuais de sua época. Parece-nos que Michel Foucault soube caminhar por searas adversas e opostamente contrárias às suas, sem, no entanto, agredir ou desqualificar aqueles que o atacavam.

Ele pôde, enfim, lutar estrategicamente, resistindo sempre!

\section{2}

\section{Os pilares foucaultianos e a questão do sujeito}

Acompanhando Foucault, acreditamos que falar de subjetividade é falar de processo, de modos de existência (Foucault, 1995 a), de maneiras de dizer o mundo. E, para se discutir a problemática de como se conhece o mundo, a linguagem faz-se fundamental.

Na passagem do século XIX para o século XX, a interrogação sobre a natureza da linguagem e a maneira como ela fala do real, aparece como uma matéria central na filosofia e em outras áreas do saber, sendo problematizada por correntes teóricas distintas. A questão da linguagem, portanto, se revela como centro de interesse no pensamento contemporâneo. Segundo Danilo Marcondes, a sua análise torna-se “a estrada real para o tratamento não só de questões filosóficas, mas de questões dos vários campos das ciências humanas e naturais no pensamento contemporâneo” (Marcondes, 1997 p. 254). A linguagem é fundamental para se discutir a questão de como se dá o conhecimento, de como se conhece o mundo.

Ela pode ser vista sob dois aspectos: no primeiro deles, a linguagem é entendida como representação do real, enquanto que no segundo, ela seria construída na realidade mesma. No primeiro aspecto, o da linguagem entendida como representação do real situa-se, por exemplo, a visão objetivista e universalista de Noam Chomsky (2006), que entende a linguagem como módulo da mente - o cérebro teria vários módulos e um deles seria o da linguagem -, adotando uma posição claramente cartesiana. Para o autor, existe uma estrutura de linguagem pronta, assim como existe uma realidade que se representa. Semelhante 
a este ponto de vista, o empirismo lógico - de inspiração cartesiana -, traz como seu representante o filósofo Ludwig Wittgenstein (1889-1951), uma das maiores fortunas da Viena do final do século XIX. Foi ele quem colocou a linguagem no centro da reflexão filosófica, deixando de figurar apenas como um meio para nomear as coisas ou transmitir pensamentos. O primeiro ${ }^{31}$ Wittgenstein entende a linguagem como um espelho do mundo, capaz de representá-lo. Já no segundo aspecto - o da linguagem, não mais como representação do real, mas como construindo conceitos a partir de um contexto cultural especifico -, ela será problematizada sob o ponto de vista da pragmática, tendo o segundo Wittgenstein como um dos principais autores e pesquisadores do tema.

A perspectiva objetivista/representacional se ocupa em construir uma linguagem lógica para representar a realidade. Ou seja, para a visão objetivista existe uma realidade-em-si que independe da linguagem e que pode ser representada corretamente através da razão. René Descartes é um dos filósofos que apresentam uma maneira análoga de entendimento sobre a noção de realidade do ponto de vista objetivista. Segundo Marcondes (2000), a obra filosófica de Descartes adota uma posição dualista acerca da natureza do corpo e da alma, dando ênfase à subjetividade na análise do processo do conhecimento. Uma de suas obras mais importantes, Meditações Metafísicas, escrita e publicada pela primeira vez em 1641, é composta por seis meditações, nas quais Descartes coloca em dúvida toda crença que não seja absolutamente certa, real, factível, e a partir daí procura estabelecer o que é possível se saber com segurança. Ele acreditava ser necessário colocar previamente em dúvida tudo o que existia, instituindo o método da dúvida: só se pode dizer que existe aquilo que puder ser provado, sendo o ato de duvidar, indubitável.

Isto significaria dizer que, tudo que resta ao homem é, precisamente, a dúvida. E sendo a dúvida uma forma de pensamento, conclui-se que duvidar é pensar. E se há pensamento, há um ser pensante. Assim, Descartes chegou à sua equação “penso, logo existo”. Contudo, a existência do ser pensante traz apenas a certeza de um mundo interior, de uma subjetividade, de uma realidade interna. Por

\footnotetext{
${ }^{31} \mathrm{O}$ pensamento de Wittgenstein é geralmente dividido em duas fases. Na primeira fase o filósofo entende a linguagem como uma simples representação do real, enquanto que em sua segunda fase, ele a considera dentro de um contexto cultural especifico, fundamentando-a sob o ponto de vista da pragmática.
} 
outro lado, no que diz respeito ao mundo exterior, sobre o mundo natural, não se tem nenhuma certeza, permanecendo, portanto, a dúvida.

A concepção cartesiana entende a mente como um espelho da natureza que, através da razão, forma representações que podem ser corretas ou não. Consequetemente, Descartes pressupõe a existência de uma realidade-em-si que pode ser representada corretamente pelo sujeito. A partir do movimento filosófico inaugurado por ele, as principais discussões da ciência acerca das questões psicológicas focam-se em modelos introspectivos: a ciência se convenceu de que, para conhecer o mundo externo, devia-se investigar detalhadamente o mundo interior, ou seja, conhecedor de seu próprio eu interior e senhor da razão, o sujeito era capaz de explicar a realidade. Consolidava-se no domínio da ciência, a tão conhecida dicotomia corpo/alma proposta por Platão que, assim como Descartes e outros filósofos, viam a alma como o lugar privilegiado da razão, da sabedoria e da ciência. Por mais de dois séculos esta filosofia da consciência, dita hegemônica, foi o principal palco dos debates científicos.

Consoante à afirmação cartesiana de que o pensamento representava a realidade-em-si, o primeiro Wittgenstein, adotou a tese de que a linguagem era representativa, uma cópia do real. Em seu único livro publicado em vida, o Tractatus logico-philosophicus, Wittgenstein considera a linguagem como uma figuração da realidade que tem como objetivo, tratar de descrever como é o mundo. Wittgenstein propõe, em sua obra, um tipo de linguagem ideal, válida universalmente. Sua intenção é definir a natureza da linguagem e sua relação com o mundo, descrevendo-o através de um sistema de representação perfeito. A pergunta feita no Tractatus, “o que é a linguagem?”, reflete a sua preocupação em buscar a essência da linguagem, a sua origem ou princípio.

Partindo do pressuposto de que a função da linguagem é a de representar o mundo, Wittgenstein foi levado a problematizar a realidade, constatando a sobreposição e a estreita ligação entre linguagem e mundo, chegando mesmo a considerar a linguagem como um espelho do mundo, assemelhando-se à proposição essencialista cartesiana da idéia da mente como um espelho, refletindo a realidade. Assim, é através da lógica que a linguagem espelha a realidade, podendo-se constatar que, para o primeiro Wittgenstein, a função primordial da linguagem é representar o mundo da maneira mais fielmente possível. Ou seja, a 
linguagem deve descrever e analisar exatamente como as coisas são na realidade. A esta visão de linguagem como representação da realidade iremos, mais adiante, contrapor a noção de verdade em Foucault, que traz uma concepção de verdade enquanto um campo de possíveis.

A perspectiva construtivista de realidade sustenta que, contrariamente à visão objetivista/representacional, não existe realidade independente da linguagem: a realidade é sempre significada e produzida pela linguagem, através de práticas sociais. Ela é fruto de uma construção linguística. Parafraseando Veyne, “o objeto não é senão o correlato da prática; ele não existe antes dela. [...] cada prática engendra o objeto que lhe corresponde; não há objetos naturais nem coisas. As coisas, os objetos não são senão os correlatos das práticas” (Veyne, 1990, p.256). . Isto significa dizer que a prática é anterior ao objeto. Foucault, ao problematizar o real, faz referência a uma mecânica, a uma composição do real, ao invés de entender a realidade como representação. O real não é representado, mas construído, produzido. Da mesma forma que o real não existe, mas sim práticas de realização do real, a história é também uma prática de produção do real: um real como acontecimento, como contingência.

Como já foi dito, Wittgenstein adota inicialmente o método tradicional do empirismo lógico -, caracterizado pelo conhecimento científico adquirido pela relação causa-efeito, pela crença na realidade-em-si, pela busca por verdades universais, pelo entendimento da linguagem como cópia da realidade - para, radicalmente tomar como base a visão pragmática, onde a linguagem já não mais é vista como representativa do real. Podemos observar, portanto, que nesta segunda fase wittgensteiniana, o filósofo tenta solapar as bases do pensamento cartesiano pela análise da linguagem, demonstrando que a linguagem não é mais entendida como uma forma de representação da realidade, mas ela é, tão somente, anterior a ela ou, melhor dizendo, a linguagem constrói a realidade (Lampreia, 2011). Além disso, sob o ponto de vista da pragmática, tem-se uma concepção da linguagem não só como construção do real, mas também como ação. Assim, podemos considerar que

na visão pragmática, a linguagem passa a ser vista como uma prática social, como uma forma de ação, e deste modo diferentes práticas sociais podem construir diferentes referências ou objetos internos e externos, a partir de uma 'mesma base’. Em outras palavras, é válido dizer que os objetos nunca são dados, mas 
sempre construídos a partir de diferentes significações atribuídas a eles de forma convencionada pelas diferentes práticas sociais (LAMPREIA, 2011).

Contrariamente à visão representacional, agora, na concepção pragmática de linguagem, não há mais a reificação de conceitos universais - o significado é dado pelo uso, pelas práticas sociais -, nem tampouco cabe a noção de verdade absoluta. A visão pragmática procura investigar os diversos usos da linguagem, adotando uma posição histórica e contextualizada. Lembramos - nos da tese central de Foucault: o que é feito, o objeto, se explica pelo que foi o fazer em cada momento da história.

\begin{abstract}
Enganamo-nos quando pensamos que o fazer, a prática, se explica a partir do que é feito. [...] Toda dificuldade vem da ilusão mediante a qual "reificamos" as objetivações em um objeto natural: tomamos um ponto de chegada por um fim, tomamos o lugar em que um projétil vai, por acaso, se esborrachar por um alvo intencionalmente visado. Em vez de enfrentar o problema em seu verdadeiro cerne, que é a prática, partimos da extremidade, que é o objeto, de tal modo que as práticas sucessivas parecem reações a um mesmo objeto, "material" ou "racional”, que seria dado inicialmente. Então começam os falsos problemas dualistas, assim como os racionalismos (VEYNE, 1990, 257).
\end{abstract}

Sem dúvida, pode-se notar que tanto Foucault quanto Wittgenstein têm em comum, não crer em nada além do que singularidades, recusando, ambos, a verdade e a linguagem como adaequatio, mentis et rei ${ }^{32}$. Em sua principal obra as Investigações Filosóficas -, Wittgenstein constata que a linguagem surge como alternativa de explicação de nossa relação com a realidade enquanto relação de significação, e não mais de representação. Esta nova perspectiva abandona uma posição predominantemente semântica para introduzir uma dimensão predominantemente pragmática (Condé, 1998 p. 87). Após a publicação do Tractatus, Wittgenstein resolveu abandonar a filosofia, e nesta época afastou-se de suas ideias iniciais, desenvolvendo uma nova visão de linguagem, agora

não mais voltada para a análise lógica das proposições, mas para 'jogos de linguagem', isto é, para a linguagem tal como usada em textos específicos, por falantes e ouvintes, para fins específicos. A linguagem passa a ser vista então como uma prática social concreta, sendo o significado de termos e expressões linguísticos resultado desta prática (MARCONDES, 2000, p. 165).

\footnotetext{
${ }^{32}$ Conformidade da mente e da coisa.
} 
Com efeito, podemos reafirmar que o significado das palavras é dado pelo seu uso, e não ao contrário, determinado pela sua referência a um objeto no real. Ele é dado por regras normativas. Isto significa dizer que é o social que convenciona o que é, e o que não é aceitável: “as convenções sociais são as próprias regras que definem o sentido da linguagem” (Coutinho, 1994, p. 65). Desta forma - sendo construído pelo uso -, o significado parece não ter uma essência definida, mas, ao contrário, ele se modifica a cada uso que fazemos dele.

É exatamente este uso cotidiano das palavras dentro das mais diversas situações e contextos, que Wittgenstein denominou de ‘jogos de linguagem’ e, adotando a concepção de linguagem como um jogo, inaugura o aspecto pragmático presente na linguagem.

Segundo Marcondes (1997, p. 270-271), os ‘jogos de linguagem' se caracterizam por sua pluralidade e diversidade; novos jogos surgem, outros desaparecem. Para o autor, o uso da linguagem é, portanto, uma prática social concreta. E Condé (1998, p. 87) acrescenta: “[...] e esses múltiplos jogos de linguagem se constituem em verdadeiras formas de vida”. Com efeito, a linguagem está relacionada com uma maneira de viver de uma cultura, com a forma de vida de uma comunidade humana, com suas mitologias, crenças, necessidades e interesses. São estas práticas e formas de vida de uma cultura o que dão significado à linguagem. Como nos ensina Veyne (1990), “a prática não é uma instância misteriosa, um subsolo da história, um motor oculto: é o que fazem as pessoas”.

Pautando-nos na concepção pragmática de linguagem e, assim, entendendo a realidade significada e produzida pela linguagem mesma, através de práticas sociais e, considerando o significado da linguagem, não como sendo determinado pela referência ao real, mas pelo seu uso - que, por sua vez, depende das regras de convenção social de cada contexto -, estaríamos pensando em um sujeito singular. A que sujeito estaríamos nos referindo? Ao sujeito compreendido do ponto de vista naturalista, ou ao sujeito pensado sob a visão antropológica?

Certamente não estamos nos referindo ao sujeito cartesiano, aquele que 'já estava lá', o sujeito entendido como natural, transcendental, a priori, ou seja, o sujeito conceituado de acordo com a visão naturalista. Estamos falando do sujeito que afeta e é afetado pelo seu meio, o sujeito que se modifica e que se reinventa a 
cada contingência de seu processo histórico, o sujeito constituído nas e pelas práticas sociais, situado e contextualizado culturalmente, agindo por razões e intenções, e não por causas.

Estamos nos referindo à visão antropológica de sujeito, com a qual compartilhamos. Apesar de não se rejeitar a idéia de que haja algo de interioridade no sujeito, esta interioridade, contudo, não deve ser entendida como uma essência, como algo imutável, inato ou, como já o dissemos, 'que já lá estava', mas algo que se modifica a cada tempo. Esta interioridade do homem tem uma origem externa e, esse algo externo é construído em uma prática. Reafirmando o pensamento de Foucault, consideramos que o sujeito no mundo, nada mais é do que construção, produção, invenção. A subjetividade é considerada como produto de uma construção social sugerindo-se que, o que hoje é interno, um dia foi externo e social, ou seja, propõe-se que o que somos hoje é fruto de uma construção social linguística, onde se afeta e se é afetado o tempo todo.

Da mesma maneira a noção de sujeito é problematizada em Foucault: tal como a linguagem, o sujeito se constitui no interior das práticas, isto é, o sujeito é produto de múltiplas práticas sociais. Segundo o autor, a subjetividade é pensada como um modo de existência, como processo indissociável da idéia de produção. A subjetividade é, portanto, processo de produção: o eu está em constante transformação, e o homem se constitui pela ação das circunstâncias, pelo encontro com a alteridade, pela forma como ele vivencia as experiências na relação com o outro e consigo mesmo.

O autor aponta para a importância da atitude crítica e da constituição de si próprio como sujeito autônomo, de modo a possibilitar "a reativação permanente de uma atitude, ou seja, um êthos filosófico que seria possível caracterizar como crítica permanente de nosso ser histórico” 33 (Foucault, 2010 c, p. 345). Dito de outra maneira, a atitude crítica viabiliza o sujeito a se servir de seu próprio entendimento a fim de se direcionar para onde melhor lhe convier, facultando-lhe a possibilidade de transformar e de criar.

E transformação remete à mudança de lugar, a deslocamento de pontos de vista, a instauração de novas verdades. Não obstante o conceito de verdade estar geralmente vinculado à noção de perenidade - àquilo que permanece inalterável a

\footnotetext{
${ }^{33}$ Falaremos mais adiante sobre a questão da atitude crítica e da ética dentro da concepção foucaultiana.
} 
quaisquer contingências -, na perspectiva foucaultiana, entretanto, a concepção de verdade é bem distinta: ela é produzida num tempo e num espaço especifico. Foucault traz a possibilidade de uma história crítica da verdade, mostrando o seu distanciamento do vínculo tradicional entre o sujeito de conhecimento e a verdade absoluta, em benefício da articulação entre o sujeito constituído nas práticas sociais e o conceito de verdade como produção. Na história crítica da verdade não há ‘o' sujeito e ‘o' objeto como unidades universais, mas eles assim se tornam mediante práticas, através de jogos (Candiotto, 2006 p. 66).

Convém assinalar as possíveis proximidades entre Foucault e o segundo Wittgenstein, não somente no que dizem respeito à negação da linguagem como representação do real, como também às categorias dos 'jogos de linguagem' enunciados por Wittgenstein, e a dos 'jogos de verdade' problematizados por Foucault. Inicialmente podemos constatar que ambos tratam desses conceitos de maneira bastante semelhante. Wittgenstein constata que "não existe 'a' linguagem, mas simplesmente linguagens, isto é, uma variedade imensa de usos, uma pluralidade de funções ou papéis”. (Condé, 1998 p. 86). Já Foucault parece comungar com as idéias de Wittgenstein, ao afirmar que somos seres de linguagem e não seres que possuem linguagem. Entendemos com isso que para os dois autores, tanto a linguagem como a verdade, é engendrada em um contexto sócio-histórico, e que os seus jogos são, igualmente, convencionados pelo social.

Fato curioso é que, segundo Joel Birman, o conceito de 'jogos de verdade' surgiu a partir do conceito de ‘jogos de linguagem’, o mesmo formulado pelo segundo Wittgenstein nas Investigações Filosóficas.

Parece-nos que, para ambos, afirmar que se trata sempre de um jogo, seja da linguagem seja da verdade, implica sublinhar a presença de uma regra que preside e que seria constitutiva do jogo enquanto tal. [...] A regra seria sempre compartilhada, sendo constituída pela convenção e pelo uso, ambos estabelecidos pelos homens no espaço social. A regra seria então uma produção social, que fundaria igualmente tanto os jogos de linguagem quanto os de verdade, inserindose no registro do artifício e não da natureza. (BIRMAN, 2011, p. 306-307).

Deste modo, pensando-se o sujeito não como um sujeito prévio, definitivo, não como um sujeito do conhecimento - tal qual a visão cartesiana -, mas pensando-o como um processo, considerando-o como uma subjetividade que emerge a cada prática discursiva, Foucault entende o sujeito produzido na 
contingência da história e da cultura. Trata-se, como propõe Benilton Bezerra (2009), de um sujeito constituído e "emergido de um contexto sócio-histórico que lhe aponta uma visão de mundo, que lhe mostra o que existe e o que não existe, o que é certo e o que é errado [...] o sujeito depende de um outro humano que o ensina, através de ações e de palavras, o que é o mundo, o que é ser um sujeito”. Ainda, segundo o autor,

a resposta à pergunta 'o que é ser um sujeito', talvez não seja encontrada na natureza, como se ela lá estivesse posta, definida. Pelo contrário, as formas de ser de um sujeito, a maneira como ele se movimenta no mundo, os modos pelos quais ele se subjetiva, é sempre uma questão a ser refeita a todo o tempo (BEZERRA, 2009).

Para finalizar, talvez pudéssemos ousar propor uma simetria entre a pragmática wittgensteiniana e a genealogia foucaultiana. Assim como o pragmático, o genealogista não procura entender o significado genuíno da coisa ('o que é isso? '), pois se assim o fosse, implicaria em obter, como resposta, uma definição identitária da coisa mesma, ou como nos adverte Condé, ao colocarem questões do tipo ‘o que é o conhecimento?’ ou ‘o que é a loucura?’ ou ‘o que é a linguagem?’, os filósofos apenas estão procurando fantasmas se pretendem encontrar uma essência ou algum tipo de fundamentação ontológica invariável desses conceitos. Na realidade, ao filósofo não cabe fazer perguntas por essências metafísicas do tipo 'o que é...?', mas cabe a ele analisar como e por que são usadas tais conceituações nos diversos contextos linguísticos em que aparecem (Condé, 1998, p. 91).

Do mesmo modo, de acordo com Auterives Maciel, para o genealogista não existe uma essência ou uma verdade à qual ele deve retroagir para encontrar, pois "na origem da coisa não há uma essência, mas tão somente um combate de forças, e é este combate que se encontra na gênese dos valores históricos” (Maciel, 2010).

Assim sendo, pensamos que a verdade só é produzida a partir dos valores que são criados e propostos por um povo. Poderíamos dizer que, assim como Wittgenstein considera os ‘jogos de linguagem’, não como algo provido de uma essência, e sim como uma construção, Foucault também entende a verdade como sendo produzida em uma prática social. O genealogista substitui a questão 
metafísica 'o que é?’, pela questão pragmática ‘a quem interessa isso?’ Para Foucault, todo saber é produzido por um poder que se interessa por determinadas verdades. Suas problematizações se dirigem exatamente ao questionamento a cerca de quais ‘jogos de poder’ possibilitam a emergência de certos saberes (Maciel, 2011).

Quanto a esses jogos, iremos discuti-los a seguir. Vamos, então, a eles.

\subsection{1}

\section{Jogos de Saber, Jogos de Poder e Resistência}

Sabemos da importância em entender a instituição - no sentido proposto por Goffman (1974) -, considerando-se os seus agenciamentos, suas relações de forças e os dispositivos de poder que a constituem. Quando se pensa em poder, é comum associar-se à idéia de violência, de repressão. Por poder, costuma-se entender somente o poder de forma centralizada, como o poder do Estado.

Entretanto, Deleuze (2005) aborda com muita clareza o conceito de poder em Foucault: o poder implica menos em uma propriedade do que em uma estratégia, ou seja, o poder se exerce mais do que se possui. Ele perpassa as formas repressivas, inclusive às ligadas ao aparelho de Estado, e faz aparecer uma teia de micro relações de forças, denominada por Foucault de 'microfísica do poder'. O que faz mover uma sociedade são os inumeráveis pequenos poderes, muito mais do que um poder central (Foucault, 1977 c). Para o autor, não se trata de eliminar o 'por que’ do poder, mas tão somente atribuir uma maior importância à questão de ‘como’ o poder acontece, ou seja, tentar investigar criticamente sobre essa temática, isto é, de como o poder é exercido. Desta forma, abordando-se o tema do poder através de uma análise do 'como', toma-se por objeto de apreciação distintas relações de poder, ao invés do poder entendido como um poder absoluto, globalizante.

Todavia, seria este o tipo de poder produzido nas instituições manicomiais - uma 'microfisica do poder’? Seria possível encontrar aí relações de poder que não fossem relações assimétricas, cristalizadas e bloqueadas - e que, assim, estariam impedindo o sujeito a chance de movimento e de mínima liberdade? Por acaso não estaríamos já, ao tratarmos do denominado 'louco-criminoso', 
presumindo um sujeito em estado de dominação? Se assim o for, como então poderíamos supor a possibilidade de subjetivação do inimputável como sujeito agente, estando ele à mercê do controle do outro e imerso numa total falta de liberdade? Todas estas questões vão surgindo à medida em que buscamos entender melhor quem é esse sujeito e quais os jogos de saber/poder que o constituem.

Mas, afinal, o que é o poder? É o próprio Foucault que nos traz a idéia de que as relações de poder não se passam basicamente ao nível da violência ou da repressão. Seria falso definir o poder como algo que diz não, algo que impõe limite, que exclui e que pune. O poder não apenas castiga, pune ou exclui. Ele produz indivíduos: o individuo é efeito do poder (Machado, 1979).

Assim, em Vigiar e Punir, Foucault traz uma nova concepção de poder, ao divergir da ideia de que o poder seria propriedade de uma classe. Agora ele vê o poder “como uma máquina social que não está situada em um lugar privilegiado ou exclusivo, mas se dissemina por toda a estrutura social. Não é um objeto, uma coisa, mas relação.” (Machado, 1979, p. XIV). O poder funciona como uma rede de dispositivos ou de mecanismos a que ninguém escapa. Precisamente falando, o poder não existe; existem sim, práticas ou relações de poder. Não existem de um lado os que têm o poder e de outro aqueles que se encontram dele alijados. Na realidade, o poder não vem emanado de um determinado ponto ou de um lugar específico; ele é um feixe aberto de relações, de certa forma, organizado (Foucault, 1995 a). O que se faz necessário, na visão do autor, é a análise de como se inscrevem as estratégias de poder e os efeitos que são produzidos por elas. Trata-se de uma rede de micro-relações de forças, de ação sobre ações. O poder designa relações entre sujeitos: é um modo de ação de uns sobre outros. Ele é aqui entendido como um conjunto de ações que se instigam mutuamente.

O poder é um conjunto de ações sobre ações possíveis: ele opera sobre o campo de possibilidade onde se inscreve o comportamento dos sujeitos ativos; ele incita, induz, desvia facilita ou torna mais difícil, amplia ou limita, torna mais ou menos provável; no limite, ele coage ou impede absolutamente, mas é sempre uma maneira de agir sobre um ou vários sujeitos ativos, e o quanto eles agem ou são suscetíveis de agir. Uma ação sobre ações (FOUCAULT, 1995 a, p. 243). 
Não pretendemos, no momento, abordar a questão do poder e da disciplina como produtores dos 'corpos dóceis', nem tampouco problematizar a metamorfose dos métodos punitivos - que passam a dirigir a punição não mais ao corpo, mas, à alma do apenado -, tão brilhantemente exposta por Michel Foucault em Vigiar e Punir, ao afirmar que "à expiação que tripudia sobre o corpo deve suceder um castigo que atue, profundamente, sobre o coração, o intelecto, a vontade, as disposições” (Foucault, 1977 a, p. 20). Faremos alguns comentários sobre essa questão - especificamente no subcapítulo 4.1. - ao refletirmos a respeito da pretensa 'suavização punitiva' que, de fato, nada mais é do que efeito de novas táticas de poder. Do mesmo modo, não nos propomos a discutir o espaço asilar não mais legitimado como espaço de repressão, mas, agora, como espaço normalizador. Temos tão somente, como objetivo, discutir a problemática dos ‘jogos de saber/poder’ no que tange a sua imbricação com os ‘jogos de verdade’ e com as estratégias de resistência.

Retornemos, pois, ao poder. Foucault faz questão de ressaltar que não se trata de confundir ou igualar o poder à repressão, pois,

se o poder tivesse apenas a função de reprimir, se agisse apenas por meio da censura, da exclusão, do impedimento, do recalcamento, à maneira de um grande superego, se apenas se exercesse de um modo negativo, ele seria muito frágil. Se ele é forte, é porque produz efeitos positivos a nível do desejo (FOUCAULT, 1975, p. 148).

E continua:

O problema central do poder não é o da 'servidão voluntária' (como poderíamos desejar ser escravos?): no centro da relação de poder, provocando-a incessantemente, encontra-se a recalcitrância do querer e a intransigência da liberdade. [...] no centro das relações de poder e como condição permanente de sua existência, há uma 'insubmissão' e liberdades essencialmente renitentes (FOUCAULT, 1995 a, p. 244-247).

Observa-se, assim, Michel Foucault sugerindo que toda relação de poder implica em uma estratégia de luta, em uma insubmissão, em uma resistência mesma. Melhor dizendo, só há relação de poder quando há possibilidade de deslocamento, de escape, de fuga. Sendo assim, não se pode afirmar que onde o poder se exerce, a liberdade se esvanece, mas sim, pode-se dizer que, em 
contrapartida, a liberdade - ou seja, a resistência -, aparece como condição de existência do poder (Foucault, 1995).

Desta feita, é correto sustentar que as relações de poder e a resistência não podem ser separadas: faz-se mister analisar as relações de poder através do antagonismo das estratégias de confronto. Estas são, antes de tudo, tipos de lutas contra as formas de dominação, contra a sujeição e as diferentes formas de submissão; a partir destas lutas e da recusa em se aceitar o que lhe foi imposto historicamente, o indivíduo é capaz de promover e de produzir novos modos de subjetivação tentando, não descobrir o que ele é, mas a recusar o que ele é, ou seja, imaginar e construir o que ele poderia vir a ser (Foucault, 1995).

Sem dúvida, podemos observar que o conceito de resistência encontra-se diretamente nodulado em um jogo relacional com o poder, e também ligado ao processo de subjetivação, isto é, aos modos de existência de ser e de agir no mundo: a resistência é um processo de criação, uma possibilidade de transformação. Em outras palavras, poderíamos dizer que, nesse sentido, o poder é produtivo e constitutivo, e vem sempre acompanhado pela força da resistência. Nesse sentido entendemos, pois, a resistência como sendo uma visão crítica em direção às engrenagens do poder, às suas normatizações burocráticas que obstaculizam as práticas libertárias, enfim, como uma perspectiva que visa a desconstruir a lógica institucional, promovendo a possibilidade de novos olhares. Falar em resistência é pensar na produção de novas maneiras de subjetivação, é provocar o surgimento de novas histórias e de novos acontecimentos; é sacudir os antigos paradigmas, desconstruindo o discurso instituído do 'sempre foi assim'...

O grande jogo da história será de quem se apoderar das regras, de quem tomar o lugar daqueles que a utilizam, de quem se disfarçar para pervertê-las, utilizá-las ao inverso e voltá-las contra aqueles que as tinham imposto; de quem, se introduzindo no aparelho complexo, o fizer funcionar de tal modo que os dominadores encontrar-se-ão dominados por suas próprias regras. (MACHADO, 1979, p. 25-26).

Nesse sentido o autor se refere ao poder, acrescentando-lhe uma concepção positiva, como algo libertador, que produz e transforma. Trata-se, por conseguinte, de um conceito de poder como positividade que, deste modo, afasta a concepção negativa que identifica o poder com o Estado e o considera como aquele que reprime, censura e mutila. Ao afirmar que o poder é positivo Foucault 
nos ensina que ele circula, incita e produz efeitos (Fonseca, 2002); produz uma luta de forças onde os sujeitos estão colocados, estrategicamente, dentro de uma rede de relações de poder, de tal forma que, uns resistindo sobre os outros, acabam por fazer com que as relações mesmas de poder se alterem. Percebe-se, assim, como Foucault vai se distanciando da concepção de poder que implicaria em uma negatividade - no sentido de reprimir, restringir ou excluir -, e vai subsumindo a concepção fundada na positividade do poder no que ele significa de incitamento e produção. Nessa acepção, o poder significa luta, afrontamento, disputa, ele faz agir e falar (Foucault, 1977 d). Considerando-o como uma rede de mecanismos, onde se afeta e se é afetado, "sua característica essencial é estar em relação com outras forças; não há, aqui, nem sujeito nem objeto, são puras forças” (Coutinho, 2001, p. 71).

Com efeito, é nesse jogo de forças que o sujeito é constituído. Para Foucault, ele é uma produção da conjunção saber/poder e das estratégias de resistência. Dito de outra maneira: o sujeito, como já mencionado anteriormente, se constitui no interior das práticas, isto é, ele é produto de múltiplas práticas sociais, efeito do saber e do poder. O que está na base do poder, nos ensina Foucault, são os instrumentos de formação e acúmulo de saber. Ao exercer-se, o poder organiza e coloca em circulação um dispositivo de saber, que é ele mesmo, parte do jogo entre resistência e poder. Talvez fosse importante definirmos o que é saber, dentro da visão foucaultiana.

A este conjunto de elementos, formados de maneira regular por uma prática discursiva e que são indispensáveis à constituição de uma ciência, apesar de não se destinarem necessariamente a lhe dar lugar, pode-se chamar saber. [...] Há saberes que são independentes das ciências; mas não há saber sem uma prática discursiva definida, e toda prática discursiva pode definir-se pelo saber que ela forma. (FOUCAULT, 2009 b, p. 204).

Ambos - saber e poder - se implicam mutuamente, sendo impossível estabelecer-se uma relação de poder sem a constituição de um campo de saber, e vice-versa. A análise foucaultiana sustenta que saber e poder encontram-se, intrinsecamente, nodulados.

Não há relação de poder sem constituição de um campo de saber, como também, reciprocamente, todo saber constitui novas relações de poder. Todo ponto de 
exercício do poder é, ao mesmo tempo, um lugar de formação de saber. [...] todo saber assegura o exercício de um poder (MACHADO, 1979, p. XXI-XXII).

Esta imbricação entre a formação de saber e o exercício do poder é facilmente observável na execução dos laudos e pareceres elaborados pelos profissionais 'psi' que operam no campo do instituído: o poder cria matéria de saber que, por si, produz efeitos de poder. Sobre estes dispositivos de saber/poder iremos problematizar mais adiante, no subcapítulo 3.3.

Mas falávamos da positividade do poder: um poder que produz indivíduos, que incita, que age sobre o sujeito, provocando ação, resistência. Podemos constatar esse fato no campo mesmo do MJ, quando vemos o paciente resistindo às determinações e injunções que lhe são impostas. O mesmo se percebe não só no paciente, como também em alguns poucos combatentes da área 'psi'. Contudo, não se pode negar que, em várias situações, vê-se, de fato, o poder sendo exercido em sua negatividade, expressando-se de forma repressora e excludente. Façamos uma pausa para três histórias 'manicomiais':

Certa feita, por motivo da comemoração dos aniversariantes do mês, algumas pacientes do $\mathrm{SIF}^{34}$ solicitaram ir à festa com trajes comuns, ao invés de uniformizadas. A título de informação, todos os pacientes do MJ, especialmente as mulheres, eram obrigados a vestir o uniforme da instituição, independentemente da ocasião que fosse. Apesar da insistência das pacientes femininas, o pedido lhes foi negado. Venceu a lei do mais forte: as pacientes que quisessem participar da festa teriam que ir uniformizadas. Algumas não foram...

Em outra ocasião, a despeito de ‘cuidar da integridade física' dos pacientes, a direção e o setor de segurança da instituição mantiveram-nos trancados por meses no interior das enfermarias, impedindo-os inclusive de ter acesso às suas equipes. Nesta época, usou-se como argumento a disputa de território entre as favelas no entorno do bairro do Estácio. Dizia-se que era necessário mantê-los encarcerados, protegendo-os dos 'perigos externos aos muros da instituição' - como se, de fato, houvesse algum perigo -, isolando-os do contato de todos. O MJ parecia uma terra abandonada, inabitada. Ninguém caminhava pelos pátios, não se ouvia nenhuma voz, a não ser - ao longe -, os murmúrios delirantes de alguns. A despeito de todas as solicitações que fizemos à

\footnotetext{
${ }^{34}$ Setor de Internação Feminina.
} 
Direção, os pacientes foram mantidos trancados. Vê-se, aí, o poder se exercendo, não somente sobre a massa carcerária, como igualmente sobre os profissionais, a maioria, diga-se de passagem, concordante com a decisão da direção pela manutenção do isolamento. De todo modo, continuamos a insistir ...

Um dos momentos mais marcantes e mobilizantes durante o trabalho no MJ deu-se por ocasião de uma discussão travada com o diretor a respeito da Lei de Execução Penal, onde consta um artigo no qual o paciente é autorizado a solicitar, ele próprio, a sua desinternação. ${ }^{35}$ Não obstante esse direito constasse na letra da lei, a solicitação dos pacientes era via de regra, negada pela direção da instituição. Caso o paciente se mostrasse insistente em seu pedido, não raro, a equipe técnica o diagnosticava como ‘descompensado’ ou ‘insubordinado’, o que resultava, na maior parte das vezes, a sua punição na 'tranca' por alguns dias. Nem por isso desistíamos dos nossos embates travados com os mais fortes...

Mas isso é uma outra história a ser tratada no Capítulo 4.

Para finalizar, gostaríamos de reafirmar a idéia de Foucault quanto à sustentação de que o saber - assim como o poder -, não é algo estático, mas manifestado a partir de contingências, encontrando-se, ambos, em constante e infindável imbricação. Trata-se de uma relação onde, saber, poder e resistência produzem-se e engendram-se mutuamente. E é nessa trama de relações que as verdades são produzidas - ou inventadas!

\section{2 .2}

\section{Jogos de Verdade: 'Porque sempre foi assim'...}

Como falávamos anteriormente, saber e poder encontram-se vigorosamente associados, e a verdade é uma função no interior de seu jogo: “a verdade está circularmente ligada a sistemas de poder, que a produzem e apoiam, e a efeitos de poder que ela induz e que a reproduzem.” (Foucault, 1979 a, p.14). Não existe formação de saber sem um exercício de poder que o sustente, assim

\footnotetext{
${ }^{35}$ A Lei de Execução Penal no 7.210, de 11 de Julho de 1984, institui em seu Art.176 que: "em qualquer tempo, ainda no decorrer do prazo mínimo de duração da medida de segurança, poderá o Juiz da execução, diante de requerimento fundamentado do Ministério Público ou do interessado, seu procurador ou defensor, ordenar o exame para que se verifique a cessação da periculosidade, procedendo-se nos termos do artigo anterior”.
} 
como não há exercício de poder sem a circulação de uma verdade (Fonseca, 2002). Dito de outra maneira, as relações de saber/poder produzem, por assim dizer, verdades que, no entendimento de Foucault, nada mais seriam do que "o conjunto de procedimentos que permitem a cada instante e a cada um pronunciar enunciados que serão considerados verdadeiros” (Foucault, 1977 c, p. 233).

Contudo, completa o autor, a verdade não é uma instância suprema. Segundo a sua concepção, o óbvio e o evidente são efeitos de jogos de saber/poder que tornam certas verdades, universais e absolutas. Admitindo que a verdade não aparece ajustada a nenhuma referência - isto é, ela não corresponde, necessariamente, a seu objeto -, faz Foucault pensar que a verdade em si não existe. Em outras palavras, dado que os fatos humanos não se moldam sobre uma referência, mas, sim, eles são produzidos na contingência da história, então, todo acontecimento histórico é singular e, sendo assim, não existem verdades gerais nem absolutas.

O pensamento de Foucault transgride a ideia de uma 'ilusão tranquilizadora' (Veyne, 2004) que nos faz perceber os fatos humanos através das generalidades, das naturalizações. Seu trabalho arqueogenealógico se encarrega de descobrir - no sentido de desvendar -, o que está escondido, dissimulado sob essas generalidades ou, como reflete Veyne, sob as 'generalidades enganosas', mas não no sentido de descobrir o desenvolvimento de suas origens, sua transcendentalidade, mas, muito pelo contrário, de demonstrar que a verdade é histórica, fortuita e contingente. A uma origem transcendental do pensamento, Foucault opõe uma origem empírica e contextualizada.

Assim, o autor enuncia que a verdade está inserida em 'jogos de verdade’, entendidos como regras compartilhadas, constituídas por uma convenção e pelo uso em determinado contexto, algo que regularia o modo de produção dos discursos (Foucault, 1984 a). O que significaria dizer que as verdades atribuídas aos sujeitos são, em última instância, efeitos de verdade produzidos por mecanismos estratégicos de poder que imputam ao sujeito determinadas normas, classificando-os, sujeitando-os e adestrando-os. Os ‘jogos de verdade’, produzidos por jogos de poder, transitam como postulados instituídos, inflexíveis, imutáveis e principalmente, inquestionáveis no interior das instituições totais: eles são um conjunto de regras de produção de verdade. Muitas vezes, tanto na instituição 
prisional quanto na instituição psiquiátrica, faz-se clara a observação de 'jogos de verdade' como efeito de jogos de poder, relativos a certos interesses que determinam algumas premissas como verdadeiras, e outras, como falsas.

Tomemos como exemplo o caso dos nossos pacientes inimputáveis, já apresentados no capítulo anterior.

A partir de um laudo que comprova a sua condição de inimputabilidade, o paciente é encarcerado sem data prevista para a sua desinternação. A cada período de anos que, a rigor, deveria ser uma vez ao ano, o sujeito é submetido a novos exames - os chamados 'laudos de cessação de periculosidade'36 - que pretendem aferir a sua 'capacidade para voltar ao convívio social', ainda que seja somente nos fins de semana. Dentro deste contexto, é comum observar-se a prorrogação do período de internação por tempo demasiadamente longo, período este, determinado e fixado pelo próprio poder médico, delegado ao psiquiatra, justificando-se, assim, as decisões tomadas por ele: “o poder que o hospício dá ao psiquiatra, deverá, portanto, se justificar, produzindo fenômenos integráveis à ciência médica” (Foucault, 1997, p. 50).

Toda esta engrenagem é amparada por jogos de saber/poder produzidos por uma discutível cientificidade, que pretendem provar a existência incrustada de um estado de 'periculosidade' - discutido anteriormente - no paciente inimputável, julgando-o perigoso sob qualquer circunstância, e destinando-o a ser, para sempre, aquele sujeito delituoso e louco ao tempo da ação. Trata-se de um 'jogo de verdade’ - claramente estabelecido -, efeito de um 'jogo de saber/poder’ que pressupõe o que é normal e o que é patológico. Estas e outras crenças institucionalizadas, apoiadas em amarras do direito, e porque não dizer, da psicologia positivista, vão perpassando por entre os vários tempos da psiquiatria, criando-se ‘jogos de verdade’ inquestionáveis e indiscutíveis. Assim, de acordo com a reflexão foucaultiana, "vivemos em uma sociedade que em grande parte marcha 'ao compasso da verdade', ou seja, produz e faz circular discursos que funcionam como verdade, que passam por tal e que detêm por este motivo poderes específicos” (Foucault, 1979 b, p. 231). Para o autor, estes ‘jogos de verdade’ são tão somente efeito de ‘jogos de poder’. Não raro se ouve, com frequência, uma

\footnotetext{
${ }^{36}$ Como vimos no Capítulo 2, a periculosidade do paciente inimputável é avaliada a partir da elaboração dos referidos laudos, realizados por peritos forense, lotados no Setor de Perícias do MJ.
} 
expressão dita pelos profissionais 'psi' e demais funcionários do MJ quando questionados sobre o porquê de uma determinada regra instituída; a resposta é sempre seca e simples: 'porque sempre foi assim'...

Fabricadas nos interstícios dos jogos de poder, as verdades ditas no interior de qualquer nosocômio geram, não somente crenças e regras dentro do campo mesmo do instituído, como também produzem sujeitos, impelindo-os a modos de subjetivação normatizadores. Não seria exagerado afirmar-se, embasando-nos nas lições de Foucault, que os 'jogos de verdade’ produzem, distribuem e fazem circular enunciados aos quais se atribui efeitos de poder: o poder de serem aceitos como verdadeiros (Bruni, 1989). Isto ocorre porque aquele que tem a possibilidade de formular verdades, também tem o poder de dizê-las e de expressá-las como quiser. Em entrevista concedida em 1978, Foucault tece alguns comentários a respeito do tema sobre a força de quem pronuncia a verdade, especialmente quando ela é proferida pelo campo do judiciário:

[...] É preciso que o indivíduo seja condenável e condenado. Pouco importa a natureza das provas sobre a base das quais se o condena, pois, nós bem o sabemos, o essencial em uma condenação não reside na qualidade das provas, mas na força daquele que a pronuncia (FOUCAULT, 1978 c, p. 273. Grifo nosso).

Com efeito, é a partir de práticas de poder e de certos jogos de verdade, que o sujeito é constituído: louco, sem razão, doente ou normal, dependendo de quem assim o denomina. Por conseguinte, os ‘jogos de verdade’, que são efeitos de ‘jogos de poder’ passam a ser uma das práticas mais visíveis empregada no interior do MJ. Observa-se que, através da aplicação de alguns dispositivos legais utilizados pelo direito e pela psicologia na aferição e na classificação dos sujeitos internados, exerce-se um poder como forma geral de saber, produzindo-se efeitos de verdade. O jurista Salo de Carvalho nos aponta para certas técnicas psicológicas que se colocam como discursos de verdade no processo de execução, reeditando um sistema típico dos sistemas inquisitivos pré-modernos, que unem a psicologia e o direito:

Não obstante a legitimação de um modelo moralista fundado na recuperação, o discurso clínico-disciplinar, ao atuar como suporte ao jurídico e, assim sendo, fundir-se a ele nas decisões em sede executiva, cria um terceiro discurso, nãojurídico e não-psiquiátrico, autoproclamado criminológico, que, apesar da 
absoluta carência epistemológica, é altamente funcional (CARVALHO, 2008, p.201).

Para Foucault, este processo é resultado do encontro entre o saber médico e o poder judiciário, e esses dispositivos têm o seu modelo espelhado nos antigos exames da Inquisição.

O inquérito é precisamente uma forma política, uma forma de gestão, de exercício do poder que, por meio da instituição judiciária, veio a ser uma maneira, na cultura ocidental, de autentificar a verdade, de adquirir coisas que vão ser consideradas como verdadeiras e de as transmitir. O inquérito é uma forma de saber-poder (FOUCAULT, 2005, p.78).

Sobre eles, iremos tratar no subcapítulo seguinte, dando uma maior ênfase - dentre os laudos e exames utilizados no campo jurídico-psiquiátrico - ao ‘Exame Criminológico’ que, no caso, só é aplicável aos presos comuns: aqueles condenados que cumprem pena nas penitenciárias. Este tipo de exame pretende aferir a 'previsibilidade de comportamento' futuro do apenado, determinando se ele voltará ou não a delinquir. A elaboração deste exame obedece a um determinismo causal, onde o técnico não só deverá descrever a história do apenado, como também deverá prever a sua conduta futura. Os riscos desta estranha cena levam, muitas vezes, a se observar pareceres preconceituosos que repetem os próprios julgamentos pré-concebidos que a sociedade tem do condenado (Ibrahim, 1999). Em Criminologia e Subjetividade no Brasil, Cristina Rauter destaca este aspecto determinista observado em alguns exames que descrevem o apenado:

Totalmente abandonado pelos familiares, aos 15 anos inicia-se na prostituição. [...] mantém uma conduta uniforme desde a infância, mostrando-se pessoa de fácil sugestionabilidade com tendências à delinquência (RAUTER, 2003, p. 107).

Em suma, ele fica marcado, definitivamente, pelo crime que cometeu. Contudo, esta marca não é mais forte do que a probabilidade de que ele venha a cometê-lo novamente, segundo a crença de alguns juristas, de alguns profissionais da área 'psi’, e da sociedade mesma. É o que Foucault denomina de 'virtualidade’, matéria já apresentada anteriormente neste trabalho. 
Deste modo, portanto, se manifestam os 'jogos de saber/poder' e os 'jogos de verdade' no campo do instituído: através de dispositivos legais que reorganizam e enfatizam o funcionamento do poder, que se expressam sob formas tecnicizadas, inventadas para moldar e orientar a conduta de sujeitos nas direções desejadas, numa tentativa de instalar um modelo único de subjetividade ‘apropriada'. São os procedimentos técnicos, travestidos de cientificidade, incluindo-se aí os exames psicológicos, os laudos, as perícias e tantos outros modos de aferição e avaliação do sujeito que, segundo a ótica foucaultiana, são maneiras não só do saber/poder se exercer, como também uma forma de se produzir verdades. Propondo-se a investigar o campo em que essas verdades se constituem, o interesse de Foucault sempre foi o de analisar em que condições elas são produzidas e a que objetivos elas estão articuladas.

Para terminar, trazemos Paul Veyne, que usa uma imagem bastante criativa e interessante ao refletir sobre a verdade, dentro da visão foucaultiana. Segundo ele, assim como não se pode saber o que é, na realidade 'o' poder ou 'a' loucura e a tantas outras matérias, não poderia haver verdade ou erro no que concerne a elas, dado que não existem. E reafirma que "a cada momento, este mundo é o que é [...] as figuras futuras do caleidoscópio não são nem mais verdadeiras nem mais falsas do que as precedentes” (Veyne, 1990, p. 274). Essa imagem nos parece perfeita para tentarmos entender a questão da verdade e seu caráter fortuito e contingente, em constante transformação, construída e reconstruída a cada momento de formas distintas, tal qual a imagem do caleidoscópio.

\section{3}

\section{O campo do instituído: dispositivos e especialistas}

\subsection{1}

\section{Os reis-ubus e a rede maquiada de cientificidade.}

Pensamos inicialmente em apresentar uma subdivisão nesse capítulo, com o objetivo de problematizar, diferencialmente, a questão dos especialistas (os 'reis-ubus') e dos dispositivos (uma rede maquiada de cientificidade) por eles 
utilizados no campo do instituído. Contudo, ao longo da produção do capítulo, sentimos dificuldade em tratar separadamente esses dois temas, pois, com efeito, eles se encontram tão naturalmente imbricados, demonstrando, assim, o quanto especialistas e dispositivos são parte de um mesmo sistema.

Ao ler Foucault torna-se quase impossível não se fazer uma associação de seus pensamentos aos acontecimentos da atualidade. Assim, ao problematizar os caminhos da história, Foucault nos faz refletir sobre os descaminhos das práticas 'psi’, em especial sobre alguns dispositivos jurídico-psiquiátricos utilizados, na maior parte das vezes, de forma indiscriminada nos campos da psiquiatria, da psicologia e do direito penal.

Trazendo como exemplo os laudos psiquiátricos e os exames psicológicos fartamente utilizados nas redes institucionais de um modo geral, não é difícil perceber como a preocupação com a busca da verdade norteia esses diversos procedimentos judiciais. Neles, tenta-se reconstruir a história do sujeito, tão somente com uma única preocupação: a busca da verdade absoluta.

Nos procedimentos judiciais e policiais [...] um objetivo claro deve ser alcançado e é ele que norteia os interrogatórios, os inquéritos, a fala das testemunhas: a reconstituição do passado "tal como ele ocorreu". A partir de fatos concretos vistos por alguém, a partir da fala do acusado, fonte de erros e falseamentos e que deve ser deles depurada, buscar-se-ia chegar à "verdade”. (RAUTER, 2003, p. 89).

A posição de Foucault é justamente oposta a esta, e Veyne (1990) nos mostra, logo ao início de seu artigo, Foucault revoluciona a história, que a intuição foucaultiana inicial não é a estrutura, mas a raridade. O que é, poderia ser diferente. Para Foucault, os fatos humanos são raros, não estão instalados na plenitude da razão. Eles são arbitrários, não são óbvios. Tanto Veyne quanto Foucault, assim também como Nietzsche, todos eles enfatizam a importância da história/genealogia que é marcada - como vimos previamente -, por acasos e contingências, e não simplesmente por seu aspecto factual.

Não raro encontram-se laudos e exames onde é enfatizada a história pregressa do apenado ou do paciente, tentando buscar no passado, verdades que confirmem o presente. Desta forma, "a elaboração dos exames obedecem a um determinismo causal, onde o 'nosólogo' não só descreve a doença/delito do paciente/preso, mas também prescreve a sua conduta futura” (Ibrahim, 1995, p. 
52). Ou seja, o saber 'psi' parece crer em uma essência da loucura e que esta pode ser dita por ele, sujeito 'psi'. Dito de outra maneira, o saber 'psi' acredita que pode revelar o que está na origem da loucura, assim como se preocupava a metafísica com a origem da coisa. Na perspectiva genealógica não há coisa, mas forças, cujo sentido é a relação. E relação é, sem sombra de dúvida, o que não ocorre durante uma situação de exame de avaliação no interior dos campos de saber da psiquiatria e da psicologia.

Tomemos como análise o já citado 'Exame Criminológico', um dos dispositivos de controle amplamente utilizado no sistema prisional do Rio de Janeiro, aplicado àqueles que estão em vias de obter o livramento condicional ${ }^{37}$. Antes, porém, apresentamos uma definição do que seja o exame, segundo Foucault:

O exame combina as técnicas da hierarquia que vigia e as da sanção que normaliza. È um controle normatizante, uma vigilância que permite qualificar, classificar e punir. Estabelece sobre os indivíduos uma visibilidade através da qual eles são diferenciados e sancionados. [...] Nele vêm-se reunir a cerimônia do poder e a forma da experiência, a demonstração da força e o estabelecimento da verdade. [...] A superposição das relações de poder e das de saber assume no exame todo o seu brilho visível (FOUCAULT, 1977 a, p. 164-165. Grifo nosso).

O exame, na concepção foucaultiana, supõe um mecanismo “que liga um certo tipo de formação de saber a uma certa forma de exercício de poder” (Foucault, 1977 a, p. 166). Dentro deste contexto, é possível observar-se práticas semelhantes ao exame propriamente dito, que documentam e arquivam com detalhes o dia-a-dia do detento ou do paciente. Essas práticas localizam os indivíduos num campo de vigilância não só através de um controle panóptico, como também da regulamentação e da fiscalização a partir do que Foucault denomina de 'poder de escrita', isto é, procedimentos de exame adicionados de um sistema de registro intenso e de farto material documental. Reportemo-nos, mais uma vez, ao 'Exame Criminológico': ao elaborar esse tipo de exame, o especialista é munido - nos parece o vocábulo mais apropriado para definir a situação - do registro de ‘transcrição da folha disciplinar' do referido detento. Isto significa dizer que, ao receber aquele indivíduo pela primeira e única vez, o

\footnotetext{
${ }^{37}$ Trata-se da concessão da liberdade antecipada do réu, mediante o cumprimento de certos requisitos legais.
} 
profissional 'psi' deverá basear-se, não somente na realização mesma do exame, mas também, respaldar-se nas informações sobre a sua conduta disciplinar dentro do cárcere. Não nos esqueçamos de que é o setor de guardas de segurança quem elabora a ficha de comportamento do apenado... Assim sendo, constata-se que tal prática esteja, efetivamente, comprometida com todo um campo de saber e todo um tipo de poder. Elaborado com base no Art. 83 do Código Penal, o 'Exame Criminológico’ deve ser apreciado pelo Conselho Penitenciário e pela Vara de Execuções Penais (VEP) que esperam, seja ele, esclarecedor da 'previsibilidade de comportamento futuro' do condenado. Eis o Artigo:

Art. 83 - O juiz poderá conceder livramento condicional ao condenado a pena privativa de condicional liberdade igual ou superior a dois anos, desde que [...]: Parágrafo único - Para o condenado por crime doloso, cometido com violência ou grave ameaça à pessoa, a concessão do livramento ficará também subordinada à constatação de condições pessoais que façam presumir que o liberado não voltará a delinquir. (Lei 7209 de 11 de julho de 1984. Grifo nosso) ${ }^{38}$.

Tendo em vista o previsto na lei, conclui-se que este tipo de exame, mais absurdamente ainda, propõe avaliar a previsibilidade de comportamento do apenado, ao nível de suas virtualidades, termo já discutido na última parte do Capítulo 2. A partir de um único encontro entre ele e o 'especialista', é necessário que fique esclarecido às instâncias jurídicas, o grau de previsibilidade de seu comportamento, confirmando-se se aquele sujeito ‘voltará ou não a delinquir', isto é, se aquele sujeito ‘ainda é perigoso'. Desta forma, o profissional 'psi' passa a funcionar como mecanismo e instância de defesa social e aparece aqui como a figura, cunhada por Foucault, do 'médico-juiz' que, ao descrever o caráter de delinquência e as suas 'condutas criminosas desde a infância', contribui para deslocar o sujeito “da condição de réu ao estatuto de condenado” (Foucault, 2001, p. 27). Isto significa dizer que, mais do que punir as suas infrações, tem-se como função agora, corrigir as suas virtualidades.

\footnotetext{
${ }^{38} \mathrm{O}$ jurista Salo de Carvalho aponta para o fato de que, em nossos dias, o juiz já não julga mais sozinho: "Ao longo do processo penal, e da execução da pena, prolifera toda uma série de instâncias anexas. Pequenas justiças e juízes paralelos se multiplicam em torno do julgamento principal: peritos psiquiátricos e psicólogos, magistrados da aplicação da pena, educadores, funcionários da administração penitenciária fracionam o poder legal de punir” (Carvalho, 2008, p. 187-188).
} 
Ao colocar cada vez mais no primeiro plano não apenas o criminoso como sujeito do ato, mas também o indivíduo perigoso como virtualidade de atos, será que não se dão à sociedade direitos sobre o indivíduo a partir do que ele é? Não mais, é claro, a partir do que ele é por status (como era o caso nas sociedades do Antigo Regime), mas do que ele é por natureza, segundo a sua constituição, seus traços de caráter ou suas variáveis patológicas (FOUCAULT, 1978 a, p.24).

Assim, pune-se o condenado duplamente: já não bastasse a punição sobre o seu crime mesmo, pune-se o próprio criminoso, incidindo sobre seus motivos, suas tendências, seus instintos: “doravante se procura adaptar as modalidades da punição à natureza do criminoso” (Foucault, 1978 a, p. 12).

A aferição do citado grau de previsibilidade de comportamento futuro é delegada a um agente de saber: o perito, o especialista, detentor de todo o saber sobre o sujeito. O preso, geralmente angustiado com a situação do exame, vê-se diante de um agente 'psi', que lhe é totalmente desconhecido, estabelecendo-se, de imediato, uma relação de saber/poder. De um lado o nosólogo, que detém o saber a respeito da 'interioridade' daquele indivíduo e de como ela se expressa e que, a partir de determinadas premissas instituídas cientificamente como verdadeiras, exerce o poder de decidir sobre a sua vida futura. Do outro lado está o 'apenado' desprovido, naquele momento, de qualquer saber/poder, e de quem se espera uma atitude passiva e subserviente, só lhe restando aguardar pela sua sentença. É por esse motivo que Thomas Szasz (1980) considera que os métodos de exame retiram do paciente o poder de consentir, colocando-o nas mãos da autoridade médica-jurídica.

Tais dispositivos jurídico-psiquiátricos são focos de produção de sujeitos submetidos às práticas de saber e às relações de poder. Isto significa dizer que estes dispositivos podem ser vistos como um conjunto de práticas normativas de saber e de práticas coercitivas de poder, melhor dizendo, um conjunto de regras de produção de verdade (Foucault, 2005). Tal regime de verdades se sustenta, principalmente pelo fato de ser considerado legítimo, tanto pela psiquiatria quanto pelo direito, justificando-se, assim, as formas de dominação do sujeito encarcerado. Com efeito, podemos subsumir que tais práticas produzem sujeitos.

Acrescido a tudo isso, pode-se observar no conteúdo desses pareceres, um forte componente preconceituoso que tenta confirmar acontecimentos na vida daquele sujeito que, por sua própria natureza, são considerados geradores de crime - miséria, desagregação da família, adição a drogas, e outros. Não lhe resta mais 
nada a não ser cumprir o seu destino de criminoso. Da mesma forma, a natureza do delito pode ser fonte de interpretações preconceituosas, condenando-se o apenado duas vezes através da simples revisão do processo, dando-se importância ao fato, e não ao homem. Apesar de previamente julgado e condenado, tanto o direito quanto a psicologia o colocam novamente no banco dos réus.

Concluída esta etapa, o exame percorre um longo caminho, passando por diversas instâncias judiciárias, chegando finalmente à Vara de Execuções Penais, onde é decidido o destino final do apenado. Não é difícil se perceber o quanto o 'Exame Criminológico’ é mais um instrumento de controle da vida do sujeito, um instrumento técnico travestido de uma roupagem cientifica, disfarçando atitudes e crenças preconceituosas e perversas. Como diz Foucault, os laudos e exames têm como função oferecer aos mecanismos e instâncias punitivas, tão somente uma justificativa legal, não apenas para condenar o individuo pelas infrações cometidas, mas também por aquilo que ele é ou por aquilo que ele virá a ser (Foucault, 2005).

Mas voltemos à esdrúxula situação de exame entre condenado e especialista, à qual Foucault utiliza o caráter grotesco, ubuesco ${ }^{39}$ do discurso penal:

\begin{abstract}
Chamarei de "grotesco" o fato, para um discurso ou para um indivíduo, de deter por estatuto efeitos de poder de que sua qualidade intrínseca deveria privá-los. O grotesco ou, se quiserem, o "ubuesco" não é simplesmente uma categoria de injúrias [...]. O terror ubuesco, a soberania grotesca ou, em termos mais austeros, a maximização dos efeitos do poder a partir da desqualificação de quem os produz: isso, creio eu, não é um acidente na história do poder, não é uma falha mecânica. Parece-me que é uma das engrenagens que são parte inerente dos mecanismos de poder (FOUCAULT, 2001, p. 15).
\end{abstract}

O perito psiquiátrico seria, nesse sentido, o próprio personagem Ubu: ele só pode exercer o terrível poder que lhe pedem para exercer (Foucault, 2001). Ao longo dos séculos o poder de julgar foi, em parte, transferido a instâncias que não as dos juízes de condenação: ‘juízes paralelos’ surgiram de instâncias anexas que se ocuparam em escusar o juiz mesmo da função de punir (Foucault, 1977 a). Agora, é o profissional 'psi' que o faz. É ele quem detém o saber sobre a verdade

${ }^{39}$ O adjetivo 'ubuesco' foi introduzido em 1922, a partir da peça Ubu roi de A. Jarry. Este personagem é qualificado por um caráter cínico, comicamente cruel e covarde ao extremo. $\mathrm{Na}$ concepção foucaultiana, o 'terror ubuesco' é o exercício do poder através da desqualificação explícita de quem o exerce. 
do paciente, é ele - esse pseudo-juiz modulador da pena (Foucault, 1974) - quem exerce o poder para mantê-lo encarcerado e, finalmente, é ele quem programa a sua vida futura dentro da instituição, produzindo verdades. Contudo, não é apenas através da execução de laudos e pareceres que ele exerce seu poder, mas também - e principalmente -, através de outras práticas de controle e de normatização. No Capítulo 3 iremos refletir com maior ênfase o papel do profissional 'psi' e as possíveis formas de resistência àquilo que aparece como inquestionável no interior do campo do instituído.

Vimos que o dispositivo do exame é um tipo de estratégia para manejar os jogos de força numa determinada direção: ele é uma espécie de tecnologia que visa extrair do indivíduo um saber para, então, dar a ele uma forma (Maciel, 2011). Assim como o inquérito, ele é um procedimento jurídico de obtenção da verdade, que aparece travestido de cientificidade a partir do século XVII. Trata-se de uma tecnologia de poder que consiste em produzir verdades. Por conseguinte, os dispositivos psico-jurídicos ${ }^{40}$, grosso modo, gozam de certa regalia, pois “comportam presunções estatutárias de verdade e de poder que lhe são inerentes, em função dos que as enunciam. [...] são uma espécie de supralegalidade de enunciados na produção da verdade judiciária” (Foucault, 2001, p. 14).

Segundo Foucault, estes discursos presentes nos laudos do século XIX imbricados no cruzamento da instituição jurídica e do saber médico -, têm um caráter muito particular. Em primeiro lugar porque eles têm o poder de estabelecer uma decisão judicial com respeito à liberdade ou à detenção de um homem. Ao mesmo tempo são discursos que detém tal poder por, justamente, apresentarem-se como discursos de verdade, por serem discursos dotados de um estatuto científico e formulados - de modo exclusivo -, por pessoas qualificadas para dizê-los (Fonseca, 2002, p. 74). Estes laudos apontam, com veemência, as condutas anormais e irregulares como origem e causa única do crime legitimando, assim, o poder de punir não exatamente a infração, mas o corpo mesmo do indivíduo. O que será julgado pela instância jurídico-psiquiátrica não será o delito cometido, mas tão somente as condutas irregulares consideradas agora como causa e lugar de formação do crime. O objetivo de tais dispositivos seria o de

\footnotetext{
${ }^{40}$ Dentre os diversos dispositivos do gênero, citamos - para efeitos de exemplificação -, os laudos de cessação de periculosidade, os de sanidade mental e os exames criminológicos.
} 
reconstituir a série do que poderíamos chamar de faltas sem infração, ou também de defeitos sem ilegalidade. Em outras palavras, mostrar como o indivíduo já se parecia com seu crime antes de o ter cometido. [...] O que é mais grave é que, na verdade, o que é proposto nesse momento pela psiquiatria não é a explicação do crime: na realidade, o que se tem de punir é a própria coisa, e é sobre ela que o aparelho judiciário tem de se abater (FOUCAULT, 2001, p. 21-24. Grifo nosso).

Não nos enganemos com o fato desses discursos terem sido apenas práticas utilizadas há um século atrás. Em pleno século $\mathrm{XX}$ a psiquiatria continuava a responder ao aparelho judiciário dentro das mesmas descrições ubuescas, onde se buscavam os aspectos da hereditariedade e da ascendência, tentando se chegar à essência do indivíduo comprovando, assim, o seu caráter perigoso.

Tipo criminale com fisionomia meno feroce, ma più repellente di quella del caso precedente. È um tipo di delinqüente-nato, ma anche di pazzo e, specialmente, di delirante cronico a nota sanguinaria persecutrice. Questo soggetto, impazzito in carcere, è forse sempre stato un paranoide per costituzione e, secondo noi, realizza assieme al caso precedente la fusione del tipo criminale col pazzesco. $\mathrm{Da}$ questa fusione scaturisce forse il tipo criminale più completo, meglio di quello che è legato soltanto alla primitività atavica (MANDALARI, 1901, p. $95)^{41}$.

Assim como o 'Exame Criminológico’ - este na esfera criminal - existe outra forma de nosologização e de classificação, agora do indivíduo encarcerado em manicômio judiciário. Trata-se - no caso do paciente inimputável -, do ‘laudo de sanidade mental', realizado por perito forense. Este tipo de exame é solicitado pelas instâncias judiciárias ${ }^{42}$ a fim de assessorá-las tecnicamente no que diz respeito à aferição de sanidade mental do indivíduo que está sendo julgado. Neste caso, o perito forense elabora o laudo com o intuito de avaliar se o réu é ou não considerado inimputável. Deste modo, orientado pela psiquiatria, o direito penal confirma que - aferido o estado de inimputabilidade -, o doente mental não pode

\footnotetext{
41 "Individuo criminoso com fisionomia menos feroz, entretanto mais repelente do que o caso anterior. É um delinqüente-nato, mas também louco e, especialmente delirante crônico com sinal de perseguição sanguinária. Este doente mental encarcerado sempre foi um paranoide por constituição e, em nossa opinião, trata-se de um caso semelhante ao precedente, de fusão de crime e loucura. Desta fusão origina-se, talvez, o tipo criminal mais completo, melhor do aquele que é herdeiro exclusivo do primitivo atávico" (Tradução nossa).
}

${ }^{42}$ Estamos nos referindo à Defensoria Pública, ao Ministério Público e à Vara de Execuções Penais. 
ser punido por culpabilidade. Conclui Brito e Souto (2007) que, enquanto no imputável a culpa produz censura, no caso do inimputável a reprovação penal passa a ser justificada pelo perigo que tal indivíduo representa para a sociedade.

Como vimos na parte final do Capítulo 2, as medidas de segurança se fundamentam na presunção de periculosidade ${ }^{43}$, conceito duramente criticado por Eugenio Zaffaroni como uma das pretensões mais ambiciosas da criminologia ao aspirar medir a periculosidade de qualquer que seja o indivíduo (Zaffaroni, 1993). O ‘periculosômetro', ironicamente usado pelo autor, pretende estudar, classificar e quantificar o sujeito, além de prescrever seu futuro. Do outro lado do mundo, há algumas décadas atrás, Michel Foucault - exatamente a respeito dos reveses da criminologia - comentava em uma de suas inúmeras entrevistas que os textos dos criminologistas "não têm pé nem cabeça [...] Tem-se a impressão que o discurso da criminologia não tem necessidade de ter uma coerência ou estrutura. Ele é inteiramente utilitário” (Foucault, 1979 c, p. 138). Isto posto, parece que o filósofo indicava que a utilidade de tais exames era a de viabilizar argumentos ao julgamento, isentando os magistrados de sua responsabilidade pelo ato. Observase, assim, que o 'exame de verificação de cessação de periculosidade’ mostra-se como um dos dispositivos mais cruéis e perversos da seara criminológica, oportunizando e facilitando a criminalização da doença. Dito de outra forma, a aplicação de tal dispositivo faz constatar que o sujeito delinquente é portador de doença mental, donde se conclui que a doença torna o sujeito perigoso e, em contrapartida, por trás do crime, há perigo de loucura. Com efeito, ao tratar o conteúdo da periculosidade como diagnóstico, assume-se a conotação normativa e estigmatizante do discurso da criminologia positivista. Ainda, segundo Brito e Souto (2007), nada há neles de conteúdo científico, mas tão somente "uma futurologia perigosista de controle social”, fazendo com que o inimputável seja visto como uma ameaça à sociedade, dada a probabilidade de cometimento de

\footnotetext{
${ }^{43}$ O Art. 171 da Lei de Execução Penal de 1984 - vigente até os dias atuais -, determina que "reconhecida a inimputabilidade do réu, nos termos do art.26, caput, do CP, inadmite-se a substituição da medida de segurança de internação em hospital de custódia e tratamento psiquiátrico por tratamento ambulatorial, sob o fundamento de que o ato delituoso foi ato isolado na vida do agente, eis que $a$ periculosidade é presumida, pois, enquanto não houver a internação do inimputável e não for realizado o exame de verificação da cessação de sua periculosidade, diante da lei existirá sempre a probabilidade da prática de novo fato punível." (Lei de Execução Penal, 1984. Grifo nosso).
} 
novos delitos. Por esse motivo, deverá ser mantido sob a tutela do Estado, por tempo indeterminado.

Várias são as histórias desses sujeitos encarcerados no MJ, alguns há mais de trinta anos, e sobre algumas delas nos deteremos no último capítulo deste trabalho. Concordamos com a autora quanto à importância do trabalho dos profissionais no tratamento aos portadores de distúrbios mentais. Contudo, discordamos, assim como ela, quanto às práticas discursivas - tanto médicas quanto jurídicas -, que tentam justificar a segregação com base na periculosidade do sujeito.

Diante o exposto até aqui, faz-se mister questionarmos em que medida o profissional 'psi' estaria implicado neste processo. Sabe-se que, predominantemente, a função do psicólogo que atua no campo das instituições, baseia-se na confecção dos referidos exames e pareceres, ficando ele, o profissional 'psi', a serviço da justiça, configurando-se entre eles uma confusa e complexa relação: uma espécie de cumplicidade entre os discursos médico - da loucura - e judiciário - da criminalidade (Foucault, 2001). Em outras palavras, poderíamos dizer que o exercício da função do psicólogo no campo institucional fica, basicamente, reduzido à prática de aplicação de dispositivos com o objetivo meramente avaliativo e classificatório. É como se a Psicologia esquecesse a que veio...

Pensamos que, da mesma forma que o sujeito considerado inimputável se sente obstaculizado em resistir às normatizações impostas no campo do instituído, também ao psicólogo esta tarefa torna-se, por vezes, uma tarefa infausta. Na maior parte do tempo, ele se vê aprisionado nos interstícios dos 'jogos de poder' e dos ‘jogos de verdade’, deixando-se enredar por seus discursos e, assim, ele acaba por comprometer-se com a manutenção mesma da ordem vigente. É comum encontrarmos profissionais que apresentam um discurso libertador, mas, geralmente este discurso se mostra desconectado de sua prática.

Afinal, qual a implicação do profissional 'psi' nessa trama? A partir de que princípios ele se adapta ou não às formas de exclusão, marginalização e de controle que esses dispositivos produzem? Em que medida ele se naturaliza ou não com essas tecnologias? Como ele resiste - ou não - aos exercícios de poder e a certas normatizações? 
Trataremos a seguir das problematizações a respeito do uso que os profissionais 'psi' fazem de tais práticas, e de que maneira poderiam resistir a elas. 


\section{O que fazem os operadores da saúde? Reflexões sobre o saber 'psi' e Resistência}

"Sonho com o intelectual destruidor das evidências e das universalidades, que localiza e indica nas inércias e coações do presente os pontos fracos, as brechas, as linhas de força; que sem cessar se desloca, não sabe exatamente onde estará ou o que pensará amanhã, por estar muito atento ao presente; que contribui, no lugar em que está, de passagem, a colocar a questão da revolução, se ela vale a pena e qual (quero dizer qual revolução e qual pena). Que fique claro que os únicos que podem responder são os que aceitam arriscar a vida para fazê-la" ${ }^{\text {,4 }}$.

Indagávamos no Capítulo 3 quais as condições de possibilidade de se produzirem relações de poder no campo institucional que não fossem assimétricas. Pudemos constatar que, embasados nos ensinamentos de Michel Foucault, “a partir do momento em que há uma relação de poder, há também possibilidade de resistência” (Foucault, 1979 b, p. 241). Para ele, há sempre táticas e estratégias a fim de se lidar com o poder.

Contudo, perguntamos, em que medida e como seriam produzidas e manifestadas essas estratégias de resistência? De que maneira poderíamos pensar o poder como relação de forças quando se toma a instituição total como campo de problematização? Uma vez que o poder não é privilégio adquirido da classe dominante (Deleuze, 2005), então de que forma pensá-lo como relação de forças emergida a partir do indivíduo denominado inimputável? Frente a essa realidade hierarquizada e a esses 'jogos de saber/poder' que permeiam as unidades institucionais; mediante a afirmação de Foucault de que o poder provém de todos os lugares; diante da constatação de que as relações de poder implicam sujeitos ativos, como então pensar-se na possibilidade de resistência e de luta dos pacientes inimputáveis, aparentemente assujeitados aos 'jogos de verdade' produzidos como efeito de 'jogos de poder' que atravessam o campo do instituído? De que lugar surgiria o sujeito que resiste, o sujeito capaz de dizer

\footnotetext{
${ }^{44}$ Não ao sexo rei (Foucault, 1979b, p. 242)
} 
não? Sob que condições o paciente inimputável poderia resistir ao poder hegemônico?

E mais: do quê ou de quem dependeria a possibilidade de concretização da passagem de sujeito-sujeitado a sujeito-agente? Não deveria a resistência também manifestar-se através dos chamados 'especialistas’ que operam nas instituições totais, diretamente em contato com o paciente/encarcerado? Em que medida este profissional e as redes de práticas e instituições poderiam contribuir para facilitar o surgimento e a criação de novos modos de subjetivação? Haveria, por acaso, dispositivos acessíveis aos profissionais 'psi’ para a valorização da capacidade de resistência desses pacientes - e de si próprios - para que as brechas de liberdade fossem ampliadas?

Cumpre lembrar, concordando com Foucault, que existem no campo social mesmo milhares de relações de poder, ou seja, relações de forças de pequenos enfrentamentos, microlutas que tratam, na verdade, de batalhas sempre reversíveis (Foucault, 1977c). Com isto, quer-se dizer que ao poder sobre a vida é possível se contrapor a potência de vida: é legítimo dizer-se não ao poder constituído, assim como a criar-se linhas de fuga. Em outras palavras, pode-se afirmar que as relações de poder abrem um campo de possíveis às estratégias de resistência, matéria que iremos tratar a seguir.

\section{1}

\section{Como jogam os operadores da saúde?}

Um dos eixos da obra Vigiar e Punir (1977 a) diz respeito às teses de Michel Foucault sobre o poder disciplinar que se utiliza, inicialmente, de métodos de coerção sobre o corpo, impondo-lhe uma relação de 'docilidade-utilidade’, para depois distribuí-los no espaço, localizando-os, enquadrando-os, classificando-os para, enfim, controlá-los. Esta mecânica de poder define a forma de domínio sobre o corpo dos indivíduos para que estes operem de acordo com as técnicas que são determinas. Assim, diz-se que a disciplina fabrica corpos submissos, corpos ‘dóceis', e ela o faz não apenas através das normas disciplinares, mas, também por meio de técnicas específicas de "um poder modesto, desconfiado, que funciona a modo de uma economia calculada, mas permanente” (Foucault, 1977 a, p. 153) 
que, para tanto, se utiliza de alguns dispositivos, dentre eles, a vigilância hierarquizada e o exame. Como vimos, todo este conjunto de estratégias têm como finalidade medir, controlar e corrigir os chamados anormais. E para tal, para que essas práticas sejam efetivamente exercidas, faz-se mister a presença dos agentes do poder, dentre eles, os profissionais 'psi', os operadores da saúde, aqueles 'especialistas' que se utilizam de um conjunto minucioso de técnicas e de saberes para classificar e nosologizar o 'louco-criminoso' e todos aqueles que ameaçam a harmonia e a conformidade social. Com a extinção dos suplícios - no final do século XVIII -, como forma de causar sofrimento físico ao corpo, agora

o castigo passou de uma arte das sensações insuportáveis a uma economia dos direitos suspensos. Se a justiça ainda tiver que manipular e tocar o corpo dos justiçáveis, tal se fará à distância, propriamente, segundo regras rígidas e visando a um objetivo bem mais 'elevado'. Por efeito dessa nova retenção, um exército inteiro de técnicos veio substituir o carrasco, anatomista imediato do sofrimento: os guardas, os médicos, os capelães, os psicólogos, psiquiatras, os educadores. [...] O corpo supliciado é escamoteado; exclui-se do castigo a encenação da dor. Penetramos na época da sobriedade punitiva. (FOUCAULT, 1977 a, p. 16-18. Grifo nosso).

Ora, se a punição já não se dirige mais ao corpo, sobre o quê, então, ela se exerce? Foucault dirá, simplesmente, que o será sobre a alma. O corpo, agora, é situado dentro de um sistema de privação, de obrigações, de interdições. Assim, gradativamente, novas práticas punitivas vão surgindo e outras modalidades de julgamento vão emergindo sub-repticiamente. Do mesmo modo, a figura do carrasco é substituída, como visto na citação acima, por um coletivo de técnicos os 'psiguranças ${ }^{, 45}$ - que dividem entre si o poder legal de punir. Surgem, destarte, novas instâncias reguladoras que irão classificar e nosologizar a alma 'loucacriminosa'. Thomas Szasz sugere que mais difícil do que classificar os homens é não classificá-los, pois nomear o indivíduo é manter o controle sobre ele, ao invés de “reconhecer sua autonomia e respeitar sua liberdade” (Szasz, 1980, p. 203).

O homem é o único animal que classifica. Tudo que aprendemos ou fazemos deve ser colocado em sua categoria apropriada. Antigamente, quando a Teologia era árbitro supremo entre homens de opiniões conflitantes, as coisas eram mais simples. O homem não classificava. Somente Deus podia fazê-lo. Naquela época, a tarefa do cientista era como a do arrombador: desvendar a misteriosa combinação com que Deus construiu a natureza. A ciência moderna destronou o

\footnotetext{
${ }^{45}$ Criamos o vocábulo para definir a função que o profissional 'psi', equivocadamente, exerce - na grande maioria das vezes -, como se fosse um agente de segurança a serviço da instituição.
} 
Mestre Classificador. E o fez sugerindo uma visão oposta do mundo - na qual tudo é 'uma grande confusão', até que o homem traga ordem e harmonia (SZASZ, 1980, p.180).

Indagaríamos então, se, a partir daí, não seria a presença do profissional 'psi’ vista mais como um personagem moral ao invés de uma figura terapêutica? Não estaria ele corroborando com práticas tecnicistas e normativas produtoras de exclusão? Parece que, sem dúvida, produz-se, no mínimo, uma confusa relação entre a tarefa de punir e a de curar exercida pelos profissionais que operam no campo médico-jurídico.

Ao refletirmos sobre o papel do psicólogo institucional, nos referendamos a uma importantíssima questão problematizada pela pesquisadora e psicóloga Lilia Ferreira Lobo: falar de papel é falar, automaticamente, de representação, ou seja, se o psicólogo acredita ter um papel a desempenhar, seria o mesmo que afirmar que ele crê, implicitamente, em ter que representá-lo. Isto implicaria ser ele o representante dos desejos e necessidades do paciente internado, como se este não o fosse capaz de fazê-lo. Foucault recusa-se a representar o sujeitado, o oprimido, uma vez que acredita ser através de sua própria ação, de seu próprio saber e com sua própria voz que o sujeito se constituirá como sujeito-agente. Acompanhando a visão foucaultiana, a pesquisadora complementa:

Representar é estar no lugar de alguma coisa, é substituir e, profissionalmente, é ter como ocupação falar e agir no lugar do outro. Consequentemente é instituir o silêncio do outro (aquele que é representado), porque quem fala detém a partitura, o texto, as regras e, portanto, o poder de dizer o que é verdadeiro e o que é falso, o que é normal e o que é anormal, criar totalizações teóricas e individuais. Mesmo quando pensamos estar introduzindo um papel renovador e político ao psicólogo, estamos incidindo numa prática de representação, a de traduzir ou interpretar uma verdade oculta, não-dita ou recalcada, para sempre perdida (LOBO, 1997, p.86).

Mais do que isso, este mesmo profissional é - na condição de representante - o porta-voz da instituição: aquele que, crédulo de suas funções de classificar, de diagnosticar e de prover saúde psíquica se vê, ao mesmo tempo, assumindo “a tarefa de despolitizar os fenômenos sociais da delinquência, [...] e da loucura" (Lobo, 1997, 85). Enquanto representante das normas instituídas, não se acha no direito de estranhá-las, muito menos de criticá-las. Torna-se um braço da instituição confundindo, não só a pacientes, como a si mesmo. 'Fechar com a 
equipe’ é o lema a ser seguido submissa e cegamente; confrontá-la ou, simplesmente, questioná-la passa a ser sinônimo de traição. Interessante notar que a psicologia que surgiu das práticas disciplinares e da normalização médica no século XIX, já apontadas por Foucault, subjaz até os dias de hoje no que se refere, especialmente, ao campo da psicologia jurídica. Continuamos fincados em nossas práticas atuais, perpetuando em ações, antigos e ultrapassados dispositivos de saber/poder. Nossas frágeis teorias se coadunam com uma prática ultrapassada e vencida que insiste em se eternizar. Descaso? Indiferença? O que nos impossibilita de vir a empreender outros tipos de análise capazes de desestabilizar o instituído e de interpelar aquilo considerado como o 'sempre foi assim'?

O trabalho do intelectual é referido por Foucault, enquanto questionador de evidências, no sentido de abalar e perturbar o que está naturalizado, em problematizar o que está posto, em desmontar o conhecido, em sacudir o que ‘já lá estava', enfim, o de altercar, o de desfazer os pontos de solda e abri-los para outros campos de possíveis. Concordamos com Lobo (1997) ser necessário postular uma nova indagação, não mais sobre qual seria o papel do psicólogo, senão qual o seu poder e de que maneira poderia exercê-lo.

[...] para localizar as brechas, intervir nas inércias, destruir as evidências é que o psicólogo, tal como um marceneiro ou um mecânico, tem que dispor de ferramentas, não de um papel. [...] As teorias, como as ferramentas, funcionam ou não funcionam, dependendo do que se quer trabalhar. [...] A questão neste caso não seria buscar uma identidade ou prescrever um papel para o psicólogo [...]. Melhor seria pensar como romper as amarras da norma, um dos segredos bem guardados dos jogos de poder, que levam os profissionais das ciências humanas, senão a obstruir o fluxo instituinte das massas, pelo menos a não seguir com elas (LOBO, 1997, p. 88).

Como nos posicionar frente à vida institucional e suas imposições normativas - ao ocuparmos uma função pública - e, ao mesmo tempo, sermos coerentes com nossas convicções políticas? De que maneira lidar com os jogos de poder produzidos no campo do instituído e que tornam determinados conceitos como verdadeiros e definitivos? Como dar conta deste imbróglio produzido entre uma função pública que nos cobra atitudes solidárias às normas de disciplina e de controle institucionais, quando pensamos em direção oposta ao proposto pela instituição? Enfim, parafraseando Foucault no seu belo texto de 1984, A ética do cuidado de si como prática de liberdade, indagaríamos de que maneira o sujeito 
humano entra nos jogos de verdade presentes nas instituições e, como, a partir daí, ele vai se definindo como sujeito falante?

Isto nos remete, mais uma vez, a variedade de dispositivos jurídicopsiquiátricos destinados à avaliação e à classificação dos pacientes e dos condenados pela justiça. É o caso do já mencionado ‘Exame Criminológico’ que, via de regra, é aplicado - à época de ser concedido o benefício do Livramento Condicional - com o objetivo de avaliar o nível de probabilidade do sujeito de voltar ou não a delinquir. Se o profissional 'psi', seguindo as suas convicções e posicionamento éticos, negar-se a elaborar tal exame, ele certamente será punido por sua atitude 'transgressora' às normas do sistema. Assim sendo, como colocarse diante de tal situação, levando-se em consideração a participação de sua função pública juntamente com a assunção de uma posição política assumida?

Para Frédéric Gros, não se trata de recusar um cargo público, mas de aceitá-lo de forma bem clara e definida, ou seja, de não perder a sua identidade social, ainda quando se assume uma função pública.

Cumpro provisoriamente um papel, uma função de comando, sabendo, todavia que a única coisa que devo e posso verdadeiramente comandar é a mim mesmo. E, se me privarem do comando dos outros, não me privarão do comando sobre mim mesmo. Este desprendimento permite, pois, cumprir uma função sem dela jamais fazer sua própria causa, realizando apenas o que está inscrito em sua definição [...] e distribuindo estes papeis sociais, e seu conteúdo, a partir de uma relação constituinte (GROS, 1982, p. 655).

Quanto a este tema Foucault complementa - apoiado nos estoicos -, ressaltando a importância em “definir-se a si mesmo independente da função, papel e prerrogativas, e por isso mesmo poder exercê-los de maneira adequada e racional” (Foucault, 1997, p. 197).

Poderíamos a guisa de exemplificação, mencionar certas situações por nós vividas durante o percurso de trabalho no MJ, algumas delas, nos trazendo graves problemas de ordem jurídica, que acabaram resultando em processo administrativo. Uma delas, citada brevemente no subcapítulo sobre os 'jogos de saber/poder', refere-se ao fato de termos procurado - não antes de nos dirigirmos inúmeras vezes à Direção do MJ -, à Vara de Execuções Penais (VEP) para comunicar o encarceramento inadequado e excessivo dos pacientes no interior das 
'enfermacelas'46, a pretexto de manter a segurança dos mesmos. Por este fato, fomos considerados ‘traidores’ da instituição por 'revelarmos o que lá se passava a pessoas externas a ela'. O efeito de todo esse acontecimento resultou na punição dos envolvidos 'traidores', por termos nos sublevado às normas institucionais em detrimento à defesa dos pacientes, além de termos sido acusados por 'quebra de hierarquia'.

Não deveríamos, por acaso, estar antes preocupados com o bem-estar e com a proteção do paciente ao invés de nos colocarmos a serviço da instituição? Não deveríamos - como profissionais que lidam diretamente com o sofrimento humano -, sair de nossos gabinetes, irmos além do estudo e da elaboração de laudos e pareceres, e atuarmos precisamente no campo? Vale salientar aqui a intervenção feita por Michel Foucault durante a realização de um seminário no Sindicato da Magistratura em Paris no ano de 1977, onde ele postula que a justiça deveria produzir mecanismos de proteção ao indivíduo, antes de se preocupar em tomar a defesa do corpo institucional-administrativo (Foucault, 2004, p. 7).

Com efeito, percebe-se que as formas singulares de intervenção àquilo que está posto e estabelecido, geralmente, são vistas como práticas marginalizadas, desqualificadas e, até mesmo, transgressoras, merecendo, tão somente, o descrédito e a desvalorização do profissional que ousar executá-las. Mais grave ainda: essa depreciação e reprovação não partiram somente das instâncias dirigentes do MJ e demais jurisdições, mas, também dos próprios companheiros da equipe de profissionais de saúde, denominada de 'equipe técnica’.

Façamos aqui um parêntesis para refletirmos a respeito de tal termo utilizado no dia-a-dia referente ao cotidiano deste e dos demais hospitais-prisão. Parece-nos que por 'equipe técnica' entende-se tratar-se de um grupo de pessoas tecnicamente aptas a executar determinadas práticas ou hábeis em aplicar certas técnicas. Nada de errado com isso, não fosse este termo um tanto técnico demais para ser utilizado em um contexto que deveria dizer respeito, mais ao aspecto relativo ao vínculo ou à relação, do que ao de 'técnica' propriamente dito. Por ‘equipe técnica' pode-se também entender como um grupo de pessoas habilitadas a realizar consertos, a fixar objetos, ou aparelhos em geral. De todo modo, apesar

\footnotetext{
${ }^{46}$ Criamos a junção entre os vocábulos ‘enfermaria' e ‘cela' para caracterizar o aspecto prisional e não terapêutico, como se propõe a ser -, do MJ.
} 
da etimologia do vocábulo 'técnica'47 significar 'arte, manufatura', nos parece tratar-se de algo estático, normativo.

Ora, se o próprio grupo de profissionais da instituição se autodenomina como tal, pode parecer que os mesmos lá estão para fixar ou consertar coisas, e não para tratar de sujeitos. Deste modo, o paciente passa a ser visto como um objeto/sujeito a ser consertado/normalizado, e a 'equipe técnica' passa a ser entendida como um time de profissionais destinado a cumprir tarefas, a docilizar corpos e a neutralizar resistências. Torna-se ela, consequentemente, tão dócil quanto aqueles que pretende disciplinar, e segue obedecendo às normas instituídas sem, ao menos, questioná-las. Pensamos, acompanhando Eugenia Vilela, que "os resistentes à ordem ' sempre foram aqueles que possuíam, segundo a expressão de Hannah Arendt, o hábito de viver consigo mesmo de forma explícita” (2001, p. 246). A este 'modo de ser' Michel Foucault denominou de 'ética', assunto que abordaremos um pouco mais adiante neste mesmo capítulo.

Retornando à prática do profissional 'psi', concordamos com Foucault que pensar significa desnaturalizar o que parece evidente ou, ainda, não tomar os fatos como naturais; pensar significa buscar compreender os jogos que determinam o que pode e o que não pode ser dito; pensar é fornecer instrumentos de análise da situação presente, através de uma percepção profunda de tal modo que se possam localizar os pontos aos quais estão ligados os poderes, “fazendo um sumário topográfico e geológico da batalha” (Foucault, 1975, p. 151). Pois, ao se trabalhar no campo mesmo de uma instituição, tal como os manicômios, prisões e afins, não é incomum deparar-se no centro de um campo de batalha - por vezes silenciosa mas, com efeito, uma batalha! E por ser silenciosa, ela torna-se ainda mais perigosa. Portanto, é de suma importância que estejamos atentos a todos os jogos de saber/poder que se insinuam sub-repticiamente, tentando se instituir como postulados sólidos, globais, previsíveis e definitivos, que obstaculizam, sobremaneira, não somente a possibilidade de uma visão crítica dos discursos e das práticas características nesse tipo de instituição, como também de calarem os saberes dominados.

Por saber dominado entendemos uma série de saberes que são desqualificados como saberes ditos comuns, ingênuos, inferiores; saberes

${ }^{47}$ A palavra 'técnica' se origina do grego 'tekhné'. 
singulares, "esses saberes das pessoas que são saberes sem senso comum e que foram de certo modo deixados em repouso, quando não foram efetivamente e explicitamente mantidos sob tutela” (Foucault, 1999, p. 12). Não é incomum constatar-se essa afirmação do autor. Pelo contrário, é bastante comum observarse certos diálogos entre especialista e paciente no interior das 'instituições de sequestro,48, onde o saber 'psi' tenta se estabelecer com seus discursos hierarquizantes - respaldados por uma suposta cientificidade e, portanto, considerados verdadeiros - sobre o saber particular, diferencial e crítico daqueles que ousam se contrapor à unanimidade que os circundam. A este saber desqualificado porque descontínuo e heterogêneo - do psiquiatrizado, do doente, do 'médico paralelo e marginal' em relação ao saber médico -, Foucault (1999) nomeou de 'saber das pessoas': um saber capaz de oposição e de luta contra a tirania do discurso totalitário, científico; um saber feito de crítica; um saber que produz resistência.

Pensamos que caberia aos operadores da saúde recusar os conceitos universais, não por terem causas duvidosas, mas pelo simples fato de que seu conteúdo varia com o tempo e com as circunstâncias (Foucault, 1984b). Em seu $A$ Nau do Tempo-Rei, Peter Pál Pelbart enfatiza a necessidade de uma desconstrução da racionalidade, subsumindo que

a nossa razão, a forma hegemônica de racionalidade vigente é carcerária, mesmo quando ela é edulcorada pelos burocratas do desejo com uma terminologia inefável. Seria preciso desmontar essa racionalidade a fim de deixar o pensamento permeável à desrazão. Isto não significa optar pela irracionalidade [...], mas praticar um trânsito com tudo aquilo que os loucos nos sugerem, embora eles mesmos, por estarem imersos nesse funcionamento exclusivo, tenham sido reduzidos a corpos passivos e impotentes (PELBART, 1993, p. 161).

Mas voltemos à questão dos saberes, proposta por Foucault. Durante o período de nosso trajeto no MJ vivenciamos situações bastante incômodas, provocadoras de um imenso mal-estar. Dentre tantas, parece-nos de suma importância enfatizar uma delas, já brevemente citada no Capítulo 3. Sabe-se que - de acordo com a Lei de Execução Penal ${ }^{49}$-, no que diz respeito à execução das

\footnotetext{
48 Entende-se por 'instituição de sequestro', termo cunhado por Michel Foucault, aquelas que capturam o indivíduo e o colocam dentro de um espaço fechado onde ele vai ser produzido.
}

${ }^{49}$ Lei 7210 de 11 de Julho de 1984. 
Medidas de Segurança quanto à cessação da periculosidade do paciente inimputável, o Art. 176 da referida lei determina que,

Em qualquer tempo, ainda no decorrer do prazo mínimo de duração da medida de segurança, poderá o Juiz da execução, diante de requerimento fundamentado do Ministério Público ou do interessado, seu procurador ou defensor, ordenar o exame para que se verifique a cessação da periculosidade, procedendo-se nos termos do artigo anterior (LEI DE EXECUÇÃO PENAL).

$\mathrm{O}$ artigo anterior ${ }^{50}$ refere-se à época em que o laudo deverá ser elaborado pelo perito forense. Todavia, como se observa no artigo seguinte (Art. 176), é concedido ao próprio paciente o direito de reivindicar por sua desinternação observando-se todos os requisitos exigidos -, ainda que antes do fim do prazo mínimo de duração da medida. Isto significa dizer que o sujeito é legalmente reconhecido e autorizado a externar o saber sobre si mesmo: é ele, e não apenas o saber médico, quem solicita a revogação da sua medida de segurança. Esta inversão de conhecimento proporciona ao sujeito/ paciente manifestar-se, e é exatamente sobre esta manifestação de saber exercida por aqueles que, usualmente não o exercem, que Foucault denominou de 'saberes sujeitados', como refletíamos há pouco, ou seja, "saberes que estavam desqualificados como saberes não conceituais, como saberes insuficientemente elaborados: saberes ingênuos, saberes hierarquicamente inferiores, saberes abaixo do nível de conhecimento" (Foucault, 1999, p. 12).

Quando o paciente mesmo manifesta o saber sobre si, ele exerce, ao mesmo tempo, um poder sobre aqueles que procuram inabilitá-lo, fragilizá-lo. Portanto, é essencial que esses saberes desqualificados, não legitimados, intervenham sobre a instância teórica e unitária da instituição, que tenta filtrar, ordenar e tutelar esses saberes locais em nome de um saber científico.

Assim sendo, indagamos se não caberia ao profissional 'psi' exercer - à semelhança do que faz o paciente -, sua análise crítica e sua resistência em relação ao saber 'vindo de cima', aquele que supõe saber mais do que o próprio sujeito sabe de si. E mais: não caberia a ele procurar reativar e intensificar os saberes ditos menores, mantidos sob a tutela dos saberes vinculados à instância médicajurídica, intervindo de modo que eles possam se exercer com liberdade?

\footnotetext{
${ }^{50}$ Art. 175. A cessação da periculosidade será averiguada no fim do prazo mínimo de duração da medida de segurança, pelo exame das condições pessoais do agente, observando-se o seguinte [...].
} 
No caso da solicitação do exame de cessação de periculosidade partindo do paciente mesmo, não deveria o profissional, não somente incentivar o paciente a fazê-lo, como também agilizar os meios para que o referido exame fosse, de fato, realizado? Contudo, na prática, a teoria no MJ era outra... Nós - os operadores da saúde -, optávamos pelo silêncio cauteloso, pela prudência taciturna, pela fraqueza, pela negação absoluta em relação à existência do Art.176 da Lei de Execução Penal. Os que se aventuravam a pô-lo em evidência - tanto o paciente quanto o profissional 'psi' -, costumavam ser vistos como insurgentes, costumavam se vistos como traidores mesmo da instituição.

\section{2}

\section{Estratégias de resistência: procurando saídas na prática}

"Mesmo quando a relação de poder é completamente desequilibrada, quando verdadeiramente se pode dizer que um tem todo o poder sobre o outro, um poder só pode se exercer sobre pó outro à medida que ainda reste a esse último a possibilidade de se matar, de pular a janela ou de matar o outro. Isso significa que, nas relações de poder, há necessariamente possibilidade de resistência, pois se não houvesse possibilidade de resistência - de resistência violenta, de fuga, de subterfúgios, de estratégias que invertam a situação -, não haveria de forma alguma relações de poder". 51

Como já visto anteriormente, a tese foucaultiana sustenta que onde há poder, há resistência. É como se na aparente assimetria do campo de poder, houvesse uma simetria de base, onde ambos os lados são afetados, podendo-se, assim, constatar que, a despeito do poder instituído, há algo que acontece nos interstícios das relações; e este algo é, exatamente, a resistência. Parece, portanto que, a relação de poder e as forças que resistem não podem ser separadas uma da outra. Em O sujeito e o poder Foucault esclarece que

[...] no centro da relação de poder, provocando-a incessantemente, encontra-se a recalcitrância do querer e a intransigência da liberdade. Mais do que um "antagonismo" essencial, seria melhor falar de um "agonismo" - de uma relação que é, ao mesmo tempo, de incitação recíproca e de luta; trata-se, portanto, menos de uma oposição de termos que se bloqueiam mutuamente do que de uma provocação permanente (FOUCAULT, 1995a, p. 244-245).

\footnotetext{
${ }^{51}$ A ética do cuidado de si como prática de liberdade (Foucault, 1984a, p. 277).
} 
Aurora, paciente do setor feminino, se nega a ir a uma comemoração de aniversário, caso não possa usar vestes comuns, ao invés do uniforme do hospital $^{52}$. A partir desta situação poderíamos analisar a questão do poder sob dois ângulos distintos: entendendo-o da maneira tradicional, como aquele poder que impede o sujeito de exercer as suas próprias forças, produzindo-se, assim, um sujeito-sujeitado. Neste caso, teríamos o exemplo da escravidão e de algumas situações de tortura. Mas, ao falar de poder, Foucault se refere a algo que se faz sempre presente e que se exerce como uma multiplicidade de relações de forças. É como se o poder incitasse, estimulasse Aurora não a reagir, mas sim, a resistir. E é sob esse ângulo que o poder é visto como resistência: "Não coloco uma substância da resistência face a uma substância do poder. Digo simplesmente: a partir do momento em que há uma relação de poder, há uma possibilidade de resistência” (Foucault, 1979 b, p. 241).

Assim, entendemos que as relações de poder tratam, mais do que um confronto, de um combate entre sujeitos ativos. Parece claro, portanto, que a produção das relações de poder não se faz apenas de cima para baixo: ela se manifesta como relações de forças, onde ambos os lados afetam e são afetados, isto é, "para que haja um movimento de cima para baixo, é preciso que haja ao mesmo tempo uma capilaridade de baixo para cima” (Foucault, 1979 b, p. 250).

Deste modo, poderíamos constatar que toda relação de poder implica numa estratégia de luta, e que no centro de toda relação de poder, lá está ela: a resistência. Segundo o autor, aquilo que define uma relação de poder é um modo de ação que age diretamente sobre uma outra ação. Portanto, é possível sustentar que o poder é algo construído e transformado pela força da resistência e é a partir da análise dessas resistências que se pode conhecer as estratégias e mecanismos que lhe são próprios. Levando-se em consideração que, como leciona Foucault, há resistência e capacidade de dizer não em todo e qualquer sujeito, acredita-se que há resistência também no paciente inimputável. Sem dúvida, podemos entendê-la como um desejo singular que se insurge contra a norma e sobre as suas estratégias de dominação.

\footnotetext{
${ }^{52}$ De acordo com as normas do Manicômio Judiciário, é proibido às pacientes femininas - mas não aos pacientes masculinos -, vestirem-se com suas próprias roupas. Elas são obrigadas a se manter uniformizadas, ainda que nas comemorações e festividades quando, naturalmente, desejassem se vestir com 'roupa de festa'.
} 
Se admitirmos que a resistência possa ser vista como uma potência se insurgindo sobre tais estratégias de dominação, manifestando-se através de movimentos que lutam contra o poder instituído, haverá chances de acreditarmos que existe resistência em todos os humanos. Ao ser questionado por JacquesAlain Miller ${ }^{53}$ sobre quem seriam os nossos inimigos ou quem são os sujeitos que se opõem entre si, Foucault responde: "Nós lutamos todos contra todos. Existe sempre algo em nós que luta contra outra coisa em nós mesmos” (Foucault, 1978 b, p. 257).

Por conseguinte, embasando-nos no argumento do autor, de que o poder é sempre produtivo, podemos também considerar ser possível ao sujeito inimputável resistir aos mecanismos coercitivos e adaptativos presentes nas instituições. Pensamos então o poder como produtor de uma luta de forças, onde os sujeitos tomam suas posições estratégicas, tanto no combate/relação com o outro, como consigo mesmo. Deste modo, constata-se que o poder não opera através da violência e da repressão, mas tão somente ele se exerce numa microrelação de forças, suscitando e incitando os indivíduos a resistir. Portanto, ao refletirmos sobre as condições de possibilidade do sujeito - encarcerado ou não em procurar transformar aquilo que lhe é imposto, tanto pelas determinações sociais quanto pelas institucionais, constatamos os infinitos mecanismos por eles utilizados com o intuito, não somente de inventar novas 'maneiras de viver', criando formas de resistência a este instituído.

Além de Michel Foucault, consideramos um outro autor que se faz indispensável para o enriquecimento de nossa problematização. Ei-lo:

Se é verdade que por toda a parte se estende e se precisa a rede de "vigilância", mais urgente ainda é descobrir como é que uma sociedade inteira não se reduz a ela: que procedimentos populares (também 'minúsculos" e cotidianos) jogam com os mecanismos da disciplina e não se conformam com ela a não ser para alterá-los; enfim, que "maneiras de fazer" formam a contrapartida, do lado dos consumidores (ou "dominados"?), dos processos mudos que organizam a ordenação sócio-política (CERTEAU, 2005, p. 41. Grifo nosso).

\section{Foucault complementa:}

O grande jogo da história será de quem se apoderar das regras, de quem tomar o lugar daqueles que a utilizam, de quem se disfarçar para pervertê-las, utilizá-las ao inverso e voltá-las contra aqueles que as tinham imposto; de quem, se

\footnotetext{
${ }^{53}$ Foucault é entrevistado por vários psicanalistas, dentre eles o francês Jacques-Alain Miller.
} 
introduzindo no aparelho complexo, o fizer funcionar de tal modo que os dominadores encontrar-se-ão dominados por suas próprias regras. As diferentes emergências [...] são efeitos de substituição, reposição e deslocamento, conquistas disfarçadas, inversões sistemáticas (FOUCAULT, 1979 d, p. 25-26).

Michel de Certau e Michel Foucault foram contemporâneos e nutriam mútua admiração. Ambos franceses, nascidos respectivamente em 1925 e 1926 e falecidos prematuramente - Certeau aos 61 anos e Foucault aos 58 - em um intervalo de apenas dois anos de diferença (1986 e 1984). Os 'dois Michel' preocupavam-se em desnaturalizar aquilo que se apresentava como definitivo, predeterminado, evidente e imutável. Ambos acreditavam na possibilidade do sujeito em criar e recriar o seu cotidiano. Sempre.

Certeau, ao longo de sua obra, contribuiu sobremaneira para o entendimento a respeito da capacidade de criatividade das pessoas comuns em driblar o instituído, em encontrar 'maneiras de fazer' que subvertem a ordem dominante, em não se conformarem com o que lhes é determinado, utilizando para isso, as práticas de 'invenção do cotidiano’ (Certau, 2005). De acordo com o autor, é através das 'artes de fazer’ que se resiste ao poder. Em seu $A$ invenção do cotidiano - dedicado ao 'homem ordinário' -, o autor problematiza a arte de viver a sociedade de consumo no que diz respeito aos modelos de ação característicos dos consumidores. Seguindo os seus ensinamentos - de que podemos criar sobre o já criado -, nos apropriamos desta idéia para pensar de que maneira a sua teoria poderia ser também utilizada em relação aos modos de subjetivação e de resistência do sujeito internado nos nosocômios.

Passamos a nos indagar sobre essa questão ao perceber a sensibilidade de Certeau em acreditar na inventividade do mais fraco, na força do indivíduo para se apropriar e alterar - através de pequenos golpes e astúcias - o modo de viver na sociedade contemporânea. Segundo ele, nas ações cotidianas ou 'artes de fazer', resiste-se, inventa-se.

A uma produção racionalizada, expansionista além de centralizada, barulhenta e espetacular, corresponde outra produção, qualificada de "consumo": esta é astuciosa, é dispersa, mas ao mesmo tempo ela se insinua ubiquamente, silenciosa e quase invisível, pois não se faz notar com produtos próprios, mas nas maneiras de empregar os produtos impostos por uma ordem econômica dominante (CERTEAU, 2005, p.39. Grifo nosso.) 
Acreditamos, assim, estar o sujeito em constante transformação, recriandose a cada embate com as circunstâncias que se apresentam. Em Tornar-se quem se é, Silvia Pimenta Velloso Rocha reflete que a cada um desses embates, o sujeito vai se constituindo como numa "reinvenção de caráter sempre aberto, provisório, contingente" (Rocha, 2006, p. 270). A autora traz, de maneira bastante interessante, a metáfora da água como imagem de transformação, dada a sua capacidade - por sua maleabilidade - de assumir uma infinidade de formas diferentes, modificando-se a cada novo relevo que se introduz. Isto nos leva a pensar - trazendo à tona o ponto de vista foucaultiano, já discutido em capítulo anterior -, que a cada transformação novos pontos de vista se inserem, instaurando-se, assim, novas verdades.

Mas, voltemos a Certeau. Segundo Roger Chartier, o autor não gostava de se autodefinir, nem tampouco de se encerrar em uma categoria acadêmica. Preferia considerar-se um historiador, um viajante. Toda a sua obra centralizou-se na análise

de las práticas mediante las cuales los hombres y las mujeres de una época se apropian, a su manera, de los códigos y los lugares que les son impuestos, o bien subvierten las reglas comunes para conformar práticas inéditas. Las práticas del lenguaje de la mística son emblemáticas de esas "artes de hacer" o "hacer com" que desvían los materiales de que se apoderan (CHARTIER, 1996, p. 70-71) ${ }^{54}$.

Inventando o cotidiano, Michel de Certeau constata a existência oculta de redes de astúcias sutis e, muitas vezes silenciosas, que vão criando possibilidades ao sujeito a inventar uma maneira própria de caminhar pelas vielas do cotidiano, pelos labirintos das práticas instituídas (Certeau, 2005). Não importa qual seja este instituído: um produto a ser consumido ou um modelo institucional a ser seguido. Esta maneira de ser e de se situar na vida, caminha na contramão, como um movimento de resistência àquilo que está posto, àquilo que está naturalizado. Apesar do autor se ocupar com os modelos de ação característicos dos sujeitos que, através das 'artes de fazer', inventam o cotidiano, também ele se mostrou um estudioso na análise sobre as questões institucionais, procurando pensar o

\footnotetext{
54،[...] das práticas mediante as quais os homens e as mulheres de uma época se apropriam, à sua maneira, dos códigos e dos lugares que lhe são impostos, ou subvertem as regras comuns para moldar práticas inéditas. As práticas de linguagem do misticismo são emblemáticas dessas "artes de fazer" ou "fazer com" que desviam os materiais dos quais se apoderam" (Tradução nossa).
} 
'estranho' com o qual nos deparamos na vida coletiva, assim como o 'estranho' que nos habita, qual seja, a vivência mesmo da loucura.

Por sua vez, Michel Foucault, semelhante a Certeau, pensa o sujeito e a história em termos de descontinuidade, de singularidade, com temporalidades distintas. Assim, podemos constatar que a perspectiva foucaultiana usaria a história para romper com o presente, para desestabilizá-lo, para desnaturalizá-lo. Trata-se de uma perspectiva desconstrutivista, pronta para "rir das solenidades da origem” (Foucault, 1979 d, p. 18). Crítico do viés historicista, não no sentido de negar a história, mas no sentido de recusar o conceito de história atrelado à idéia de origem, à idéia de uma verdade única e primeira, o autor reflete:

A história [...] não tem por fim reencontrar as raízes de nossa identidade, mas ao contrario, se obstinar em dissipá-la; ela não pretende demarcar o território único de onde viemos [...]; ela pretende fazer aparecer todas as descontinuidades que nos atravessam (FOUCAULT, 1979 d, p. 35).

Para ele, o sujeito é todo tempo atravessado, não só pelas contingências e pelo aspecto fortuito da vida, mas também pelas regras e exigências que se nos impõem através dos jogos de saber/poder que nos constitui. Assim, não existe 'o' sujeito, mas um sujeito em constante transformação, reinventando-se sempre, criando novas saídas, construindo novos percursos. A história, segundo Gilles Deleuze (1992), circunscreve e entremeia o sujeito sem, contudo, fixar ou prescrever quem ele é, mas aquilo de que está em vias de diferir. Para ambos os autores, tanto as astúcias dos consumidores - referidas por Certeau -, como as estratégias de antidisciplinas, mencionadas por Foucault, surgem como resistência às imposições científicas e sociais. Questionamos se, deste modo, não estaria o sujeito internado nos nosocômios - na categoria de paciente inimputável -, procurando resistir ao que lhe é instituído? Ao tentar resistir, Aurora não estaria criando, como nos ensina Certeau, modos de burlar e de driblar o sistema com o intuito de preservar a sua condição mesma de sujeito-agente?

Poderíamos considerar que, assim como qualquer outro indivíduo, o sujeito inimputável ora se encontra em estado de sujeição, ora se encontra no comando, exatamente como num jogo, como num combate. Diríamos que são forças em tensão. É importante pensar em práticas de liberdade e práticas de 
sujeição caminhando lado a lado de onde, inclusive, surgiria a resistência, constatando-se, assim, que o assujeitamento nunca é total. Servindo-se da resistência como uma ferramenta que o faz continuar lutando contra aquilo que tenta se lhe sobrepor como definitivo, verdadeiro, natural e a priori, o sujeito aponta para o novo, para algo a ser produzido, para uma prática de liberdade (Foucault, 1984 a). Consequentemente entende-se resistência como criação, produção, como a força que move a história.

Indagamos, então: de que maneira o profissional 'psi' e toda uma rede de práticas e instituições, poderia contribuir para facilitar o surgimento e a criação de novos modos de subjetivação do sujeito encarcerado?

Pensamos que, da mesma forma que ao inimputável faz-se difícil reagir às normas institucionais, também ao psicólogo ocorrem dificuldades semelhantes. Na maior parte das vezes ele se vê enredado nos interstícios dos jogos de poder e dos jogos de verdade que permeiam o campo do instituído, deixando-se atrelar por seus discursos e, comprometendo-se, assim, com a manutenção da ordem vigente. É comum encontrarmos o profissional 'psi' que apresenta um discurso libertador, mas, absolutamente desconectado da sua prática. O seu falar não encontra ressonância em suas ações. Franco Basaglia, psiquiatra italiano, nos brinda com vigoroso e consistente comentário a respeito:

Não é verdade que o psiquiatra tenha duas posturas, uma como cidadão do Estado e outra como psiquiatra. Há somente uma: como homem. E como homem eu quero mudar a vida que levo, e para isso tenho que mudar essa organização social, não com revolução, mas apenas exercendo minha profissão de psiquiatra. Se todos os profissionais exercessem sua profissão, isso seria a verdadeira revolução. Mudando o campo institucional no qual eu trabalho, mudo a sociedade, e se isso for onipotência, viva a onipotência! (BASAGLIA, 1982, p. 150).

Parece-nos claro, portanto, que o profissional de saúde mental deva ser, antes de mais nada, crítico de suas condições de trabalho, pois sabemos que o campo do instituído com suas regras, hierarquias e conformação de espaço/tempo, acaba por assimilar os saberes ditos científicos - oriundos da psiquiatria, da psicologia e também do direito -, tomando-os como discursos de verdade. Assim sendo, ele corre o perigo de tornar-se, ele próprio, como profissional e como homem, reduzido ao silêncio (Veyne, 2004). 
De que maneira, então, seria possível produzirem-se práticas de saúde que não se tornem simples repetição de modelos herméticos e universais? Como fazer surgir novos modos de invenção do campo do instituído, a despeito de suas forças hegemônicas que remam incessantemente em direção oposta?

Mais uma vez, os 'dois Michel' se complementam no que diz respeito às possibilidades de produção de novos modos e maneiras de ser, através, segundo Certeau, do uso de táticas e estratégias, que são nada menos do que a capacidade de resistência presente em todo e qualquer sujeito, conforme também constata Foucault. Enquanto que para Certeau, “o cotidiano se inventa com mil maneiras de caça não autorizada” (2005, p. 38), para Foucault, “jamais somos aprisionados pelo poder; podemos sempre modificar sua dominação em condições determinadas e segundo uma estratégia precisa”. (1979 b, p. 241). O que nos leva a pensar que podemos e devemos nos insurgir contra a dominação, tentando lutar e subverter as relações perversas do poder, os enunciados definitivos sobre a verdade e, assim, podendo criar um mundo onde as subjetividades possam aflorar na sua diferença e alteridade e, principalmente, visando a constituição de um novo sujeito histórico.

Acompanhando Foucault, acreditamos que não exista 'a verdade', mas verdades que vão se recriando sempre, podendo-se atribuir, a cada uma delas, várias e diferentes interpretações. É, portanto, através da instauração de novas verdades que o indivíduo vai se constituindo, criando-se a si próprio como sujeitoagente, historicamente em constante transformação, produzindo, a cada momento, novos meios de subjetivação. Dentro desta visão, entendemos o sujeito como aquele que, não somente se deixa regrar por valores, mas também aquele que é capaz de interrogar-se sobre esses valores e que, segundo Benilton Bezerra (2009), "seja capaz, em função dos dilemas que a vida lhe coloca, de tentar modificar o mundo em sociedade”.

É como se o poder estimulasse o sujeito a resistir. Sem dúvida, a resistência se define nas relações de poder, isto é, não se trata de uma capacidade inata que antecede a relação; mas, de fato a resistência ocorre na relação mesma. Para Foucault, ela pressupõe um sujeito ativo, capaz de dizer não. Ao analisarmos o campo do instituído, podemos notar que, apesar de não ocorrer com muita frequência, é possível observar-se um ou outro paciente que se nega a conversar 
com algum profissional da equipe que o atende. Uma vez não fosse esse comportamento visto como uma atitude de insubordinação - pelos profissionais mesmo do MJ -, poderíamos entendê-lo como um direito do paciente em não querer falar e, como assegura Bezerra, é neste momento - do querer exercer a liberdade - que o sujeito passaria da condição de sujeito-submetido a sujeitoagente. Concordando com o autor, podemos afirmar, com efeito, que não estamos condenados ao poder; é possível resistir a ele, criar linhas de fuga. Corroborando com esta idéia, trazemos a confirmação vinda de Certeau:

[...] Cada vez mais coagido e sempre menos envolvido com esses enquadramentos, o indivíduo se destaca deles sem poder escapar-lhes, e só lhe resta a astúcia no relacionamento com eles, "dar golpes", encontrar na megalópole eletrotecnicizada e informatizada a "arte” dos caçadores ou dos rurícolas antigos (CERTEAU, 2005, p. 52).

Vemos, assim, nesses dois autores a preocupação em enfatizar a potência de vida presente no homem, seja ele quem for. Diríamos mais ainda: ambos se dedicam e se voltam ao 'homem comum', ao 'homem ordinário', aquele que inventa o cotidiano através das 'artes de fazer' e das táticas de resistência (Certeau, 2005). Ou como sustenta Foucault, aos 'homens infames', “àquelas pessoas absolutamente sem glória [...] que não mais existem senão através das poucas palavras terríveis que eram destinadas a torná-los indignos para sempre da memória dos homens” (Foucault, 1977 d p. 210).

Deste modo, através de Certeau e Foucault certificamos a necessidade de se problematizar o papel do profissional 'psi' no que diz respeito à sua implicação e intervenção dentro do campo da saúde mental. Estamos nos referindo às práticas de resistência ao poder instituído, tanto por parte do sujeito internado quanto do próprio profissional 'psi'. Ao criar o GIP (Groupe d'Information sur les Prisons) ${ }^{55}$ Foucault se ocupou por preferir, segundo ele próprio, “um trabalho efetivo à loquacidade universitária e aos rabiscos de livros. [...] uma ação política concreta em favor dos prisioneiros” (Foucault, 1972 a, p.291). Ao organizar essa prática coletiva, Foucault criou condições para que os presos pudessem falar por si

\footnotetext{
${ }^{55}$ O Groupe d'Information sur les Prisons (GIP) foi um movimento de ação e de informação criado em 1971 com o objetivo de dar a palavra aos presos e, ao mesmo tempo, de permitir a mobilização de intelectuais e profissionais envolvidos no sistema prisional francês. Este movimento resultou na entrada da imprensa às prisões, condição até então negada pelas autoridades competentes da época.
} 
mesmos. No GIP todos podiam falar e, segundo o autor, qualquer um que tomasse a palavra, falava não porque tinha um título ou um nome, mas, simplesmente porque tinha algo a dizer. Para ele, a única palavra de ordem do GIP era 'aos detentos, a palavra!'. Sua intenção não era outra senão a de dar a palavra àqueles que viviam no interior das prisões, ao invés de falar por ou sobre eles. Levando-se em consideração a presença, segundo Certeau, de relações de forças entre o fraco e o forte, pensamos que a ação de Foucault no GIP se manifesta como uma resistência que, desta vez, parte do pesquisador mesmo.

Todavia, como se sabe, as instituições são dispositivos que produzem ‘subjetividades sujeitadas' (Maciel, 2011), dadas as suas características de disciplina e de controle. Sendo assim, faz-se mister a criação de focos de resistência dentro do campo institucional mesmo a fim de que se possam produzir ‘subjetividades livres', capazes de realizar escolhas. Ao se impedir, por exemplo, que o paciente do MJ possa optar em querer participar ou não de uma atividade terapêutica, minam-se as condições de possibilidades deste sujeito em se afirmar como sujeito-agente, facilitando, inversamente, a produção de condutas de submissão.

É imprescindível colocarmos em questão algumas problematizações a respeito das ações desses pacientes que, a despeito da pressão exercida pelos jogos de poder no campo do instituído, apresentam maneiras de resistir, o que nos leva a concordar quando afirma Eduardo Passeti (2011) de que “o sujeito se constitui ao ser impedido de fazê-lo”. Dito de outra maneira e, aproveitando para citar Foucault, "é porque há possibilidade de resistência e resistência real que o poder daquele que domina tenta se manter com tanto mais força, tanto mais astúcia, quanto maior for a resistência” (Foucault, 1977 c, p. 232).

Podemos então sustentar que o sujeito se constitui através da imposição do poder e da resistência exercida sobre ele, ou seja, é exatamente neste jogo de embate entre forças antagônicas que podemos pensar na produção de uma brecha anunciando a entrada de novas práticas e saberes e, assim sendo, de novas formas de subjetivação. Por conseguinte, isto nos leva a pensar que podemos e devemos nos insurgir contra a dominação; podemos lutar e subverter o que está posto e instituído, criando um mundo onde as subjetividades possam aflorar na sua diferença e alteridade. E, principalmente, visando-se a constituição de um novo 
sujeito histórico. Constatamos, assim, que é na resistência - potência que se insurge sobre as estratégias de dominação - que o sujeito escapa do lugar das origens, rompendo com o que está posto.

De acordo com Didier Eribon (2004), não se trata de ser fiel a uma teoria, mas sim, a uma atitude, a um estilo de vida, a qual Foucault denominava de 'atitude crítica': “La crítica es la verdad sobre sus efectos de poder y al poder sobre sus discursos acerca de la verdad; la crítica sería el arte de la insumisiíon voluntaria, el de la indocilidad reflexionada”(Eribon, 2004, p.22) ${ }^{56}$ Entendemos, pois, a crítica como uma atitude, como uma forma mesmo de resistir ao conjunto de dispositivos que comandam a conduta dos sujeitos. A atitude crítica seria, então, uma prática de não aceitação daquilo que nos é determinado, um permanente questionamento do "porque sempre foi assim”, uma resistência às formas de assujeitamento. A atitude crítica nada mais é do que a ética mesma. Para Eribon (2004), trata-se de refletir e subsumir aquilo que Foucault

nos transmitió y el êthos que quería valorizar: el gesto incansable de la crítica radical y a exigencia de um pensamiento que nunca debe dejar de cuestionar las evidencias del mundo que nos rodea, y los poderes o instituiciones que se ensañan en perpetuarlas (ERIBON, 2004, p. 22). ${ }^{57}$

Para Foucault o êthos é visto como a junção de atitude e exercício, como uma forma de ser consigo mesmo, com o outro, e com a verdade, ou seja, uma atitude ética, como um 'modo de ser'. A ética, tal como entendida por ele, é “um exercício de si sobre si mesmo, através do qual se procura elaborar, se transformar e atingir um certo modo de ser” (Foucault, 1984 a, p. 265). Dito de outra maneira, trata-se da relação que se estabelece consigo mesmo, uma 'prática de si ${ }^{\text {, }}$, uma 'estética da existência',59 (Foucault, 1995 b) que determina a maneira pela qual o

\footnotetext{
56 “A crítica é o movimento pelo qual o sujeito se dá o direito de questionar a verdade sobre seus efeitos de poder e o poder sobre seus discursos de verdade; a crítica seria a arte da insubordinação voluntária, aquela da indocilidade refletida" (Tradução nossa).

57 “[...] nos transmitiu e o êthos que queria valorizar: o gesto incansável da crítica radical e a exigência de um pensamento que nunca deve deixar de questionar as evidências do mundo que nos rodeia, e os poderes ou instituições que insistem em perpetuá-las” (Tradução nossa).

${ }^{58}$ A expressão 'práticas de si' ou 'saber de si', dentro da concepção foucaultiana, refere-se ao conjunto das relações que o indivíduo pode estabelecer consigo mesmo, dentro do domínio de uma ética. Prática de si, hermenêutica de si, cuidado de si, saber de si, ou seja, as relações que o indivíduo estabelece consigo mesmo, e ao que Foucault chamará de ética (Fonseca, 2002, p. 42).

59 "O conceito de estética não é sinônimo de beleza ou a busca hedonista do gozar a vida; ele remete a um exercício da sensibilidade em relação ao mundo. Essa sensibilidade, ou seja, o deixar-
} 
indivíduo constitui a si mesmo como sujeito moral de suas próprias ações. Uma prática reflexiva da liberdade, a qual inclui, necessariamente, a nossa relação com a loucura, não apenas a partir de um tal saber sobre a doença mental ou uma tal atitude diante do homem alienado, mas desde um olhar isento de preconceito em relação a este outro.

Ao problematizar a questão da ética, o autor retorna aos textos gregos e constata que na ética grega as pessoas estavam muito mais preocupadas consigo mesmas e com os outros do que com quaisquer aspectos dos sistemas social ou jurídico: a sua preocupação era constituir um tipo de ética que fosse uma 'estética da existência', ou seja, a possibilidade de um trabalho de si para si onde se poderia transformar a vida mesma numa obra de arte, ocupando-se de si mesmo, através de um 'cuidado de si' (Foucault, 1984 a). Em outras palavras, trata-se de criar-se sem se servir das regras universais, sem se apegar aos saberes já instituídos e naturalizados, enfim, "a partir da ideia de que o eu não nos é dado, creio que há apenas uma conseqüência prática: temos que nos criar a nós mesmos como uma obra de arte” (Foucault, 1995 b, p. 262). Com isto o autor sugere que o sujeito deve conservar o controle sobre sua vida, intervindo constantemente sobre ela, como se tratasse de uma obra de arte. Sustenta ainda que esse projeto do sujeito sobre si mesmo se dá através de uma longa prática e de um trabalho diário que nunca se conclui.

Nos últimos textos foucaultianos, a noção de sujeito - até então visto como efeito de práticas discursivas e não discursivas, e de relações de saber/poder -, passa a ser problematizada não somente como sendo produto dessas práticas e relações, mas também, ele próprio, como produtor de si mesmo, com uma certa autonomia, um quantum de resistência de modo que possa ser pensado além do dispositivo saber/poder. O autor passa a se interessar, de fato, pela maneira com a qual o sujeito se (auto) constitui de uma maneira ativa, através das 'práticas de si', sendo capaz de lidar com as técnicas de dominação que atuam sobre ele, compondo, assim, uma estratégia que mescla a maneira como o querem conduzir e a maneira como ele se conduz. Trata-se aqui de um sujeito ético, distinto do sujeito sujeitado (Foucault, 1995 a).

se afetar pelo outro (no sentido de Spinoza), é um dos elementos indispensáveis para a prática reflexiva da liberdade" (Nardi e Silva, 2009, p.102). 
Não existe aí nenhuma intenção em se descobrir uma verdade escondida no interior do sujeito, mas sim de tentar determinar o que ele pode ou não fazer com uma liberdade disponível; trata-se, pois, não de decifrar, mas de construir. Assim, ao se referir ao ato de interrogação da verdade, Foucault propõe não a busca de uma verdade, mas das inúmeras verdades que o sujeito é capaz de articular, possibilitando-o a desafiar "uma certa ordem de governabilidade" (Echavarren, 2011, p. 10), capaz de tirá-lo de um estado de tutela e direcioná-lo à condição de autonomia. Melhor dizendo, o autor sustenta que a atitude crítica, a interrogação da verdade, a interpelação do real, viabiliza a saída de um estado de servidão, de sujeição, levando, em contrapartida, à liberdade da razão, à autonomia sobre a vida mesma. A atitude crítica é um escape, uma via de saída que livra o sujeito do estado de tutela (Foucault, 2010 c). Assim, acompanhando a tese foucaultiana, acreditamos que a tarefa do profissional da saúde deva ser a de reflexão e de atitude crítica permanente em relação à sua prática, lutando sempre contra as manobras de sujeição, tanto aquelas que são aplicadas ao paciente encarcerado, quanto as que lhe são imputadas a si próprio.

As técnicas para se relacionar consigo mesmo como um sujeito de capacidades singulares, digno de respeito, vão contra as práticas para se relacionar consigo próprio como o alvo da disciplina, do dever e da docilidade (ROSE, 2010, p. 48).

Consequentemente, as invenções cotidianas representam as diferentes formas de os profissionais psi se adequarem - mas não de se conformarem - às estratégias presentes no campo institucional, criando recursos que promovam a reorganização e a recriação do dia-a-dia de suas práticas. Tais invenções vão, por outro lado, gerando novos saberes e viabilizando, assim, condições de possibilidade para que o próprio paciente possa resistir ao que lhe é imposto. Deste modo acreditamos em uma possível mudança na concretude do cotidiano manicomial.

Não obstante o papel do profissional de saúde encontrar-se atrelado a um sistema de poder, funcionando como mais uma peça da engrenagem institucional, paradoxalmente, esse lugar leva o mesmo profissional, tanto a utilizar intervenções normatizadoras e adaptativas, quanto a produzir práticas que promovam a criação de novas aberturas e de novos modos de produção de subjetividades. Assim como o GIP mobilizou os intelectuais franceses a 
trabalharem ao lado dos detentos, Felix Guattari e Suely Rolnik (1986) nos advertem, igualmente, de que não há mais porque se aceitar falsas neutralidades. Destarte, entendemos que a tarefa do profissional 'psi' é a de se inquietar, de se surpreender diante das verdades absolutas, diante do estagnado e, a partir daí, questionar os jogos presentes no campo do instituído, desmontando a 'historia oficial', descolando os pontos de solda, possibilitando novos desenhos e novas verdades passíveis de transformação.

Indo um pouco mais além - e diríamos, de forma ousada e provocativa -, Peter Pál Pelbart (1993) sugere que o profissional 'psi' possa, enfim, desarrazoar... De acordo com o autor, não se trata de gritar novas palavras de ordem em substituição às antigas, pois,

a desrazão não é uma nova ideologia, muito menos uma nova tecnologia - mas o exercício, no seio do próprio pensar e das práticas sociais, de uma nova forma de relacionar-se com o acaso, com o desconhecido [...]. Trata-se de não burocratizar o acaso com causalidades secretas ou cálculos de probabilidade, mas fazer do acaso um campo de invenção e imprevisibilidade; de não recortar o desconhecido com o bisturi da racionalidade explicativa [...]. Trata-se enfim de um pensamento que não transforma a força em acúmulo, mas em diferença e intensidade (PELBART, 1993, p.107).

Por conseguinte, o operador da saúde não pode se deixar apaziguar nem deixar de se surpreender com aquilo que está posto, nem tampouco em adaptar-se à cronicidade do instituído. Ou ele se adéqua às praticas e instrumentos teóricos pré-estabelecidos e, dessa forma se identifica maciçamente com os valores institucionais, ou ele tenta desestabilizar esse lugar neutro e seguro implementado e sustentado pelo poder hegemônico, resistindo a ele através de uma bricolagem, “usando inúmeras e infinitesimais metamorfoses da lei, segundo seus interesses próprios e suas próprias regras” (Certeau, 2005, p.40). 


\section{Os pequenos grandes homens}

Essas vidas, por que não ir escutá-las lá onde, por elas próprias, elas falam $?^{60}$

Dizer as imagens e as palavras - os olhos e as vozes - é a única forma de dar visibilidade à impossibilidade de sentido de certos acontecimentos. ${ }^{61}$

\section{1}

\section{O silêncio dos sujeitados}

Antes de iniciar este capítulo gostaria de esclarecer que, parte dele, foi elaborada na primeira pessoa por um simples motivo: se assim não o fizesse, me soaria como algo artificial, como se alguém estivesse falando por mim... Assim como nós, 'psis', muitas vezes falamos pelo paciente...

Ao longo de meu trajeto no MJ fui reunindo - sem objetivo definido -, imagens de alguns homens e mulheres que, por alguma razão me afetavam mais do que as imagens de alguns outros. Assim, sem muita explicação, me vi nas mãos com histórias de personagens vivas num mundo quase morto. Histórias que demonstravam um misto de amargura, desamparo, ódio, ingenuidade, desesperança, alheamento, enfim, histórias que, para muitos, seriam consideradas 'histórias de loucura'. E em algum momento do qual não consigo precisar com exatidão, comecei a perceber que aquelas imagens, despretensiosamente gravadas ao longo dos anos, poderiam servir como instrumento facilitador na tentativa de desnaturalizar o que secularmente vinha sendo instituído: a maneira de se olhar o louco-criminoso. O audiovisual poderia contribuir para a promoção de novos entendimentos e perspectivas acerca da loucura.

Como é comum na produção de documentários, nenhum roteiro foi produzido com antecedência. Tampouco me inquietei em fazer marcações preliminares, nem em elaborar perguntas pré-programadas ou locais de filmagem previamente determinados. Não houve preocupação com nenhum detalhe técnico

\footnotetext{
${ }^{60}$ A vida dos homens infames. (1977 d, p. 208).

${ }^{61}$ Corpos inabitáveis, errância, filosofia e memória, (2001, p. 251).
} 
como luz, som, ou posicionamento de câmera. Sequer houve cenário: o paciente era o cenário mesmo.

Este trabalho de captação de imagem do dia-a-dia dos pacientes do MJ começou por um desejo em travar uma comunicação informal e mais próxima com o paciente, liberando-nos, a mim e a ele, do habitual setting terapêutico. A maioria dos encontros foi gravada no pátio da instituição, no interior das enfermarias, nas saídas extramuros e alguns, por questões de preservação do próprio paciente ${ }^{62}$, foram tomados dentro da sala de atendimento. As imagens e as conversas iam sendo gravadas sem qualquer objetivo específico: apenas o de ouvir o que aqueles sujeitos tinham a dizer - ou a não dizer; suas histórias de vida, o seu cotidiano ou, simplesmente, o que quisessem falar; de que forma resistiam ou não - às imposições institucionais. Ao longo dos anos, fui guardando esses pedaços de histórias, aqui e ali, e decidi valorizar exclusivamente o testemunho daqueles que, via de regra, são sujeitos considerados como 'não confiáveis' e 'não privilegiados', ou seja, priorizei tão somente a palavra dos 'homens infames'.

Entendo que, ao falar de si, o homem cria possibilidades de resignificar não o passado, mas o presente mesmo, podendo, assim, transformá-lo, e a simples captação de suas imagens, por si só, proporcionaria a escuta e o acolhimento do sofrimento daqueles sujeitos. Assim, acredito que, ao invés de se falar pelo paciente, deveríamos dar-lhe a palavra. Por conseguinte, minha intenção foi a de criar condições para que eles pudessem falar por si próprios, ao invés de serem falados por aqueles que usualmente se apoderam de seus discursos.

Falar por si mesmo, fora do enquadre terapêutico, fora da situação ‘especialista-paciente’, possibilita ao sujeito sentir-se mais livre para deixar surgir suas outras facetas, suas histórias de vida - reais ou inventadas -, seus gostos e preferências, seus sonhos e desilusões. Pelo fato de conhecer os pacientes há muitos anos, a minha presença nas conversas facilitou o modo como eles se expressaram. Não havia interesse de em me colocar em um papel de destaque ou de liderança, nem tampouco de me posicionar de forma neutra, impessoal, ‘superior', como se fosse detentora de alguma espécie de poder. Pelo contrário, a captura das imagens se deu de maneira bastante natural, instaurando-se um modo

\footnotetext{
${ }^{62}$ Como havia livre acesso aos pacientes e, inclusive, toda a liberdade do uso da câmera dentro das dependências da instituição, não era incomum que alguns agentes de segurança se aproximassem com o intuito de se certificar sobre o quê os pacientes estavam me relatando.
} 
peculiar de discursividade entre entrevistador e entrevistado: eram, na verdade, encontros e conversas. Não havia nenhuma intenção, naquela situação, em entender os motivos que pudessem ter levado o sujeito à execução de determinado crime ou, tampouco, em tentar compreender as motivações psíquicas que o pudessem ter provocado: pretendia ouvir as histórias pessoais de cada um, e não somente o relato de seus crimes. Tampouco cogitei em captar histórias que relatassem fielmente a realidade, ou que fossem retratos precisos dela; ao contrário, interessava-me por ouvir frases ou até mesmo simples palavras portadoras de queixas, sofrimento ou mesmo de alegria; palavras raivosas, doces ou loucas. Interessava-me por ouvir histórias, a conhecer mais um pouco sobre aquelas pessoas que já faziam parte do meu cotidiano institucional; despertava-me a curiosidade por ouvir histórias de vida, simplesmente.

Em momento algum pretendi fazer ‘estudo de caso’ com aquelas histórias; naqueles encontros dialógicos eu jamais intencionei buscar o que 'realmente aconteceu', nem tampouco procurei constatar 'a verdade', ou a investigar como tudo teria começado... Outrossim, não se pretendia - como muitos acreditam que haja, nessas circunstâncias - ‘dar voz’ àqueles sujeitos. Como ‘dar voz’ a quem já as tinha? Meu intuito era apenas o de ouvir aqueles homens e mulheres em seus gestos singulares, em seus momentos de ira e de alucinação, em seus delírios, nos pensamentos perdidos, nos seus gritos e em suas risadas entristecidas. Pessoas que, expulsas da vida comum, erravam pelos pátios e corredores do MJ, invisíveis, a não ser pelas histórias de seus crimes e insanidades.

Ao compilar essas imagens pensei - caso um dia fossem mostradas - qual seria a sua serventia, em que medida elas poderiam ser úteis para a desconstrução do julgamento e dos (pré) conceitos erigidos com relação à loucura e a tudo que se coloca em seu entorno. Preocupava-me a idéia de que essas imagens pudessem produzir efeitos desastrosos, dignos talvez de pena, horror, ódio, aturdimento. Contudo, sabia também que aquelas pessoas - apesar de seus delitos e de sua doença -, tinham outras histórias a contar. Não se tratava de mostrar apenas um sujeito submetido, delirante ou sicário, mas, sim, de apresentar o mesmo sujeito no seu dia-a-dia, dentro de um mundo isolado e excluído pela lógica social, pela moral e pela racionalidade; mas ainda assim, um sujeito de 'carne e osso', com seus medos, angústias e insatisfações. Não quero, com isso, negar que a loucura 
não exista: quero apenas refletir como, ao longo dos séculos - e ainda hoje -, as sociedades objetivaram esse fenômeno chamado demência. Quero apenas mostrar que o louco, mesmo que o quisesse, não poderia ser louco durante as vinte e quatro horas do dia, ainda que algumas pessoas assim o desejassem, ainda que alguns saberes o tentassem anulá-lo, colocando-o no silêncio do isolamento e reservando-lhe o lugar da marginalização....

Mostrávamos, anteriormente, que Michel Foucault se ocupou, não em fazer uma arqueologia da psiquiatria, mas, sim, em construir uma arqueologia do silêncio dos loucos, através da reconstrução das práticas e dos saberes que determinam a percepção social da loucura. Em seu Foucault: o silêncio dos sujeitos, José Carlos Bruni demonstra como os saberes estabelecem e objetivam o louco, “o imaginário que nele se investe, o medo que dele se tem, a proteção que dele se necessita, o espaço peculiar onde é enclausurado [...], o olhar que o objetiva” (Bruni, 1989, p. 202). Por esta razão, indagamo-nos por que as instâncias médicas-jurídicas têm insistido na busca incessante em definir quem é o 'louco-criminoso'? Qual o interesse das ciências em produzirem formas de objetivação do sujeito: o doente e o sadio, o bom e o mau, o delinqüente e o correto, o louco e o são? Foucault (1995 a) analisa que o sujeito passa a ser dividido e comparado em relação a outros sujeitos; tentam-no objetivá-lo, transformá-lo de indivíduo em sujeito-sujeitado e, assim, excluem-no do 'mundo humano', como se fosse um 'não-humano'. Notamos que é a partir desse movimento de exclusão, lá onde melhor se pode sujeitar o outro, lá onde

se podem reconstituir os processos insidiosos de estigmatização, discriminação, marginalização, patologização e confinamento, operando ao nível da percepção social, do espaço social, das instituições sociais, do senso comum, do aparelho judiciário, da família, do Estado, do saber médico. De qualquer maneira o resultado é o mesmo: o silêncio dos sujeitados, silêncio que é o primeiro e mais forte componente da situação de exclusão (BRUNI, 1989, p. 201).

Sabe-se, historicamente, que o paciente encarcerado em manicômio teve a sua fala negada ou metamorfoseada ao longo dos tempos. E esse tempo parece estar longe de se findar: a lógica da produção do silêncio impera até os dias de hoje nos espaços da exclusão, seja ele o manicômio ou a penitenciária. Mas, felizmente, as brechas existem: quando uma paciente se recusa a falar de frente para a câmera, podemos entender a sua atitude como um ato de resistência. Pois 
como nos ensina Foucault, a partir do momento em que há uma relação de poder, há sempre possibilidade de resistência. Com efeito, "para resistir, é preciso que a resistência seja como o poder: tão inventiva, tão móvel, tão produtiva quanto ele. Que, como ele, venha de 'baixo' e se distribua estrategicamente” (Foucault, 1979 b, p. 241). É como se o poder estimulasse a paciente a resistir. Sem dúvida, a resistência se define nas relações de poder, isto é, não se trata de uma capacidade inata que antecede a relação: a resistência ocorre na relação mesma. Para Foucault, ela pressupõe um sujeito ativo, capaz de dizer não. Ao se recusar a falar para a câmera, a paciente se insurge contra uma norma: a norma da obediência aos 'especialistas'.

Por outro lado, ao impedir que o paciente fale, mantém-se o objetivo da mentalidade jurídico-psiquiátrica em considerá-lo como um não-sujeito. À instituição não interessa que ele possa externar os seus desejos como sujeitoagente, nem tampouco a revelar o seu rosto transfigurado pela amargura e pelo desespero. Deve-se, portanto, manter o silêncio dos sujeitados, esses habitantes sem rosto e sem voz. Sem rosto e sem voz? Enganam-se aqueles que creem nisso! Rostos e vozes existem insofismavelmente nesse universo: são, contudo, calados e dissipados. Uma vez significados como denúncia ou oposição ao poder, suas vozes são silenciadas e seus testemunhos são abafados; a memória - ainda que impregnada por invenções e delírios - é desqualificada e, via de regra, impedida de se expressar.

Conforme reflete Eugénia Vilela, "negamos a verdade àqueles a quem despossuímos da memória. Sem ela, a violência é a única possibilidade” (Vilela, 2001, p. 245). Concordando com a autora, entendemos a memória não apenas como um depositário passivo de fatos, mas tão somente como produção mesma de subjetividade; a memória é um terreno fértil de produção de sentido, expondo-se por desvios, interrupções e equívocos.

Ao falar de si e por si, o paciente passa a existir para além de um discurso legitimado pelos jogos de verdade instituídos pelos saberes da psicologia ou do direito: sua narrativa passa a ser uma construção histórica, ainda que considerada pela ciência como uma 'história vista de baixo', expressão criada pelo historiador britânico, Edward P. Thompson. Para o autor, trata-se de tornar pública a história dos personagens anônimos, subalternos, daqueles excluídos da 'história oficial'. 
Apenas os vitoriosos são lembrados. Os becos sem saída, as causas perdidas e os próprios perdedores são esquecidos. Estou tentando resgatar o pobre tecelão de malhas, o meeiro luddita, o tecelão do 'obsoleto' tear manual, o artesão utópico [...] dos imensos ares superiores de condescendência da posteridade (THOMPSON, 1992, p. 64).

Também Michel de Certeau, como vimos no capítulo anterior, harmonizase com essa idéia, fundamentando seus estudos na linguagem oral do homem comum, com suas palavras inventadas, com seus vocábulos únicos, particulares o que nos faz lembrar as criativas expressões que alguns pacientes do MJ utilizam no seu falar cotidiano ${ }^{63}$. Para Certeau (2005), os relatos orais têm um papel fundamental na produção e na recriação mesma do indivíduo. Destarte, para o autor, a prática da oralidade é um ato produtivo, fecundo e criativo, que traz em si uma diversidade de códigos e de referências singulares. Mas nem todos comungam com esta preocupação, a de ouvir o homem comum, o desconhecido, o 'diferente de nós'. Há aqueles que pretendem falar por essas chamadas minorias: a do louco, a dos perdedores, a dos 'sem lugar', acreditando que estas minorias de 'pequenos homens' necessitam do seu saber de especialista, de sua verdade dita científica para os fazerem existir. É como se esses 'pequenos homens' não pudessem falar do lugar mesmo de seus próprios saberes, de suas próprias experiências. Assim sendo, acabam por serem excluídos, conforme sugere José de Souza Martins:

Basicamente, exclusão é uma concepção [...] que nega à vitima a possibilidade de construir historicamente seu próprio destino, a partir de sua própria vivência e não a partir da vivência privilegiada de outrem. (MARTINS, 2002, p. 45).

As estratégias de saber e de poder, através do espaço institucional e do discurso jurídico-psiquiátrico, mantêm-se como o lugar e forma de produção da verdade. Assim é, e assim sempre foi a função do hospital psiquiátrico no século XIX: o lugar de classificação e diagnóstico, ou seja, o lugar de produção da verdade, espaço destinado ao confronto, à disputa entre vitória e submissão, ao jogo de domínio a ser exercido sobre o louco.

O grande médico do asilo - seja ele Leuret, Charcot ou Kraepelin - é ao mesmo tempo aquele que pode produzir a doença pelo saber que dela tem, e aquele que pode produzir a doença em sua verdade e submetê-la, na realidade, pelo poder

\footnotetext{
${ }^{63}$ Incluídas em suas histórias ao final deste capítulo.
} 
que sua vontade exerce sobre o próprio doente. Todas as técnicas ou procedimentos efetuados no asilo do século XIX [...] tinham por função fazer do personagem do médico o "mestre da loucura"; aquele que a faz se manifestar em sua verdade quando ela se esconde, quando permanece soterrada e silenciosa, e aquele que a domina, a acalma e a absorve depois de a ter sabiamente desencadeado (FOUCAULT, 1979 e, 122).

E foi assim que, justamente, pôde a linguagem da psiquiatria se estabelecer sobre o silêncio dos sujeitados (Bruni, 1989). Desta feita, constatamos que, promovendo o aparecimento dos invisíveis, a 'história vista de baixo' estabeleceu um rico diálogo com uma ferramenta utilizada como instrumento para desnaturalizar o naturalizado, para fazer falar o silêncio. Analisemos e reflitamos agora sobre essa importante ferramenta, qual seja, a História Oral.

\section{2}

\section{Passeando pela História Oral na companhia de Foucault, Portelli e Coutinho}

Em meados do século XIX, havia dois tipos de pessoas que se destacavam como autores dos livros de história: eram os profissionais liberais, mais especificamente, os advogados, e os segmentos da sociedade tradicional, como a Igreja e os representantes da nobreza. Eram essas as pessoas que dominavam os estudos históricos da época. Somente nos idos de 1870, é que o lugar da história na sociedade francesa se alterou, momento em que se tentou, através de grande esforço coletivo, romper com o antigo panorama, até então instalado. Dessa forma, as novas elites republicanas - preocupadas com a utilização política que os conservadores faziam da história -, se empenharam em assumir o controle da produção da memória coletiva do país. Assim, a História como disciplina científica, se inicia no século XIX, relacionada aos Estados Nacionais, ‘inventando tradições’ e, como campo autônomo de saber, ela tenta se distinguir do mito, da fábula, do jornalismo mesmo, das superstições.

A emergência do movimento contemporâneo da História Oral ocorreu em 1948 como uma técnica de documentação histórica, ao se começar a gravar as memórias de personalidades importantes da história norte-americana (Thompson, 1992). De acordo com Heliana Conde Rodrigues (2002), a despeito de 
experiências anteriores nas ciências sociais e da busca de precursores na Antiguidade, analistas do percurso da História Oral situam o começo do movimento no pós-guerra estadunidense - segundo um paradigma posteriormente designado como 'modelo Columbia' ou 'modelo arquivístico' -, e entendem a História Oral como uma metodologia de pesquisa surgida como forma de valorização de memórias. Como história, ela evoca uma narrativa do passado; como oral, ela indica um meio de expressão.

Segundo leciona Marieta de Moraes Ferreira (1996), a utilização do gravador com fins de coleta de depoimentos pessoais iniciou-se na década de 1940 com o jornalista Allan Nevins, que concebeu um programa de entrevistas voltado para a recuperação de informações sobre a atuação dos grupos dominantes norte-americanos. À época, o objetivo dos historiadores era colher os discursos dos 'grandes homens' - aqueles comprovadamente detentores de 'vidas significativas' - para registrar os fatos e legá-los à posteridade; o intuito era o de gerar documentos de homens públicos, herdando-os para o futuro da humanidade: a voz se torna letra, que passa a ser arquivada e destinada aos tempos vindouros...

Desse modo, a História Oral passa a privilegiar o estudo das elites e a preencher as lacunas do registro escrito através da formação de arquivos com fitas transcritas. Ou seja, ela passa a se ocupar apenas em documentar a narrativa das grandes patentes, do alto escalão; seu intuito, inicialmente, era o de controlar as vozes da minoria. Ainda, segundo Ferreira (1996), o começo oficial da História Oral contemporânea no Brasil foi, aparentemente, marcado pelo mesmo modelo: o de uma 'história das elites' a ser arquivada sob o ‘modelo Columbia'. Tratava-se de uma história oral onde as minorias eram negadas, onde se pretendia fazê-las calar, ao invés de fazê-las falar. Era necessário apaziguar todo e qualquer murmúrio ou alvoroço. Aqui, acompanhando Foucault, indagaríamos porque o aleatório teria que ser tão ordenado, “o que há, enfim, de tão perigoso no fato de as pessoas falarem e de seus discursos proliferarem indefinidamente?” (Foucault, 1996, p. 8).

Em boa hora surge principalmente na Itália, uma nova geração de oralistas preocupada agora em ouvir a 'voz das minorias', dos soldados rasos, dos 'pequenos homens', ou se quisermos seguir Foucault, dos 'homens infames', onde o adjetivo remete a 'sem fama', e não a qualquer condenação moral, mas tão 
somente àqueles sem importância, sem glória. Esta nova maneira de historiografar - conferindo existência ao invisível -, tenta resgatar a história de extratos sociais que não possuíam registros oficiais, contrapondo-se aos métodos da chamada 'história tradicional' que, segundo Burke (1992), preocupou-se sempre com uma história nacional, e não com a regional. Mas a nova historiografia, que teve lugar ao final dos anos 60 e início dos anos 70, principalmente nos Estados Unidos, promoveu uma reviravolta nos estudos históricos, voltando-se para o estudo da cultura, da vida cotidiana, da vida privada, das crenças e das relações de poder nos mais diversos campos sociais. Ela afasta-se dos grandes paradigmas explicativos das ciências, passando a se preocupar agora com as interrogações do presente e a se interessar pelos aspectos simbólicos e culturais da sociedade. As lutas travadas pelas minorias de negros, mulheres, e outros grupos sociais, seriam agora as principais responsáveis pela afirmação da história oral, que se afirmava como instrumento de construção de identidade, tirando do esquecimento o que a história tradicional havia silenciado através da voz dos 'grandes homens'.

Esta 'nova história', que inicialmente priorizava a objetividade na recuperação das memórias e das fontes orais viu-se, nas últimas décadas, implicada com a valorização da experiência vivida e com a subjetividade do narrador mesmo. Empenhando-se pela 'história das minorias' cria, assim, um novo campo para a pesquisa histórica que valoriza as trajetórias de vida e os depoimentos pessoais. O indivíduo, que havia sido banido da narrativa historiográfica - em detrimento às grandes massas como sujeitos da História -, retorna como sujeito em relação com outros sujeitos, construindo trajetórias de vida nas quais a história de um grupo poderia ser lida através de múltiplas histórias de vida (Araujo \& Fernandes, 2006). Portanto, é lícito considerar a História Oral como uma metodologia que trata da subjetividade, da memória e do discurso.

Em seu texto, A Filosofia e os Fatos, Alessandro Portelli, renomado oralista italiano, trata da subjetividade presente nas narrativas orais e aponta para a importância que lhe deve ser dada:

Se formos capazes, a subjetividade [...] será a maior riqueza, a maior contribuição cognitiva que chega a nós das memórias e das fontes orais. [...] não temos a certeza do fato, mas apenas a certeza do texto: o que nossas fontes dizem pode 
não haver sucedido verdadeiramente, mas está contado de modo verdadeiro (PORTELLI, 1996, p. 61).

Para ele, mais relevante do que a objetividade do fato, é a forma como o sujeito o vivencia e o interpreta. A maneira como os entrevistados contam a história é, na realidade, o objeto de estudo da oralidade. A valorização da subjetividade na experiência histórica é uma das mais ricas contribuições da História Oral. O autor não nega a objetividade dos fatos, mas, assim como aprendeu que nunca deveria desligar o gravador durante as entrevistas ${ }^{64}$, também ele nos ensina a ficar de coração e ouvidos bem abertos aos detours que atravessam a história.

Assim como Portelli, Foucault também constata que não é apenas a história que interessa ao pesquisador, mas, sobretudo, aquilo que escapa a ela. Deste modo podemos observar a existência de uma forte relação entre a prática da história oral de Portelli e o pensamento foucaultiano. Acrescentaríamos a este contexto mais um autor, agora no campo do audiovisual, que nos indica incluir o que há de contingente na história: trata-se do brilhante cineasta e documentarista Eduardo Coutinho, cuja filmografia demonstra uma estreita relação aos dois primeiros autores naquilo que eles problematizam em comum, qual seja: a subjetividade como produção, a verdade enquanto circunstanciada e contingente, a memória como um processo ativo de ressignificações, e a história formada por encontros fortuitos: uma história mutável, que rompe com o presente e o desestabiliza. Segundo o diretor, ao contrário do que muitos pensam, o documentário não é a filmagem da verdade: “[...] é antes, o que revela a verdade da filmagem, o momento em que ela acontece, com todo o seu aleatório, na sua contingência” (Coutinho, 1997, p. 167). Dito de outra maneira, para Coutinho, o cinema-documentário não filma a verdade, mas ele é, tão somente, a verdade da filmagem até onde pode ser, pois esta é a forma mais rica do que a pretensa filmagem da verdade. É nela - na verdade da filmagem - que se registra o inesperado, o imprevisto, a recusa.

Ao invés de interessar-se pela história dos 'grandes homens'- como no caso da história tradicional -, a nova história se ocupa das massas anônimas e dos

\footnotetext{
${ }^{64}$ Portelli (1997a) aprendeu esta despretensiosa, mas importantíssima lição de Gianni Bosio etnólogo e historiador italiano: "Nunca desligue o gravador, isto é, nunca deixe de prestar atenção e sempre demonstre respeito pelo o que as pessoas escolhem dizer a você”.
} 
documentos 'não intencionais' oferecendo, como já foi dito, uma 'história vista de baixo’. Muitas vezes, a única forma de se chegar a esses personagens anônimos é através das fontes orais que, na visão de Alessandro Portelli, são condição necessária para a história das classes não hegemônicas, e menos necessárias para a história das classes dominantes, pois estas "têm tido controle sobre a escrita, e deixaram atrás de si um registro escrito muito mais abundante” (Portelli, 1997 a, p. 37).

Apesar das transformações produzidas com o surgimento da nova história, parece que foi através da obra de Foucault que, de fato, se deu a maior transformação no campo da história como um todo. Paul Veyne (1990) interpreta a sua obra como o marco de uma transformação fundamental no pensamento histórico. Para ele, a 'revolução foucaultiana' consistiu na modificação de uma perspectiva de análise focada em ‘objetos’, para uma outra, focada em ‘práticas’.

Dito de outra maneira, é preciso desviar os olhos dos objetos naturais para perceber uma certa prática, muito bem datada, que os objetivou sob um aspecto datado como ela; pois é por isso que existe o que chamei anteriormente, usando uma expressão popular, de 'parte oculta do iceberg': porque esquecemos a prática para não mais ver senão os objetos que a reificam a nosso olhos (VEYNE, 1990, p. 243).

Para Foucault, não existem coisas, só existem práticas. A loucura não existe como objeto, a não ser mediante uma prática: a prática do internamento. É ele quem adverte que "é o hospício que produz o louco como doente mental" (Machado, 1979, p. XIX). Em outras palavras, poderíamos afirmar que não existe nada que seja natural, nativo, originário, mas tão somente aquilo enquanto construído. A loucura não pode ser tomada como objeto natural, como algo que ‘já lá estivesse’. Na verdade, é a emergência do encarceramento, é a sua prática e são os seus discursos que sustentam e reforçam o que se denomina de loucura. Daí a atenção foucaultiana dispensada àquilo que é dito, e não a quem o disse; importa-lhe como e não quem.

Assim como os laudos e exames utilizados pelas instâncias jurídicopsiquiátricas, observamos uma semelhança com relação aos pressupostos da História Tradicional, no que diz respeito à busca da verdade e ao passado tal como ele ocorreu. Neles, é possível observar-se algo bem distinto do que propõem Foucault e Coutinho; tais procedimentos jurídicos buscam na fala do acusado, a 
verdade absoluta, o relato coerente, o nexo causal, a objetividade do fato, tentando desta forma, reconstituir detalhadamente o passado e assim, chegar-se à verdade. Trata-se de uma abordagem historicista, onde o estudo do passado pressupõe uma origem como forma primeira. Nela, considera-se o passado como aquilo que marca o presente, cristalizando-o. Assim, não restaria mais nada ao sujeito a não ser cumprir com o seu destino: uma vez louco/criminoso/anormal, para sempre, louco/criminoso/anormal. Parece, portanto, tratar-se de uma perspectiva que se utiliza do passado para justificar o presente, e mais - como em uma cadeia associativa -, determinar o futuro.

Foucault critica esse historicismo, não no sentido de negar a história, mas no sentido de recusar o conceito de história atrelado à idéia de origem, à idéia de uma verdade única e primeira. Na sua concepção, a história não tem por objetivo revelar a origem de nossa identidade, mas ao contrário, “se obstinar em dissipá-la, [...] fazer aparecer todas as descontinuidades que nos atravessam” (Foucault, 1979 d, p. 35). Para o autor, problematizar o presente é o que leva a romper com o curso da história. É clara a sua oposição em relação à idéia da existência de uma verdade absoluta, estabilizadora, inquestionável. Em contrapartida, propõe verdades parciais, não definitivas, passíveis de transformação. Verdades, que se deslocam dos pontos de solda, formando novas costuras, novas verdades. Sem dúvida, Michel Foucault pensa a história em termos de descontinuidade, de rupturas, de singularidade, com temporalidades distintas, utilizando-se da história para romper com o presente, para desnaturalizá-lo. Segundo advertem Araújo e Fernandes,

[...] o fator singular presente no depoimento oral é que a fonte é constituída por uma narrativa e que esta consiste na interpretação da experiência vivida, longe da objetividade e da verdade almejada pela historiografia tradicional [...] o papel do historiador é justamente tentar 'desnaturalizar' as construções da memória oficial (ARAÚJO e FERNANDES, 2006, p. 23).

Ao se falar em memória oficial ${ }^{65}$, lembramos Portelli que, ao longo de suas pesquisas, optou pelas histórias construídas pelos 'pequenos homens', ao invés de se apoiar na historicização da memória oficial das 'grandes elites'. Para ele, “a

\footnotetext{
${ }^{65}$ Segundo Michael Pollak (1989), a memória oficial, geralmente construída intencionalmente, pode disputar espaço com as chamadas 'memórias subalternas', onde o silêncio aparece como uma estratégia de sobrevivência.
} 
história oral nos conta menos sobre eventos do que sobre significados. [...] entrevistas revelam eventos desconhecidos [...] que sempre lançam luz sobre áreas inexploradas da vida diária das classes não hegemônicas” (Portelli, 1997 a p. 31). E é destas classes não hegemônicas que a História Oral pretende falar. Ela se propõe a problematizar este social, insistindo em alguns pontos nevrálgicos que se mantêm invisíveis, escondidos e geralmente incômodos.

Da mesma forma pensamos que assim deva ser o papel do profissional 'psi’ operando no interior das instituições, qual seja, o de tentar desnaturalizar as construções da memória oficial, o de apontar para os 'não-ditos', o de recusar a responder sempre prontamente 'porque sempre foi assim'; ao invés disso, ele deverá buscar revelar as redes de poder, os jogos de verdade, os processos de ocultação dos acontecimentos, trazendo à tona a vivência pessoal e a subjetividade de cada paciente para enfim, evidenciar o relato desses 'pequenos grandes homens'.

Daisy Perelmutter (2006) reforça esta idéia, afirmando que “[...] o que a história oral nos parece trazer de forma caudalosa são as representações da experiência vivida, o sentido atribuído ao passado pelos próprios sujeitos que o protagonizaram". Vemos assim que, o que importa é a maneira como os entrevistados vão contar a história: os enganos ou as fantasias transformam-se em detalhes riquíssimos de investigação. O mesmo ocorre com os delírios e alucinações que compõem, por vezes, o relato de alguns pacientes do MJ. Ouvir o outro é, não só ouvi-lo e valorizá-lo em suas palavras, mas é também se responsabilizar pelo vínculo formado neste encontro:

É evidente que eu me sinto responsável por aquela favela, por aquelas pessoas do lixo que eu filmei. Obviamente se é uma imagem decente que eu transmito deles, eu suponho que vou ser fiel a uma relação com os favelados em geral, com as pessoas do lixo em geral, etc., mas o importante são aquelas pessoas que tem nome; não é uma confiança de classe desencarnada, é encarnada em pessoas que foram gentis comigo (COUTINHO, 1997, p. 170).

Reconhecer o outro, portanto, possibilita ao sujeito se apossar de sua própria história contribuindo, ele mesmo, para a formação de novas subjetividades. Assim como Coutinho, temos outros autores que costumam ouvir as histórias dos 'pequenos homens'. Em seu documentário, Notícias de uma guerra particular, João Moreira Salles não mostra a polícia nem o 'dono do 
morro', mas a história comum dos moradores, dos 'sem história', dos 'homens infames'. Assim como o rapper MVBill, que ouviu os invisíveis 'falcões’ do tráfico, ao invés dos 'grandes traficantes'.

Foi através dos recursos audiovisuais - da fotografia e da filmagem - que começamos a perceber o quanto eles poderiam contribuir para libertar o sujeito do destino que já lhes havia sido traçado. Sem dúvida, podendo narrar a sua própria história, o paciente encontra-se mais disponível a fazer novas movimentações e prováveis mudanças: a palavra possibilita-o a apropriar-se de sua vida mesma. A câmera torna-se, assim, a prova daquilo que não pode ser dito nem visto. A partir dela, é possível passar-se a palavra ao louco - mas não à loucura como uma entidade genérica, que fique bem claro. Não nos interessa uma narrativa histórica geral que fale sobre a loucura, mas tão somente nos interessa ouvir a palavra de sujeitos singulares, de identidades nomeáveis, marcadas nos seus corpos e nas suas almas. Como nos ensina Eugénia Vilela:

no testemunho, aquele que se manifesta passa a existir para além de um discurso legitimado pelos jogos de verdade [...] pois adquire, por um lado, uma dignidade decorrente da sua condição de homem-memória e, por outro, uma legitimidade e identidade sociais enquanto portador de história. [...] Dar sentido através dos nomes aos acontecimentos sem memória é não dizer o outro, mas erguer a voz do outro, é construir linguagens de resistência (VILELA, 2001, p. 245- 248).

Dito de outra maneira, o ato de testemunhar, de falar com sua própria voz, desafia os jogos legitimados pelos diferentes regimes de poder/saber, afirmandose como um ato mesmo de resistência. Resistência que cria condições de possibilidade de produção de novos sentidos, de novos significados, de novas linguagens, e não apenas aquela produzida pelo especialista ou mesmo pelo conhecimento científico.

Ao passar a palavra a esses sujeitos, temos apenas uma certeza: a de não se falar por eles, mas sim, a de oferecer acesso para que suas histórias individuais possam se destacar sobre aquilo a que foram previamente destinadas. Não é incomum que esses sujeitos sejam 'falados' através da voz do profissional 'psi', tanto através de laudos, como de pareceres, ou ainda na prática mesma de suas relações. O louco, o delinquente, o demente, o inimputável, o encarcerado, passa a ter nenhuma importância; ele sequer é ouvido. Fala-se por ele. Mas, se por acaso, vier a tomar a palavra, isto poderá significar o grande risco dele ser punido. 
Podemos observar esse fenômeno quando, ao definir o que é o MJ a partir de sua própria experiência vivida lá dentro Anderson fala com a sua própria voz ${ }^{66}$. Contudo, sob outras circunstâncias, a sua palavra poderia ser vista como algo perigoso e, justamente por não possuir crédito algum, o que o paciente dissesse poderia ser entendido da forma que melhor aprouvesse à instituição. Neste caso, a saída tradicional é, presumindo-se ali um sujeito louco e intrinsecamente perigoso, segregá-lo ao silêncio da tranca.

Sabe-se que, ao longo dos séculos, a instituição vem se manifestando como uma grande expert em calar ou em distorcer a voz do sujeito asilado. Dificilmente ouvimos relatos provindos dos próprios pacientes quanto ao método de internação a que são submetidos, quanto às formas de tratamento que lhe são impostas, e quanto aos seus direitos e deveres a serem cumpridos durante o período de cumprimento da medida de segurança. Fala-se sobre a loucura, sobre a delinquência, sobre o manicômio, sobre a prisão, fala-se... Mas não se ouve a voz daqueles que lá habitam.

Acreditamos na importância da participação do indivíduo no processo de mudança, no seu reconhecimento como autor e transformador de sua própria história. Conhecendo a sua realidade, ele tem acesso a uma identidade social, que o faz saber quem ele é e aonde quer chegar. Quando se impede o sujeito de participar da sua realidade, está-se negando a sua existência como ser humano. José de Souza Martins (2002) denuncia o desencontro entre a forma como esses indivíduos e seus infortúnios se situam dentro da sociedade, e a maneira como os profissionais acadêmicos ou os de campo a percebem, isto é, de fora para dentro. Com frequência trazem prontas as suas teorias, tentando encaixá-las em conceitos pré-estabelecidos, procurando falar pela voz do outro, negando ao sujeito mesmo a possibilidade de construir historicamente seu próprio destino, a partir de sua própria história.

Ao serem descritos e analisados através dos procedimentos psico-jurídicos, os pacientes são falados através da voz do pesquisador, que passa a ser o detentor da verdade sobre a história daqueles sujeitos. Mais uma vez podemos traçar um paralelo com a idéia de Foucault a respeito da verdade e do poder. Em conversa

\footnotetext{
${ }^{66}$ Estamos nos referindo ao seu comentário sobre se o MJ seria um hospital ou uma prisão.
} 
com Gilles Deleuze no capítulo intitulado Os intelectuais e o poder (1972 b), ele argumenta:

Os intelectuais descobriram recentemente que as massas não necessitam deles para saber; elas sabem perfeitamente, claramente, muito melhor do que eles; e elas o dizem muito bem. Mas existe um sistema de poder que barra, proíbe, invalida esse discurso e esse saber. [...] quando os prisioneiros começaram a falar, viu-se que eles tinham uma teoria da prisão, da penalidade, da justiça. Esta espécie de discurso contra o poder, esse contra-discurso expresso pelos prisioneiros, ou por aqueles que são chamados de delinqüentes, é o que é fundamental, e não uma teoria sobre a delinqüência (FOUCAULT, 1979 b, 71 72).

E complementando, Deleuze dirige-se a Foucault: “A meu ver, você foi o primeiro a nos ensinar - tanto em seus livros quanto no domínio da prática - algo de fundamental: a indignidade de falar pelos outros” (Foucault, 1979 b, p. 72).

Mais uma vez, em seu belo artigo, Foucault: o silêncio dos sujeitos, José Carlos Bruni (1989) ratifica a posição de Foucault com relação ao tema, afirmando que ele não pretendia 'dar voz à loucura' nem tampouco tinha a intenção de ser o seu porta-voz. Constatamos a mesma preocupação sobre a 'indignidade de se falar pelo outro' em artigo de Walter Salles sobre um comentário de Alberto Granado, companheiro de Che Guevara, protagonizado no filme Diários de motocicleta, ao perceber que o ator Gael Garcia encontrava-se muito ansioso em ter que representar Guevara com exatidão:

Não quero me intrometer no filme, mas, se você me permite uma observação, não tente mimetizar Ernesto. Você tem a mesma idade que ele tinha quando fizemos a viagem, é igualmente inteligente e sensível, está lendo os mesmos livros que ele lia. Encontre a sua própria voz para viver esta história, e assim, você fará justiça a ele (SALLES, 2011 Grifo nosso).

Da mesma forma, quando ouvimos Anderson, fica evidente - a despeito de seu estado delirante - que ele fala de um lugar que é mesmo seu: ninguém o representa; ele o faz por si mesmo. Isto nos remete, com pesar, a atitudes tomadas por alguns intelectuais que tentam se apropriar de histórias e experiências de vida, tanto de grupos quanto de movimentos culturais, travestindo as suas singularidades em discursos sociológicos, psicológicos e afins. Não é incomum assistirmos o contar-se a história da escravidão sem ter se ouvido o escravo; ou de se discutir a favela sem ouvir-se o favelado; ou ainda de se problematizar as 
questões da loucura sem se ouvir o louco. Os exemplos de atitudes distintas a essas são inúmeros.

Acreditamos que, ao poder falar de si mesmo, ao invés de ser falado através do outro, isso permite ao sujeito apoderar-se daquilo que é mesmo seu. A história da loucura nos mostra a herança que a psiquiatria, e até mesmo a psicologia, nos legou com seus preceitos e classificações em relação ao loucoinfrator e a todas as modalidades consideradas 'fora da ordem'. É comum observar-se o prisioneiro sendo falado através do poder jurídico; o louco sendo representado através do poder psiquiátrico; o negro através do branco; a criança através do adulto.

Segundo pensamos, ouvir o que esses pacientes têm a nos dizer, pode ser um caminho para se chegar a esses 'pequenos homens', às suas 'memórias subalternas', fazendo-as aflorar através de suas ricas e - ainda que para muitos -, estranhas histórias.

\section{3}

\section{Com a palavra, o louco!}

Conforme discutíamos no subcapítulo anterior, ao falar com sua própria voz o paciente desafia os jogos validados pelo conhecimento científico que, via de regra, o fazem calar, impedindo-o de criar novos significados para a sua própria história de vida presente. Ao ser interrogado pelos 'especialistas' - sejam eles, psicólogos, psiquiatras, assistentes sociais ou mesmo, peritos forense -, o que estes priorizam é, particularmente, aquilo que diz respeito à história mesma do crime e à doença daquele sujeito. Ou seja, supõe-se estar diante de alguém que, não só cometeu um delito como também de alguém que apresenta uma determinada patologia psíquica. Dito de outra maneira, o saber científico encontra-se pronto para evocar a figura do 'louco-criminoso'. Uma vez categorizado como tal, este só poderá responder como tal: louco, criminoso e, portanto perigoso!

Sobrar-lhe-ia espaço para deixar surgir suas outras facetas? Reservar-selhe-iam chances para atuar de novas e diferentes formas daquela que lhe foi atribuída? Pensamos que não! Diante da realidade apresentada no panorama 
médico-jurídico-institucional, podemos detectar uma forte tendência dos 'especialistas' em olhar para o sujeito inimputável como aquele que possui tão somente uma história de vida passada que, na melhor das hipóteses, confirma a sua história de vida presente; quanto à vida futura, nada lhe é guardado, a não ser se esperar que ele repita os mesmos erros, um dia, já cometidos.

Ocorre que esses mesmos sujeitos, nosologizados como louco-criminosos, têm, certamente, outras histórias a contar: não só as histórias do passado como, também, histórias de vida presente e alguns planos para o futuro - ainda que fantasiosos ou mesmo delirantes.

Por questões éticas e de preservação dessas pessoas, as informações a respeito das mesmas serão breves e ligeiramente modificadas; seus nomes serão, a partir de agora, fictícios, mas não as suas narrativas...

Reproduzindo falas autorizadas por eles próprios, passo-lhes, agora, a palavra!

História Um: Toledo tem 37 anos, é solteiro e mora com a mãe. Sobre o seu delito, ele relata, sem demonstrar nenhuma emoção:

“Um dia, passeava eu no carro de um amigo quando minha atenção foi despertada para uma moça simpática que me concedeu o regozijo de aliciar-me namorado dela, só por aquele dia... Saímos juntos pra curtir e ficamos muito embriagados. Subimos para o alto da Av. Niemeyer e namorávamos na pedra quando ela se desvencilhou de mim e caiu no precipício. Ela caiu, e eu fui embora. Não podia prestar socorro porque era um abismo”.

Diagnosticado como esquizofrênico paranoide, ele foi encaminhado ao MJ para cumprir medida de segurança, há cerca de 14 anos atrás. Toledo mostra-se não responsabilizado pelo ato cometido, como se dele não participasse, colocando-se de fora da situação ocorrida.

O paciente passa o seu tempo lendo jornais antigos e a lista telefônica. Mas a sua principal atividade e preocupação, àquela época, era a de se comunicar com a ex- primeira ministra da Inglaterra, para onde ele pretendia se mudar:

“Ela é uma pessoa encantadora! Já lhe escrevi várias cartas, mas não fui correspondido nas tais epístolas e bulas. Mas se me for cabível, gostaria que ela me concedesse a honra de ser general de seu exército. Se for atendido nesse júbilo, chegarei então a imperador! Mas se ela me intitular como condesso, já é 
um bom início... Mas falando veridicamente, minha objetivação é ser general de seu exército. Só estou aguardando ela vir me buscar. Adentrarei o país dela como arqueólogo... Estou terminando de escrever uma carta pra ela, perguntando se ela aceita ser minha fiduciária. A senhora quer ouvir?”

Por outro lado, Toledo também demonstra um aguçado juízo crítico ao tecer o seguinte comentário sobre o seu trabalho como nosso ‘secretário':

“Dra. Elza, a senhora me estressa porque faz tempestade em copo d’água, assim, à toa... Eu acabei embaralhando os nomes dos pacientes todos... não sei nem mais quem eu tenho que chamar na galeria! A senhora apronta esse sanhaço todo e eu é que me enrolo! Afinal, quem é maluco aqui, eu ou a senhora?... Ao invés da senhora me preparar, a senhora tá me despreparando psicologicamente! A senhora me estressa! A senhora é uma anti-manicomial!”

Mais uma vez notamos que Toledo, assim como qualquer outro paciente internado no MJ, não atua e nem se comporta sob a aura da loucura durante as vinte e quatro horas do dia... A partir da convivência com nossos pacientes ao longo de todos esses anos, podemos afirmar que, assim como eles apresentam aqui e ali -pensamentos e atitudes delirantes, do mesmo modo eles se mostram pessoas lúcidas, de afiado espírito crítico e de muita perspicácia.

História Dois: Anderson tem 47 anos e encontra-se internado no MJ há mais de 28 anos. Jamais recebeu sequer uma visita de seus familiares. Seu pai, considerado um 'coronel' pela família e conhecido por todos na cidade onde morava, vivia para administrar seu grande comércio. Anderson e o pai nunca se deram bem. Conta-se que, durante uma briga, assassinou a própria mulher - mãe de Anderson - quando este tinha apenas nove anos de idade, motivo da revolta que o paciente nutria pelo pai. Ninguém da família ousava enfrentá-lo, com exceção de Anderson, que o desafiava, reagindo à suas ofensas com novos insultos. Considerado um homem bastante agressivo, especialmente com suas mulheres diz-se que tinha várias -, o pai de Anderson nunca o quis por perto: acusava-o de irresponsável, de ‘drogado’ e afirmou que, certa vez, ele havia assaltado uma de suas lojas. A cada investida do pai, Anderson reagia com veemência. Como não conseguia contê-lo, mandou que o trancassem em um quarto com grades, numa espécie de jaula de onde, transcorrido algum tempo, ele fugiu para Brasília e, de lá, para o Rio. Ninguém sabe, ao certo, como Anderson aqui chegou, mas ele 
afirma, com convicção: “Minha loucura não me ajuda a raciocinar, mas sei que cheguei aqui vindo pelo rio Delta... lá onde meu avô é o homem mais rico do lugar.”

Consta de seus prontuários que ele foi acusado dos delitos de agressão, uso de drogas e roubo de carro. É fã incondicional das principais lendárias figuras do rock, paramentando-se com panos e fitas amarradas na cabeça, nos braços e nas pernas.

Durante uma de suas idas à nossa sala, como era de seu costume, sentou-se calmamente em uma velha cadeira, cruzou as finas e longas pernas, passou as mãos pelos cabelos tingidos, olhou-nos bem nos olhos e falou:

“Eu não sei se esse lugar aqui é um hospital ou uma prisão”...

Exatamente em seguida, como se estivesse prosseguindo com o mesmo assunto e de maneira plenamente natural, retrucou:

“Eu sou agente $n^{o} 1$ da Polícia Federal. Sou treinado em Brasília. Eles viram o meu cabelo, mas não notaram que eu era louco; quando eu amarrei o cabelo assim, eles viram que eu era perturbado... Eu sou um Sebastian Bach perdido e fracassado, diferente daquele lá do Canadá”...

História Três: Celso tem 46 anos e encontra-se internado no MJ há pouco mais de 19 anos sob o diagnóstico de esquizofrenia paranoide, não tendo apresentado, durante todo este período, qualquer episódio psiquiátrico. Com cerca de vinte e cinco anos, durante um de seus inúmeros surtos, Celso assassinou violentamente o pai que, segundo ele, lhe agredia fisicamente, assim como à sua mãe. Antes do delito, foi várias vezes internado em diferentes clinicas psiquiátricas. Sua família resume-se a ele e ao irmão. Pretende sair do MJ o quanto antes e quer terminar os seus estudos à noite. $\mathrm{O}$ paciente tem licença judicial para ir quinzenalmente à sua casa. Sobre o delito, ele comenta pesaroso:

“Eu não poderia ter cometido um delito como esse. Eu não cometeria isso nunca! Isso não se faz... Eu tenho que tomar minha medicação constantemente... isso aconteceu porque eu deixei de tomar os remédios... se eu sentir que isso vai acontecer de novo - mas eu sei que não vai! - aí eu mesmo chamo a polícia pra me trazer de volta pra cá... Eu tô indo no Engenho de Dentro pra fazer a praxiterapia. Lá eu conheci umas pessoas que eu fiquei amigo... A gente conversa muito... Eu quero voltar pros estudos...” 
Em certa ocasião fui à casa de Celso com ele, dirigindo o meu próprio carro; seu irmão nos aguardava. Era uma casa muito simples, de dois andares, na parte de baixo de uma das maiores favelas do Rio de Janeiro. Conversamos os três durante um bom tempo, quando Celso perguntou-me se eu não gostaria de ver o local onde havia ocorrido o delito. Subimos ao andar de cima e o paciente relatou calmamente, através de gestos, de que maneira havia assassinado o próprio pai. Com o mesmo tom de voz monocórdico e com a mesma quietação, Celso perguntou se já não era hora de irmos embora. Despedimo-nos de seu irmão e nos encaminhamos para um pequeno bar próximo à sua casa; sentamos para um rápido lanche. Por fim, pegamos o carro e retornamos ao MJ. Sentado no banco ao meu lado, Celso olhou-me sério e disse:

"Dra. Elza, a senhora precisa ter mais calma no volante... tá muito afobada... a senhora pisa muito fundo nesse acelerador!"....

Pensamos que, assim como grande parte da história de alguns povos que só puderam ser conhecidas a partir de suas canções populares ou de outras formas alternativas de comunicação - à margem dos documentos oficiais -, também as histórias dos pacientes encarcerados possam ser mais facilmente conhecidas quando realmente acreditamos que eles têm o que dizer e, assim, passamos a ouvilos, conhecendo alguns dos silêncios da história oficial, interessando-se para além dos enredos do crime e da doença. É justo afirmar que não se trata, absolutamente, de pessoas que não sabem o que dizem, ou que não tenham o que dizer; trata-se, sim, de sujeitos a quem não lhes é conferida a palavra; trata-se de sujeitos que não têm quem lhes ouça e, por isso mesmo, nada digam, exatamente por saberem que não serão ouvidos.

Consequentemente quando nos propomos a fazê-lo, deparamo-nos com histórias - reais ou fantasiosas - que podem vir a nos surpreender, nos assustar, ou até mesmo, a nos repelir, mas, sem dúvida, histórias que veem, também, nos afetar e nos sensibilizar pelo sofrimento de suas personagens. 


\section{Considerações finais}

Não se pode negar que algumas pessoas - vinculadas ou não ao mundo 'psi' -, sintam-se bastante desconfortáveis e incomodadas ao tentar ultrapassar os portões de ferro batido do MJ. Isto talvez aconteça, principalmente, pelo fato delas desconhecerem o que lhes reserva para além daqueles portões, só lhes restando, assim, serem conduzidas pelo preconceito e pela crença na equação determinista 'crime = loucura' e, por fim, sentirem-se escoltadas pelo medo do estranho, do inusitado, do obscuro, medo por aquilo que se supõe não conhecer e de, por conseguinte, não poder controlar.

Na verdade, o que não sabemos ou sabemos muito pouco, é sobre o sofrimento das pessoas ali encarceradas e diagnosticadas como loucas: é preciso deixar que elas mesmas nos falem o que sabem sobre o seu sofrimento. De fato, esses pacientes cometeram um crime, contudo crime ocorrido como efeito de um transtorno mental, ainda que possam parecer delitos hediondos ou até mesmo inexplicáveis aos nossos olhos. É preciso não se esquecer que, antes mesmo do ato criminoso, existe uma longa trajetória de sofrimento mental que, muitas vezes, resulta em transgressão como consequência da perturbação psíquica manifestada.

Procuramos mostrar que, ainda que portadores de algum tipo de transtorno, ainda que confinados e controlados pelos mecanismos da engrenagem institucional, ainda que tutelados, esses sujeitos - se puderem ser ouvidos - muito têm a dizer. E, muitas vezes, eles falam o que nós não queremos ouvir. Estes pacientes encarcerados nos nosocômios são capazes de resistir ao que lhes é imposto e determinado; eles se mostram, muitas vezes, aptos - ainda que considerados inaptos perante a lei - a dizer não às formas de dominação e de submissão: é como se a força da resistência fizesse com que as suas vozes não se calassem. Essas pessoas classificadas como inimputáveis - diferentemente daquelas consideradas 'sadias' -, são capazes de falar com suas próprias palavras e gestos, não obstante estes nos possam parecer inadequados ou ininteligíveis.

Ora, por que nos ocorre sempre pensar que a generalidade, o irrefutável, o evidente, o universal, são o termômetro mesmo da lucidez, da normalidade, da 
segurança da sociedade como um todo? Por que, ao contrário, não podemos apostar nas diferenças, nas singularidades, ainda que se apresentem excêntricas ou estranhas? Por que conter e aprisionar aquilo que se apresenta distinto de nós? Por que afastar o desigual, o bizarro, o inusitado? Recorremos a Michel Foucault, em mais uma de suas ricas contribuições:

Ali onde se estaria bastante tentado a se referir a uma constante histórica, ou a um traço antropológico imediato, ou ainda a uma evidência se impondo da mesma maneira para todos, trata-se de fazer surgir uma "singularidade". Mostrar que não era "tão necessário assim"; não era tão evidente que os loucos fossem reconhecidos como doentes mentais; não era tão evidente que a única coisa a fazer com um delinquente fosse interná-lo (FOUCAULT, 2010 e, p. 339).

Evidências, naturalizações, verdades absolutas: faz-se imperioso resistir a elas! Necessário é que, nem só os pacientes resistam, mas também nós - os operadores da saúde - possamos nos transformar no embate com as circunstâncias, resistir às injunções que nos são aplicadas e prescritas e, por fim, sermos capazes de acatar novas formas de subjetivação. Necessário é - através de uma perspectiva crítica em relação às normatizações do poder instituído -, desconstruir a lógica institucional, produzindo novos acontecimentos, novos olhares, novas posturas, enfim, desconstruindo a doutrina do 'sempre foi assim' ....

É de conhecimento de todos que qualquer sociedade surge a partir das forças que resistiram ao poder estabelecido: este se mobiliza, ora para capturar, ora para normatizar o que resiste. Mas, na verdade, o que move a história é a resistência, e não o poder. Assim sendo, acreditamos que a resistência é a mola propulsora para toda e qualquer mudança. Ela é a potência que se insurge sobre as tentativas de dominação que partem do instituído.

Ao longo do trabalho, nos foi possível constatar que tanto o paciente quanto o profissional 'psi' são sujeitos capazes de resistir. A ele, profissional, cabe perceber as tentativas de resistência travadas pelos pacientes, não como transgressão à norma instituída, mas sim, como trajeto de seu desejo, como uma atitude crítica em direção a práticas de liberdade, como uma vontade mesmo de viver. Quanto a nós, que possamos nos definir a nós mesmos, independentemente de funções ou de papéis, mas segundo uma prática de si sobre si, através da qual possamos nos transformar e atingir um certo modo de ser, não remetido a uma essência, mas como uma prática de liberdade, com um espírito permanentemente 
crítico, resistindo sempre! Assim como nos ensina a filósofa portuguesa Eugénia Vilela, quando afirma que "a resistência é uma ética dos que estão vivos” (Vilela, 2001, p. 25).

Mas, indagaríamos, em que medida essa prática da resistência se produziria?

Acreditamos que, primeiramente, há de se estranhar e se recusar o que é proposto pelo saber como sendo de validade universal - não como se o saber nada fosse -, mas interrogando sobre que condições e através de que regras esse saber reconhece e determina o sujeito como alienado ou delinquente. Faz-se mister procurar entender como e em que medida o louco foi transformado em doente mental, e quais as condições de possibilidade que o conduziram a essa categoria. Cumpre lembrar o compromisso e a incumbência do profissional 'psi' em problematizar essas questões, muito bem lembradas pelo pontual comentário de Jurandir Freire Costa:

A ética da psiquiatria termina onde começa a pobreza e o asilo. Nós temos responsabilidade, em particular a comunidade dita científica, aquele que de direito e de fato se ocupa de cuidar dessas pessoas. [...] Nós formamos esse grupo de pessoas a quem a sociedade em geral e o Estado, delegam o poder de tutelar, de tratar, de conviver com o doente mental e de ter uma palavra de respeito da natureza do que são suas necessidades, suas saídas, suas dificuldades. Acredito que uma das razões históricas da situação da doença mental no Brasil é a maneira como a comunidade científica se relacionou com a loucura (COSTA, 1987).

Não se trata simplesmente de criticar o saber ou o poder vigente. Importa sim, problematizar as técnicas e os dispositivos utilizados nos contextos institucionais que atuam sobre o comportamento dos indivíduos, tentando dirigílos, normatizá-los, modificá-los em sua maneira de ser para, finalmente, inscrevêlos nas estratégias de controle e disciplina. É justamente assim que os jogos de poder tentam governar o louco, objetivando-o como tal.

Contudo, acreditando como Foucault, que o poder se manifesta também como potência de vida, e que toda relação de poder implica em uma estratégia de luta, em uma insubmissão, pensamos que seja através da resistência mesma que os operadores da saúde poderão usar seu saber/poder com fins de questionar, provocar e, enfim, demarcar alvos para uma ação possível. De acordo com o autor, não basta apenas denunciar ou criticar a instituição, mas, “apresentá-la é a única maneira de evitar que outras instituições, com os mesmos objetivos e os mesmos efeitos, tomem seu lugar” (Foucault, 1981, p. 385). Para ele, o problema 
não é abolir as instituições psiquiátrico-penais ou as prisões, nem tampouco o de criar o 'hospital modelo’; o problema, sim, é “oferecer uma crítica do sistema que explique o processo pelo qual a sociedade atual impele para a margem uma parte da população” (Foucault, 1974, p. 296).

Por conseguinte, cabe a nós, operadores da saúde, o dever e o direito de interrogar os discursos acerca da verdade e, assim, poder exercer uma atitude crítica sobre ela. É através dessa resistência que será possível desembaraçar-se das práticas universais que tentam unificar as condutas em torno de um único modelo de subjetividade. Para isso, propomos uma reflexão acerca, não apenas da prática exercida pelo profissional 'psi' no campo mesmo do instituído, mas, principalmente quanto à possibilidade de transformação do seu olhar: do olhar de quem está dentro dos portões de ferro batido do MJ que, muitas vezes, parece muito semelhante àquele olhar carregado de pavor e repulsa de quem está no mundo de fora daqueles portões.

Assim, acreditamos que saídas poderão sempre ocorrer, tanto através da invenção de táticas e estratégias, 'bricolagens', golpes e astúcias - como nos ensina Michel de Certeau - quanto por intermédio da criação de linhas de fuga que fomentem a produção de um pensamento crítico, de uma visão reflexiva e de um livre questionamento a respeito das engrenagens produzidas no campo do instituído.

Faz-se imperioso abandonar as antigas e cronificadas soluções até então utilizadas e, em seu lugar, buscar novas práticas, novas maneiras de ser e de fazer, novas ações para se lidar com o cotidiano institucional, visando uma análise micropolítica que incite vigor e potência na lógica instituída, podendo-se, assim, produzir outros modos de subjetivação. Enfim, como afirmou Foucault em um de seus cursos, é preciso encontrar os pontos de resistência, através do quais as passagens se façam possíveis. Para isso, é preciso ousar!

O que não podemos mais suportar é continuar repetindo as antigas práticas jurídico-institucionais, nem tampouco permanecer atrelados a uma visão arcaica e obsoleta com relação à loucura. Acreditamos que exista um sujeito por trás da máscara nosológica conferida ao paciente inimputável e é preciso olhá-lo, considerando-o como alguém singular, como um sujeito de direito, capaz de respostas e atitudes que não aquelas preconizadas pela fatídica presunção de 
periculosidade. Desta feita, somos de opinião de que a singularidade presente em cada sujeito não pode ser reduzida ao simples vocábulo de 'louco-criminoso', carregado de preconceito e historicamente construído ao longo dos séculos.

Ao final desta dissertação, gostaríamos de acrescentar uma audaciosa e bem-humorada citação de Peter Pál Pelbart a respeito do trabalho do profissional 'psi' nas instituições:

A história mostra que também grandes revoluções às vezes começam em pequenos laboratórios, na cabeça e na prática de alguns poucos desvairados, na mais microscópica das agitações. Penso que é esse um dos nossos mais caros alentos. O trabalho diário e a mão na massa são sempre mais maçantes do que as belas palavras, mas não se deve, sob hipótese alguma, abdicar das belas palavras, assim como não se deve abdicar das belas histórias, nem dos belos gestos, muito menos das belas intervenções - o que não dizer das belas e desvairadas viagens. Sobretudo delas, que num trabalho deste tipo só se consegue fazer quando se está devidamente acompanhado, isto é, ladeado por uma equipe audaciosa e tresloucada [...], assumindo o risco de alçar vôos inusitados (PELBART, 1993, p. 25-26).

Desse modo, seguindo as ideias de Pelbart e acompanhando Michel Foucault, consideramos que o profissional atuante no campo 'psi' deve renunciar a sua missão profética e destruir as evidências e universalidades (Foucault, 1979 b), indicando e localizando brechas, pontos de força, e todas as formas possíveis de resistência: seja inventando contrapoderes ao poder instituído, seja, como afirma Heliana Conde Rodrigues (2006), “gerando campos de análise desnaturalizadores, tentando a ruptura com os cientificismos, profissionalismos e especialismos historicamente cristalizados,” ou, ainda, singularizando o estilo de viver e criando maneiras facultativas de ser. Acreditamos que, ao estabelecermos linhas de fuga que possibilitem a ruptura dos padrões institucionalizados, poderemos criar relações estratégicas que ampliem e diversifiquem as possibilidades de inventar novos modos de relação, consigo mesmo e com o outro. Segundo pensamos, o profissional 'psi' - e os demais trabalhadores na área de saúde - deve problematizar e tentar analisar como acontece o processo de sujeição, “o conjunto de obstáculos que antecedem à constituição dos sujeitos, [...] como, a partir de mecanismos sociais complexos que incidem sobre os corpos, foram-se dando historicamente mil formas de sujeição” (Bruni, 1989, p. 201), dentre elas, a do 'louco-criminoso'. 
Para Michel Foucault, faz parte desse entendimento, não apenas a aquisição de conhecimento científico sobre a loucura, mas, sobretudo, em adquirilo através do discurso daquele considerado como o próprio louco. No diálogo entre Michel Foucault e Gilles Deleuze em Os intelectuais e o poder, ambos refletem a respeito do fim do intelectual universal, do porta-voz dos direitos dos sujeitados, do cientista perito, do portador de saberes, “daquele que se coloca um pouco na frente para dizer a muda verdade de todos” (Foucault, 1979, p. 71). Para ambos, não existe maior indignidade do que se 'falar pelos outros'. José Carlos Bruni nos alerta para a lógica da produção do silêncio (dos sujeitados), como sendo o mais forte componente da situação de exclusão. E é, justamente, ao manter a perpetuação desse silêncio que o especialista impossibilita “de se considerar sujeito àquele a quem a fala é de antemão desfigurada ou negada” (Bruni, 1989, p. 201).

Tendo em conta as problematizações apresentadas nos últimos parágrafos, optamos por terminá-lo citando parte do primeiro prefácio da complexa obra de Michel Foucault, História da Loucura. ${ }^{67}$

Em meio do mundo sereno da doença mental, o homem moderno não se comunica mais com o louco; há de um lado o homem da razão que delega o médico para a loucura, autorizando, assim, a relação apenas por meio da universalidade abstrata da doença; há por outro lado, o homem da loucura que comunica com o outro somente pelo intermediário de uma razão completamente abstrata, que é ordem, coação física e moral, pressão anônima do grupo, exigência de conformidade. Linguagem comum não há; ou melhor, não há mais; a constituição da loucura como doença mental, no fim do século XVIII, comprova o diálogo rompido, dá a separação como já adquirida, e afunda no esquecimento todas essas palavras imperfeitas, sem sintaxe fixa, um pouco balbuciantes, nas quais se fazia a troca da loucura e da razão. A linguagem da psiquiatria, que é monólogo da razão sobre a loucura, só pode se estabelecer sobre tal silêncio.

Não quis fazer a história dessa linguagem, mas sim a arqueologia desse silêncio.

\footnotetext{
${ }^{67}$ Tal prefácio só figura integralmente na edição original, Folie et déraison. Histoire de la folie à l'âge classique (Paris, 1961). A partir de 1972, ele desaparece das três reedições.
} 
Referências bibliográficas

AGUIAR, K.F.; ROCHA, M.L. Pesquisa-Intervenção e a produção de novas análises. In: Revista Psicologia: ciência e profissão. Brasília, vol.23, nº 4, 2003.

ARAÚJO, M.P.; FERNANDES, T.M. O diálogo da história oral com a historiografia contemporânea. In: VISCARDI, C.M.R.; DELGADO, L.A.N. (Org.). História Oral: teoria, educação e sociedade. Juiz de Fora: UFJF, 2006.

ARANTES, E. Pensando a psicologia aplicada à justiça. In: Psicologia Jurídica no Brasil. GONÇALVES, H.; BRANDÃO, E. P. (Org.). Rio de Janeiro: NAU, 2011.

BALDEZ, M. Instituto de Processo: História, Sociedade e Direito. Palestra proferida no IBMEC: Rio de Janeiro, 2008.

BASAGliA, F. A Psiquiatria Alternativa. Contra o pessimismo da razão, o otimismo da prática. São Paulo: Brasil Debates, 1982.

BERARDINELLI, W. Noções de Biotypologia. Constituição, Temperamento, Caracter. Rio de Janeiro: Besnard Frères, 1932.

BEZERRA, B. Novas fronteiras da subjetivação. Café Filosófico. Gravado em Campinas em 03/07/2009. Disponível em: www.cpflcultura.com.br. Acesso em: 28 mai. 2011.

BIRMAN, J. Guerras psi. Dossiê Foucault. In: Cult - Revista Brasileira de Cultura. São Paulo, ano 14, 2011. Jogando com a Verdade. Uma Leitura de Foucault. In: PHYSIS: Revista Saúde Coletiva. Rio de Janeiro, 2002. Disponível em: www.scielo.br/pdf/physis/v12n2/a07v12n2.pdf. Acesso em: 05 jun. 2011.

BRASIL. Lei n ${ }^{\circ} 7.209$, de 11 de julho de 1984. Diário Oficial [da] República do Brasil, Poder Executivo, Brasília, DF, 13 jul. 1984.

BRITO e SOUTO, R. Medidas de segurança: Da Criminalização da Doença aos Limites do Poder de Punir. In: Crítica à Execução Penal. CARVALHO, Salo de. (Org.). Rio de Janeiro: Lumen Juris, 2007.

BRUNI, J. C. Foucault: O silêncio dos sujeitos. In: Revista Tempo Social. São Paulo, vol.1, 1989.

BURKE, P. A escrita da história. Novas perspectivas. São Paulo: UNESP, 1992.

CALDERON, P. Foucault, par lui-même. Documentário, 2003. 
CANDIOTTO, C. Foucault: uma história crítica da verdade. São Paulo: Revista Trans/Form/Ação, 2006. Disponível em: www.scielo.br/pdf/trans/v29n2/v29n2a06.pdf. Acesso em: 04 jun. 2011.

CARRARA, S. Crime e Loucura. Rio de Janeiro: EDUERJ, 1998.

CARVALHO, S. A criminologia na alcova: diálogo com Marquês de Sade. In: Boletim IBCCRIM. São Paulo, ano 15, nº 182, 2008.

O (Novo) Papel dos “Criminólogos” na Execução Penal: as alterações estabelecidas pela Lei 10.792/03. In: Crítica à Execução Penal. CARVALHO, Salo de. (Org.). Rio de Janeiro: Lumen Juris, 2007.

Penas e Garantias. Rio de Janeiro: Lumen Juris, 2008.

CASTEL, R. A ordem psiquiátrica: A idade de ouro do alienismo. Rio de Janeiro: Graal, 1978.

Os médicos e os juízes. In: Eu, Pierre Rivière, que degolei minha mãe, minha irmã e meu irmão. Rio de Janeiro: Graal, 1977.

CHARTIER R. Estratégias y Táticas. De Certeau y las Artes de hacer. In: Escribir las práticas. Buenos Aires: Manantial, 1996.

CÓDIGO Penal Brasileiro de 1940. Decreto-Lei n. ${ }^{\circ}$ 2.848, de 7 de dezembro de 1940.

CÓDIGO Penal Brasileiro de 1890.

CÓDIGO Penal Brasileiro de 1940. Decreto-Lei nº 7210 de 11 de Julho de 1984.

CONDÉ, M.L.L. Wittgenstein: Linguagem e Mundo. São Paulo: Annablume, 1998.

COSTA, J.F. Os interstícios da lei. In: Saúde mental e cidadania. São Paulo: Mandacaru, 1987.

COUTINHO, A.R. Repensando a questão da subjetividade. In: Redescrições da Psicanálise. Ensaios Pragmáticos. COSTA, Jurandir Freire. (Org.). Rio de Janeiro: Relume Dumará, 1994.

COUTINHO, A. O que nós, psicanalistas, podemos aprender com Foucault. In: Revista de Psicologia Clínica, Rio de Janeiro, vol.13, nº 1, 2001.

COUTINHO, E. O cinema-documentário e a escuta sensível da alteridade. Projeto História, São Paulo, nº 15, Abril/1997.

CRUZ, M.L. A inconstitucionalidade da medida de segurança face a periculosidade criminal. Dissertação de Mestrado, UniBrasil. Curitiba, 2009.

DE CERTEAU, M. A invenção do cotidiano 1. Artes de fazer. Rio de Janeiro: Vozes, 2005. 
DELEUZE, G. Foucault. São Paulo: Brasiliense, 2005.

Conversações. São Paulo: Editora 34, 1992.

ECHAVARREN, R. Foucault. Una introducción. Buenos Aires: Quadrata, 2011.

ENRIQUEZ, E; BLEGER, J; KAES, R. et al. A Instituição e as Instituições. Estudos Psicanalíticos. São Paulo: Casa do Psicólogo, 1991.

ERIBON, D. El arte de la insumisión. In: El infrequentable Michel Foucault. Renovación del pensamiento crítico. Buenos Aires: Letra Viva, 2004.

FERREIRA, A.B.H. Novo Dicionário da Língua Portuguesa. Rio de Janeiro: Nova Fronteira, 1975.

FERREIRA, M.M. História Oral e Tempo Presente. In: (Re) introduzindo a história oral no Brasil. MEIHY, J.C.S.B. (Org.). São Paulo: Xamã, 1996.

FIÚZA, G. Meu nome não é Johnny. Rio de Janeiro: Record, 2004.

FONSECA, M.A. Michel Foucault e o Direito. São Paulo: Max Limonad, 2002.

FRAGOSO, H. Sistema do duplo-binário: vida e morte. Artigo publicado nos "Studi in Memoria di Giacomo Delitala”, vol.III, Giùffre ed., 1984. Disponível em: www.fragoso.com.br/eng/arq_pdf/heleno_artigos/arquivo19.pdf. Acesso em: 14 mai. 2011.

FOUCAULT, M. Vigiar e Punir. Petrópolis: Vozes, 1977 a.

. História da loucura. São Paulo: Perspectiva, 2009 a.

. Doença Mental e Psicologia. Rio de Janeiro: Tempo Brasileiro, 1968.

. Os Anormais. São Paulo: Martins Fontes, 2001.

A loucura, a ausência da obra (1964). In: Ditos \& Escritos, vol. I. Rio de Janeiro: Forense Universitária, 2010 a.

A evolução da noção de "indivíduo perigoso" na psiquiatria legal do século XIX (1978 a). In: Ditos \& Escritos, vol. V. Rio de Janeiro: Forense Universitária, 2010 b.

- Mesa-redonda sobre a Expertise Psiquiátrica (1974). In: Ditos \& Escritos, vol. I. Rio de Janeiro: Forense Universitária, 2010 a.

. Eu, Pierre Rivière, que degolei minha mãe, minha irmã e meu irmão. Rio de Janeiro: Graal, 1977 b.

A verdade e as formas jurídicas. Rio de Janeiro: NAU, 2005. 
O sujeito e o poder. In: RABINOW, P.; DREYFUS, H. Uma Trajetória Filosófica. Para além do estruturalismo e da hermenêutica. Rio de Janeiro: Forense Universitária, 1995 a.

. O que são as luzes? In: Ditos \& Escritos, vol. II. Rio de Janeiro: Forense Universitária, 2010 c.

Poder e Saber (1977 c). In: Ditos \& Escritos, vol. IV. Rio de Janeiro: Forense Universitária, 2010 d. 1979. Poder-Corpo (1975). In: Microfísica do poder. Rio de Janeiro: Graal,

A vida dos homens infames (1977 d). In: Ditos \& Escritos, vol. IV. Rio de Janeiro: Forense Universitária, 2010 d.

Sobre a História da Sexualidade (1978 b). In: Microfísica do poder. Rio de Janeiro: Graal, 1979.

Verdade e Poder. In: Microfísica do poder. Rio de Janeiro: Graal, 1979 a.

. A ética do cuidado de si como prática de liberdade (1984 a). In: Ditos \& Escritos, vol. V. Rio de Janeiro: Forense Universitária, 2010 b.

O poder psiquiátrico. In: Resumo dos Cursos do Collège de France (1970-1982). Rio de Janeiro: Zahar, 1997.

. O governo de si e dos outros. In: Resumo dos Cursos do Collège de France (1983-1984). Rio de Janeiro: Zahar, 1997.

Não ao sexo rei. In: Microfísica do poder. Rio de Janeiro: Graal, 1979 b. Precisões sobre o Poder. Respostas a certas críticas (1978 c). In: Ditos \& Escritos, vol. IV. Rio de Janeiro: Forense Universitária, 2010 d.

Sobre a Prisão. In: Microfísica do poder. Rio de Janeiro: Graal, 1979 c.

La redéfinition du judiciable par Michel Foucault. In: Vacarme. Paris: Belles Lettres, n 29, 2004.

Em defesa da sociedade. São Paulo: Martins Fontes, 1999.

Foucault (1984 b). In: Ditos \& Escritos, vol. V. Rio de Janeiro: Forense Universitária, 2010 b.

O Grande Internamento (1972 a). In: Ditos \& Escritos, vol. I. Rio de Janeiro: Forense Universitária, 2010 a.

Sobre a genealogia da ética: uma revisão do trabalho. Michel Foucault entrevistado por Hubert L. Dreyfus e Paul Rabinow (1995). In: DREYFUS, H.; 
RABINOW, P.. Uma Trajetória Filosófica. Para além do estruturalismo e da hermenêutica. Rio de Janeiro: Forense Universitária, 1995 b.

A casa dos loucos. In: Microfísica do poder. Rio de Janeiro: Graal, 1979

e.

A ordem do discurso. São Paulo: Edições Loyola, 1996.

. Os intelectuais e o poder (1972 b). In: Microfísica do poder. Rio de Janeiro: Graal, 1979 f.

. “Omnes et Singulatim”: uma crítica da razão política (1981). In: Ditos \& Escritos, vol. IV. Rio de Janeiro: Forense Universitária, 2010 d.

. Prefácio (Folie et déraison - 1961). In: Ditos \& Escritos, vol. I. Rio de Janeiro: Forense Universitária, 2010 a.

. Qu'est-ce que la critique? [Critique et Aufklãrung], Bulletin de la Société française de philosophie, $84^{\circ}$ año, $n^{\circ} 2$, abril-junio de 1990, p. 36-63. In: ERIBON, D.. El infrequentable Michel Foucault. Renovación del pensamiento crítico. Buenos Aires: Letra Viva, 2004.

HOLlAndA, A.B. Novo Dicionário Aurélio da Língua Portuguesa. Rio de Janeiro: Nova Fronteira, 1975.

GABBAY, R.; VILHENA, J. O sujeito da loucura. In: Lat. Am. Journal of Fund. Psychopath. Online, v. 7, n. 2, p. 40-53, nov. 2010.

GOFFMAN, E. Manicômios, Prisões e Conventos. São Paulo: Perspectiva, 1974.

GUATTARI, F.; ROLNIK. Micropolítica. Cartografias do desejo. Petrópolis: Vozes, 1986.

IBRAHIM, E. Qual o novo endereço da medida de segurança? Palestra proferida na $51^{\text {a }}$ Reunião do Fórum Permanente de Execução Penal. Rio de Janeiro: Escola da Magistratura, 2000.

Previsibilidade de Comportamento do Apenado: uma missão totalmente impossível. In: Revista Brasileira de Ciências Criminais (IBCRIM) ano 7, n ${ }^{\circ}$ 28, de dezembro de 1999.

. Exame Criminológico. In: Execução Penal: estudos e pareceres. RAUTER, 9C. et al (Org.). Rio de Janeiro: Lumen Juris, 1995.

LAMPREIA, C. O percurso de uma vida dedicada ao conhecimento. Rio de Janeiro, 2002. Disponível em: www.psi.puc-rio.br/LampreiaPercurso.html. Acesso em: 26 mai. 2011.

LOBO, L. F. Um papel para o psicólogo hoje? In: Revista do Departamento de Psicologia da UFF, vol.9, n 2-3, 1997. 
LOPES, C. Esquizofrenia. Rio de Janeiro: Atlantida, 1934.

MACIEL, A. Foucault e a Clínica Psicanalítica. Curso ministrado na SPID (Org. COUTINHO, A.). Rio de Janeiro: 2009/2010/2011.

MACHADO, R. Ciência e Saber. A trajetória da arqueologia de Foucault. Rio de Janeiro: Graal, 1981. Graal, 1979.

Por uma genealogia do poder. In: Microfísica do poder. Rio de Janeiro:

MANDALARI, L. La Degenerazione nella pazzia e nella criminalità. Torini: Fratelli Bocca, 1901.

MARCÃO, R. Lei de Execução Penal. Anotada e Interpretada. Rio de Janeiro: Lumen Juris, 2006.

MARCONDES, D. Iniciação à História da Filosofia. Dos pré-socráticos a Wittgenstein. Rio de Janeiro: Zahar, 1997.

Filosofia, Linguagem e Comunicação. São Paulo: Cortez, 2000.

MARTINS, J.S. A sociedade vista do abismo: novos estudos sobre a exclusão, pobreza e classes sociais. Petrópolis: Vozes, 2002.

MATTOS, V. Trem de doido: o direito penal \& a psiquiatria de mãos dadas. Belo Horizonte: UNA, 1999.

NARDI, H.C.; SILVA, R.N. Ética e Subjetivação: as técnicas de si e os jogos de verdade contemp/orâneos. In: GUARESCHI, N.M.F.; HÜNING, S.M. et al. Foucault e a Psicologia. Porto Alegre: EDIPUCRS, 2009.

PASSETI, E. Loucura e transtornos: políticas normalizadoras. In: O mesmo e o outro. 50 anos de História da loucura. VII Colóquio Internacional Michel Foucault. São Paulo: PUC/SP, 2011.

PELBART, P.P. A Nau do Tempo-Rei. 7 Ensaios sobre o Tempo da Loucura. Rio de Janeiro: Imago, 1993.

PERELMUTTER, D. Historia Oral, Memória e Subjetividade. In: $1^{\circ}$ Encontro das Ações Educativas em Museus da cidade de São Paulo. São Paulo, 2006.

A história oral e a trama sensível da subjetividade. Dissertação de Mestrado em Psicologia Clínica. Pontifícia Universidade de São Paulo, 1997 (mimeo).

POLLAK, M. Memória, esquecimento, silêncio. In: Estudos Históricos. Rio de Janeiro, vol. 2, nº 3, 1989.

A história oral e a trama sensível da subjetividade. Dissertação de Mestrado em Psicologia Clínica. PUC/São Paulo: 1997. 
2002.

Biopolítica e Biopotência no coração do Império. In: Multitudes, nº 9,

PORTELLI, A. A Filosofia e os Fatos. Narração, interpretação e significado nas memórias e nas fontes orais. In: Revista Tempo, Rio de Janeiro, vol. 1, $\mathrm{n}^{0} 2$, 1996.

O que faz a história oral diferente. In: Projeto História, São Paulo, $\mathrm{n}^{0}$ 14, fevereiro/1997a.

RAUTER, C. Criminologia e subjetividade no Brasil. Rio de Janeiro: Revan, 2003.

. Manicômios, Prisões, Reformas e Neoliberalismo. In: Discursos sediciosos. Rio de Janeiro, vol. 1, nº 3, 1997.

ROCHA, S.P.V. Tornar-se quem se é: educação como formação, educação como transformação. In: FEITOSA, C. (Org.). Nietzsche e os gregos. São Paulo: DP\&A, 2006.

RODRIGUES, H.B.C. No rastro dos "Cavalos do Diabo". Tese de Doutoramento em Psicologia, USP, 2002.

Sejamos realistas, tentemos o impossível! Desencaminhando a Psicologia através da Análise Institucional. In: JACÓ-VILELA A. M.; FERREIRA A. A. L.; PORTUGAL F. T. (Org.). História da psicologia - rumos e percursos. Rio de Janeiro: Nau Editora, 2006.

ROSE, N. Como se deve fazer a história do eu? In: Physis: Revista de Saúde Coletiva. Rio de Janeiro, vol.20, n ${ }^{\circ}$ 1, 2010.

SALLES, W. Relembrando Alberto Granado. Artigo publicado no Jornal O Globo em 27/03/2011.

SZASZ, T. A fabricação da loucura. Rio de Janeiro: Zahar, 1978.

Ideologia e doença mental. Rio de Janeiro: Zahar, 1980.

A Escravidão Psiquiátrica. Rio de Janeiro: Nova Fronteira, 1986.

THOMPSON, A.F.G. A questão penitenciária. Petrópolis: Vozes, 1976.

THOMPSON, P. A voz do passado. Rio de Janeiro: Paz e Terra, 1992.

VEYNE, P. Foucault revoluciona a história. In: Como se escreve a história. Brasília: UNB, 1990.

. Un arqueólogo escéptico. In: El Infrecuentable Michel Foucault. Buenos Aires: Letra Viva, 2004.

. O último Foucault e sua moral (1985). Disponível em: dc220.4shared.com/doc/pJblK-_I/preview.html. Acesso em: 04 mai. 2012. 
Tradução de Le dernier Foucault et sa morale em Critique, Paris, Vol. XLIL, no 471-472, p.

933-941, 1985, por Wanderson Flor do Nascimento.

VILELA, E. Corpos inabitáveis, errância, filosofia e memória. In: Habitantes de Babel. Políticas e poéticas da diferença. Belo Horizonte: Autêntica, 2001.

ZAFFARONI, E.R. Criminologia: Aproximación desde un margen. Bogotá: Temis, 1993. 